Nevada

Environmental

Restoration

Project

\title{
Corrective Action Investigation Plan for Corrective Action Unit 190: Contaminated Waste Sites Nevada Test Site, Nevada
}

Controlled Copy No.:

Revision No.: 0

December 2006

Approved for public release; further dissemination unlimited.

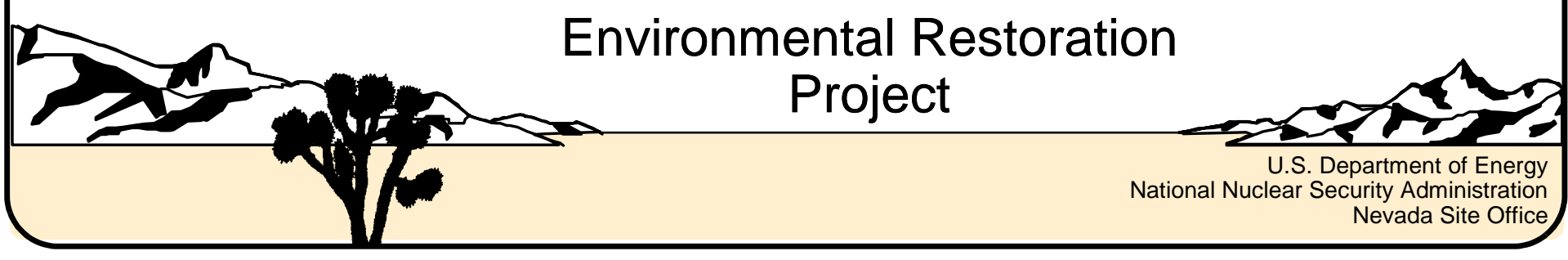


Available for sale to the public from:

\section{U.S. Department of Commerce}

National Technical Information Service

5285 Port Royal Road

Springfield, VA 22161

Phone: 800.553.6847

Fax: 703.605.6900

Email: orders@ntis.gov

Online ordering: http://www.ntis.gov/ordering.htm

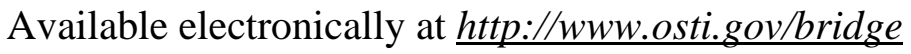

Available for a processing fee to U.S. Department of Energy and its contractors, in paper, from:

\section{U.S. Department of Energy}

Office of Scientific and Technical Information

P.O. Box 62

Oak Ridge, TN 37831-0062

Phone: 865.576.8401

Fax: 865.576.5728

Email: reports@adonis.osti.gov

Reference herein to any specific commercial product, process, or service by trade name, trademark, manufacturer, or otherwise, does not necessarily constitute or imply its endorsement, recommendation, or favoring by the United States Government or any agency thereof or its contractors or subcontractors. 


\title{
CORRECTIVE ACTION INVESTIGATION PLAN FOR CORRECTIVE ACTION UNIT 190: CONTAMINATED WASTE SITES NEVADA TEST SITE, NEVADA
}

\author{
U.S. Department of Energy \\ National Nuclear Security Administration \\ Nevada Site Office \\ Las Vegas, Nevada
}

Controlled Copy No.:

Revision No.: 0

December 2006

Approved for public release; further dissemination unlimited. 


\section{CORRECTIVE ACTION INVESTIGATION PLAN FOR}

CORRECTIVE ACTION UNIT 190:

CONTAMINATED WASTE SITES

NEVADA TEST SITE, NEVADA

Approved by: $\begin{aligned} & \text { Approved signature } \\ & \begin{array}{l}\text { Kevin Cabble } \\ \text { Federal Sub-Project Director } \\ \text { Industrial Sites Sub-Project }\end{array}\end{aligned}$

\footnotetext{
Approved by: Approved signature

Date: $12-11-06$

John B. Jones

Acting Federal Project Director

Environmental Restoration Project
} 


\section{Table of Contents}

List of Figures. . . . . . . . . . . . . . . . . . . . . .

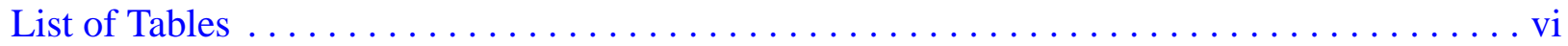

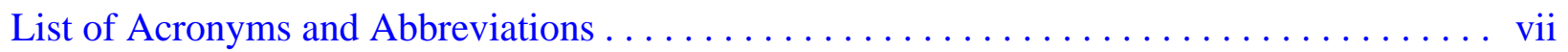

Executive Summary . . . . . . . . . . . . . . . . . . . . . . ES-1

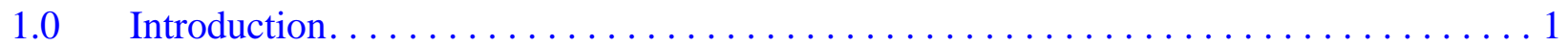

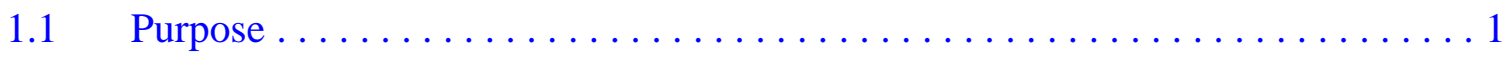

1.1.1 Corrective Action Unit 190 History and Description. . . . . . . . . . 3

1.1.2 Data Quality Objective Summary ..................... 3

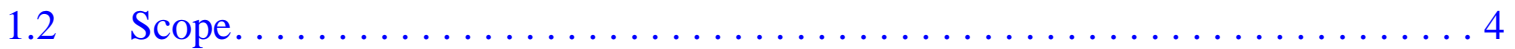

1.3 Corrective Action Investigation Plan Contents $\ldots \ldots \ldots \ldots \ldots \ldots \ldots$

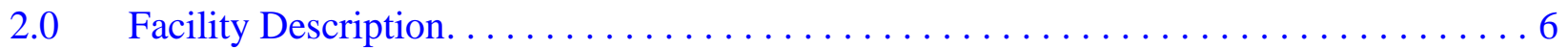

$2.1 \quad$ Physical Setting. . . . . . . . . . . . . . . . . . . . 6

2.2 Operational History. . . . . . . . . . . . . . . . . . . . 7

2.2.1 Corrective Action Site 11-02-01, Underground Centrifuge . . . . . . . . . 8

2.2.2 Corrective Action Site 11-02-02, Drain Lines and Outfall . . . . . . . . 8

2.2.3 Corrective Action Site 11-59-01, Tweezer Facility Septic System . . . . 9

2.2.4 Corrective Action Site 14-23-01, LTU-6 Test Area. . . . . . . . . . . . . . . 9

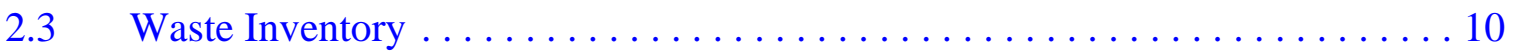

2.3.1 Corrective Action Site 11-02-01, Underground Centrifuge. . . . . . . . . 10

2.3.2 Corrective Action Site 11-02-02, Drain Lines and Outfall . . . . . . . . . 10

2.3.3 Corrective Action Site 11-59-01, Tweezer Facility Septic System . . . . 11

2.3.4 Corrective Action Site 14-23-01, LTU-6 Test Area. . . . . . . . . . . . . 11

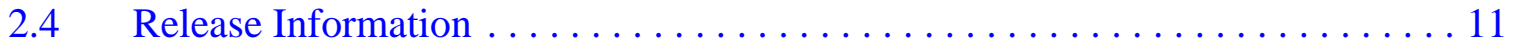

2.4.1 Corrective Action Site 11-02-01, Underground Centrifuge . . . . . . . . . 11

2.4.2 Corrective Action Site 11-02-02, Drain Lines and Outfall . . . . . . . . . 12

2.4.3 Corrective Action Site 11-59-01, Tweezer Facility Septic System . . . . 12

2.4.4 Corrective Action Site 14-23-01, LTU-6 Test Area. . . . . . . . . . . . . . . 12

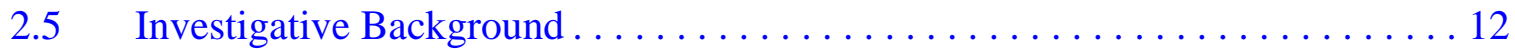

2.5.1 Corrective Action Site 11-02-01, Underground Centrifuge . . . . . . . . . 12

2.5.2 Corrective Action Site 11-02-02, Drain Lines and Outfall . . . . . . . . . 13

2.5.3 Corrective Action Site 11-59-01, Tweezer Facility Septic System . . . . 13

2.5.4 Corrective Action Site 14-23-01, LTU-6 Test Area. . . . . . . . . . . . . . 13

3.0 Objectives ................................. 14

3.1 Conceptual Site Model . . . . . . . . . . . . . . . . . . . . 14

3.1.1 Land Use and Exposure Scenarios . . . . . . . . . . . . . . 14

3.1.2 Contaminant Sources . . . . . . . . . . . . . . . . . . . . . . 17 


\section{Table of Contents (Continued)}

3.1.3 Release Mechanisms . . . . . . . . . . . . . . . . . 17

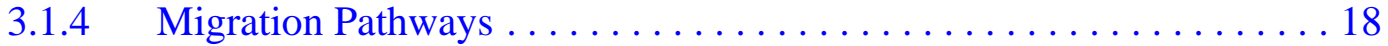

3.1.5 Exposure Points ............................. 19

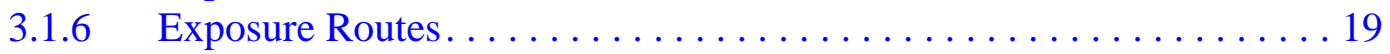

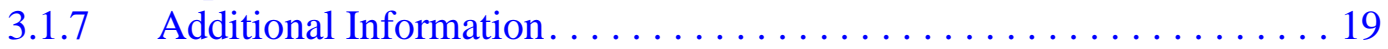

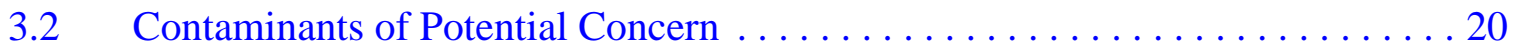

3.3 Preliminary Action Levels . . . . . . . . . . . . . . . . . . . . 23

3.3.1 Chemical PALs. . . . . . . . . . . . . . . . . . . . 25

3.3.2 Total Petroleum Hydrocarbon PALs . . . . . . . . . . . . . . . 25

3.3.3 Radionuclide PALs. . . . . . . . . . . . . . . . . . . . . . . . . 25

3.4 Data Quality Objective Process Discussion $\ldots \ldots \ldots \ldots \ldots \ldots \ldots \ldots \ldots \ldots \ldots \ldots \ldots$

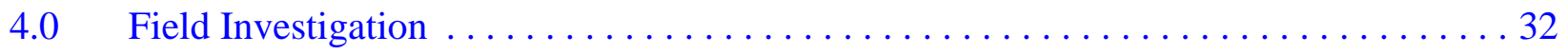

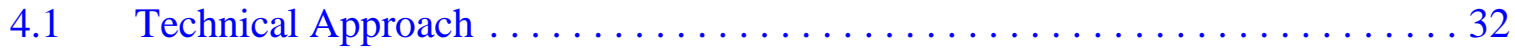

$4.2 \quad$ Field Activities . . . . . . . . . . . . . . . . . . . . 32

4.2.1 Site Preparation Activities . . . . . . . . . . . . . . . . . . 33

4.2 .2 Sample Location Selection. . . . . . . . . . . . . . . . . 33

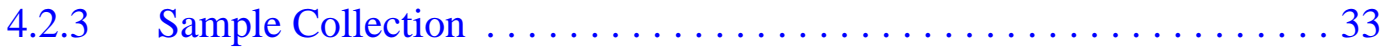

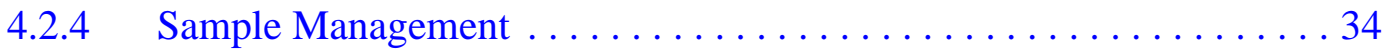

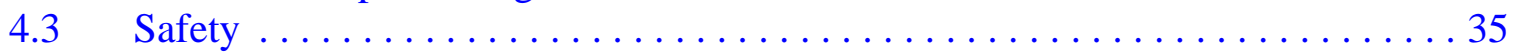

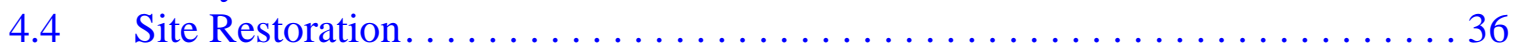

$5.0 \quad$ Waste Management. . . . . . . . . . . . . . . . . . . . . 37

$5.1 \quad$ Waste Minimization . . . . . . . . . . . . . . . . . . . . 37

5.2 Potential Waste Streams . . . . . . . . . . . . . . . . . . . 38

5.3 Investigation-Derived Waste Management $\ldots \ldots \ldots \ldots \ldots \ldots \ldots \ldots \ldots \ldots$

5.3 .1 Sanitary Waste . . . . . . . . . . . . . . . . . . 38

5.3.2 Low-Level Radioactive Waste . . . . . . . . . . . . . . . . . . . . . . . . 40

5.3 .3 Hazardous Waste . . . . . . . . . . . . . . . . . . 40

5.3 .4 Hydrocarbon Waste . . . . . . . . . . . . . . . . . 41

5.3 .5 Mixed Low-Level Waste . . . . . . . . . . . . . . . . . . 41

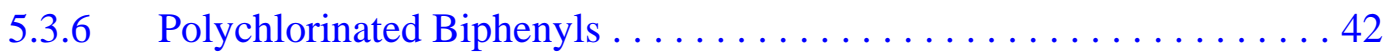

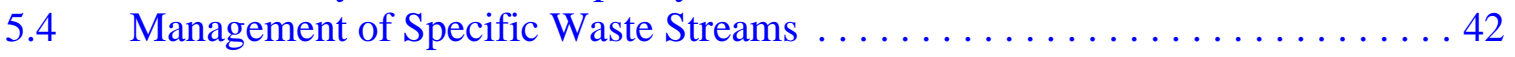

5.4 .1 Personal Protective Equipment. . . . . . . . . . . . . . . . . 42

5.4.2 Management of Decontamination Rinsate .................. 43

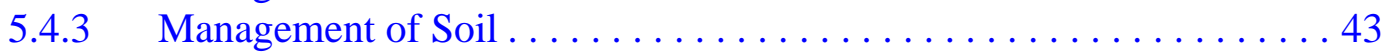

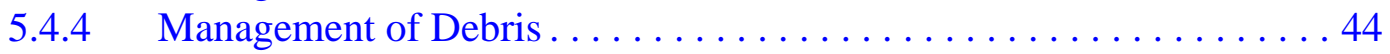

5.4 .5 Field-Screening Waste . . . . . . . . . . . . . . . 44

6.0 Quality Assurance/Quality Control . . . . . . . . . . . . . . . . . . . 45

6.1 Quality Control Sampling Activities ................... 45 


\section{Table of Contents (Continued)}

$6.2 \quad$ Laboratory/Analytical Quality Assurance $\ldots \ldots \ldots \ldots \ldots \ldots \ldots \ldots . \ldots 45$

$6.2 .1 \quad$ Data Validation................................. 46

6.2 .2 Data Quality Indicators....................... 46

6.2.3 Precision.................................. 47

6.2.4 Accuracy...................................... 49

6.2.5 Representativeness ............................. 49

6.2.6 Completeness . . . . . . . . . . . . . . . . . . . . . . . . . 50

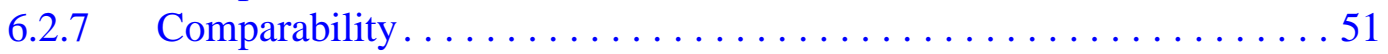

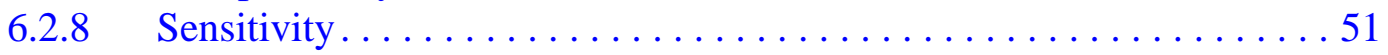

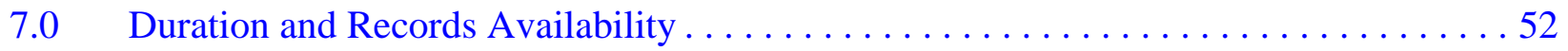

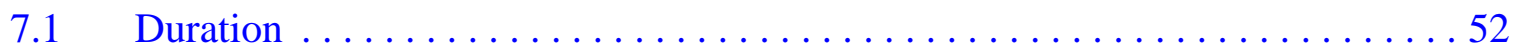

$7.2 \quad$ Records Availability ................................. 52

$8.0 \quad$ References...................................... 53

\section{Appendix A - Data Quality Objectives}

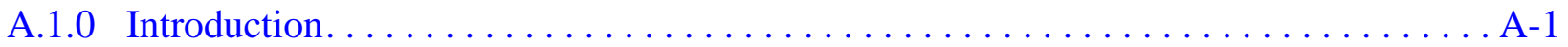

A.2.0 Background Information. $\ldots \ldots \ldots \ldots \ldots \ldots \ldots \ldots \ldots \ldots \ldots \ldots \ldots \ldots \ldots \ldots \ldots \ldots \ldots$

A.2.1 Corrective Action Site 11-02-01, Underground Centrifuge ............. A-3

A.2.2 Corrective Action Site 11-02-02, Drain Lines and Outfall. ............. A-7

A.2.3 Corrective Action Site 11-59-01, Tweezer Facility Septic System . . . . . . . . . A-9

A.2.4 Corrective Action Site 14-23-01, LTU-6 Test Area . . . . . . . . . . . . . A-11

A.2.5 National Environmental Policy Act ................. A-16

A.3.0 Step 1 - State the Problem............................... A-17

A.3.1 Planning Team Members . . . . . . . . . . . . . . . . . . . . . A

A.3.2 Conceptual Site Model ............................ A-17

A.3.2.1 Contaminant Release ......................... A-18

A.3.2.2 Potential Contaminants....................... A-19

A.3.2.3 Contaminant Characteristics.................... A-21

A.3.2.4 Site Characteristics........................ A-23

A.3.2.5 Migration Pathways and Transport Mechanisms............ A-23

A.3.2.6 Exposure Scenarios ......................... A-24

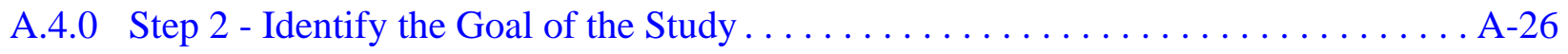

A.4.1 Decision Statements . . . . . . . . . . . . . . . . . . . . . A-26

A.4.2 Alternative Actions to the Decisions $\ldots \ldots \ldots \ldots \ldots \ldots \ldots \ldots \ldots \ldots$ A-27

A.4.2.1 Alternative Actions to Decision I. . . . . . . . . . . . A-27 


\section{Table of Contents (Continued)}

A.4.2.2 Alternative Actions to Decision II . . . . . . . . . . . . . . A-27

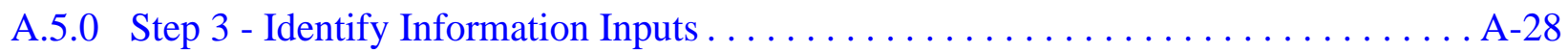

A.5.1 Information Needs . . . . . . . . . . . . . . . . . . . . . . . . . A-28

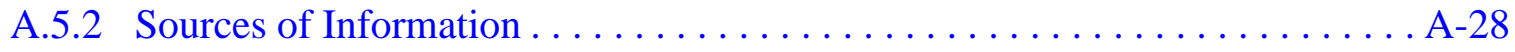

A.5.2.1 Sample Locations ......................... A-29

A.6.0 Step 4 - Define the Boundaries of the Study $\ldots \ldots \ldots \ldots \ldots \ldots \ldots \ldots \ldots$ A-32

A.6.1 Target Populations of Interest. . . . . . . . . . . . . . . . . . A-32

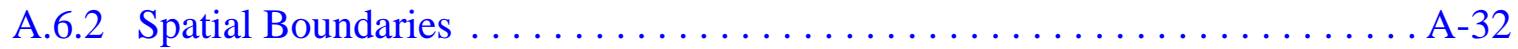

A.6.3 Practical Constraints ............................. A-33

A.6.4 Define the Sampling Units $\ldots \ldots \ldots \ldots \ldots \ldots \ldots \ldots \ldots \ldots \ldots \ldots \ldots \ldots \ldots \ldots$

A.7.0 Step 5 - Develop the Analytic Approach ......................... A-34

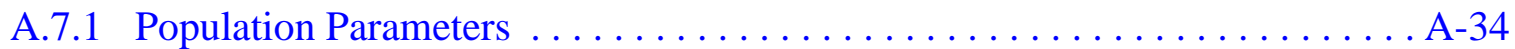

A.7.2 Action Levels ................................ A-34

A.7.2.1 Chemical PALs............................ A-35

A.7.2.2 Total Petroleum Hydrocarbon PALs . . . . . . . . . . . . . A-36

A.7.2.3 Radionuclide PALs......................... A-36

A.7.3 Decision Rules . . . . . . . . . . . . . . . . . . . . . . . A

A.8.0 Step 6 - Specify Performance or Acceptance Criteria . . . . . . . . . . . . . . . . A-38

A.8.1 Decision Hypotheses. . . . . . . . . . . . . . . . . . . . . . . . A-38

A.8.2 False Negative Decision Error $\ldots \ldots \ldots \ldots \ldots \ldots \ldots \ldots \ldots \ldots \ldots \ldots$ A-38

A.8.3 False Positive Decision Error $\ldots \ldots \ldots \ldots \ldots \ldots \ldots \ldots \ldots \ldots \ldots \ldots \ldots \ldots$

A.9.0 Step 7 - Develop the Plan for Obtaining Data $\ldots \ldots \ldots \ldots \ldots \ldots \ldots \ldots$ A-42

A.9.1 Judgmental Sampling . . . . . . . . . . . . . . . . . . . . . . A-42

A.9.2 Decision II Sampling . . . . . . . . . . . . . . . . . . . . . . A-43

A.9.3 Corrective Action Site 11-02-01, Underground Centrifuge . . . . . . . . . . . A-43

A.9.4 Corrective Action Site 11-02-02, Drain Lines and Outfall. . . . . . . . . . . A-43

A.9.5 Corrective Action Site 11-59-01, Tweezer Facility Septic System . . . . . . . . A-44

A.9.6 Corrective Action Site 14-23-01, LTU-6 Test Area. . . . . . . . . . . . . . . . A-45

A.10.0 References. .................................... A-48

\section{Appendix B - Project Organization}

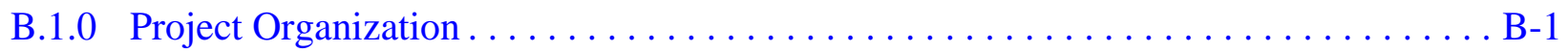




\section{List of Figures}

Number

Title

Page

1-1 Nevada Test Site Map with CAU 190 CAS Locations . . . . . . . . . . . 2

3-1 Conceptual Site Model Diagram . . . . . . . . . . . . . . . . . . . . 15

3-2 Corrective Action Unit 190 Conceptual Site Model . . . . . . . . . . . . 16

3-3 Risk-Based Corrective Action Decision Process $\ldots \ldots \ldots \ldots \ldots \ldots \ldots \ldots$

A.2-1 Corrective Action Unit 190, CAS Location Map . . . . . . . . . . . . . A-4

A.2-2 Corrective Action Unit 190 CASs Within the Tweezer Facility . . . . . . . . . . . A-5

A.2-3 Site Sketch of CAS 11-02-01, Underground Centrifuge . . . . . . . . . . . A-6

A.2-4 Site Sketch of CAS 11-02-02, Drain Lines and Outfall $\ldots \ldots \ldots \ldots \ldots \ldots \ldots$ A-8

A.2-5 Site Sketch of CAS 11-59-01, Tweezer Facility Septic System . . . . . . . . . A-10

A.2-6 Radiological Survey of CAS 14-23-01, LTU-6 Test Area . . . . . . . . . . . . A A-15

A.3-1 Corrective Action Unit 190 Conceptual Site Model . . . . . . . . . . . . . . A-20

A.9-1 Corrective Action Site 14-23-01 Features. . . . . . . . . . . . . . . . . . . A-47 


\section{List of Tables}

Number

Title

Page

3-1 Analytical Program (Includes Waste Characterization Analyses). ............ 20

3-2 Targeted Contaminant for CAU $190 \ldots \ldots \ldots \ldots \ldots \ldots \ldots \ldots \ldots \ldots \ldots \ldots \ldots$

3-3 Constituents Reported by Analytical Methods ....................... 22

3-4 Analytical Requirements for Radionuclides for CAU $190 \ldots \ldots \ldots \ldots \ldots \ldots$

3-5 Analytical Requirements for Chemical COPCs for CAU $190 \ldots \ldots \ldots \ldots \ldots$

5-1 Waste Management Regulations and Requirements ................... 39

6-1 Laboratory and Analytical Performance Criteria

for CAU 190 Data Quality Indicators . . . . . . . . . . . . . . . . . . . 47

7-1 Corrective Action Investigation Activity Durations $\ldots \ldots \ldots \ldots \ldots \ldots$

A.2-1 Summary of Radiological Survey Data Obtained at LTU-6 Test Area

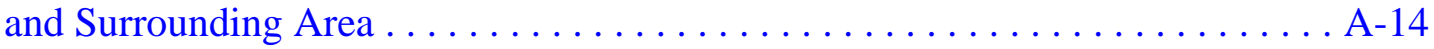

A.2-2 Summary of Confidence Limits for the Radiological Survey Data at LTU-6 Test Area .................................. A-14

A.3-1 Conceptual Site Model Description of Elements for Each CAS in CAU 190 .. A-19

A.3-2 Analytical Program (Includes Waste Characterization Analyses). . . . . . . . A-22

A.3-3 Targeted Contaminants for CAU $190 \ldots \ldots \ldots \ldots \ldots \ldots \ldots \ldots \ldots$ A-23

A.3-4 Land-Use and Exposure Scenarios $\ldots \ldots \ldots \ldots \ldots \ldots \ldots \ldots \ldots \ldots$ A-25

A.6-1 Spatial Boundaries of CAU 190 CASs $\ldots \ldots \ldots \ldots \ldots \ldots \ldots \ldots \ldots$ A-32

A.6-2 Practical Constraints for the CAU 190 Field Investigation............. A-33 


\section{List of Acronyms and Abbreviations}

ASTM American Society for Testing and Materials

bgs Below ground surface

CADD Corrective Action Decision Document

CAI Corrective Action Investigation

CAIP Corrective Action Investigation Plan

CAS Corrective Action Site

CAU Corrective Action Unit

CERCLA Comprehensive Environmental Resource Conservation and Liability Act

CFR $\quad$ Code of Federal Regulations

COC Contaminant of concern

COPC Contaminant of potential concern

cps Counts per second

CSM Conceptual site model

DoD U.S. Department of Defense

DOE U.S. Department of Energy

DOT U.S. Department of Transportation

DQI Data quality indicator

DQO Data quality objective

DRI Desert Research Institute

EPA U.S. Environmental Protection Agency

EQL Estimated quantitation limit

FAL Final action level

FADL Field Activity Daily Log

FFACO Federal Facility Agreement and Consent Order 


\section{Acronyms and Abbreviations (Continued)}

$\begin{array}{ll}\text { ft } & \text { Foot } \\ \text { FWP } & \text { Field Work Permit } \\ \text { GPS } & \text { Global Positioning System } \\ \text { HASP } & \text { Health and Safety Plan } \\ \text { HEST } & \text { High-Explosive Simulation Test } \\ \text { HWAA } & \text { Hazardous waste accumulation area } \\ \text { IDW } & \text { Investigation-derived waste } \\ \text { in. } & \text { Inch } \\ \text { IS HASP } & \text { Industrial Sites Health and Safety Plan } \\ \text { ISMS } & \text { Integrated Safety Management System } \\ \text { LCS } & \text { Laboratory control sample } \\ \text { LCSD } & \text { Laboratory control sample duplicate } \\ \text { m } & \text { Meter } \\ \text { MDC } & \text { Minimum detectable concentration } \\ \text { NDg/kg } & \text { Milligrams per kilogram } \\ \text { mg/L } & \text { Milligrams per liter } \\ \text { Ni } & \text { Mile } \\ \text { MS } & \text { Matrix spike } \\ \text { Novada Administrative Code }\end{array}$




\section{Acronyms and Abbreviations (Continued)}

\begin{tabular}{|c|c|}
\hline NEPA & National Environmental Policy Act \\
\hline NNSA/NSO & $\begin{array}{l}\text { U.S. Department of Energy, National Nuclear Security Administration } \\
\text { Nevada Site Office }\end{array}$ \\
\hline NRS & Nevada Revised Statutes \\
\hline NSTec & National Security Technologies, LLC \\
\hline NTS & Nevada Test Site \\
\hline NTSWAC & Nevada Test Site Waste Acceptance Criteria \\
\hline NV/YMP & Nevada Yucca Mountain Project \\
\hline PAL & Preliminary action level \\
\hline PCB & Polychlorinated biphenyl \\
\hline $\mathrm{pCi} / \mathrm{g}$ & Picocuries per gram \\
\hline $\mathrm{pCi} / \mathrm{L}$ & Picocuries per liter \\
\hline POC & Performance Objective for the Certification of Nonradioactive Hazardous Waste \\
\hline PPE & Personal protective equipment \\
\hline ppm & Parts per million \\
\hline PRG & Preliminary remediation goal \\
\hline QA & Quality assurance \\
\hline QAPP & Quality Assurance Project Plan \\
\hline QC & Quality control \\
\hline RadCon & Radiological Control \\
\hline RBCA & Risk-based corrective action \\
\hline RBSL & Risk-based screening level \\
\hline RCA & Radiologically controlled area \\
\hline RCRA & Resource Conservation and Recovery Act \\
\hline
\end{tabular}




\section{Acronyms and Abbreviations (Continued)}

$\begin{array}{ll}\text { REECo } & \text { Reynolds Electrical \& Engineering Co., Inc. } \\ \text { RESRAD } & \text { Residual Radioactive } \\ \text { RL } & \text { Reporting limit } \\ \text { RMA } & \text { Radioactive material area } \\ \text { RPD } & \text { Relative percent difference } \\ \text { SDWS } & \text { Safe Drinking Water Standards } \\ \text { SNJV } & \text { Stoller-Navarro Joint Venture } \\ \text { SS } & \text { Site Supervisor } \\ \text { SSHASP } & \text { Site-Specific Health and Safety Plan } \\ \text { SSTL } & \text { Site-specific target level } \\ \text { SVOC } & \text { Semivolatile organic compound } \\ \text { TCLP } & \text { Toxicity Characteristic Leaching Procedure } \\ \text { TM } & \text { Task Manager } \\ \text { TPH } & \text { Total petroleum hydrocarbons } \\ \text { TSCA } & \text { Toxic Substance Control Act } \\ \text { UGTA } & \text { Underground Test Area } \\ \text { USGS } & \text { U.S. Geological Survey } \\ \text { UST } & \text { Underground storage tank } \\ \text { VOC } & \text { Volatile organic compound } \\ \text { \%R } & \\ \text { RScent recovery }\end{array}$




\section{Executive Summary}

Corrective Action Unit (CAU) 190 is located in Areas 11 and 14 of the Nevada Test Site, which is 65 miles northwest of Las Vegas, Nevada. Corrective Action Unit 190 is comprised of the four Corrective Action Sites (CASs) listed below:

- 11-02-01, Underground Centrifuge

- 11-02-02, Drain Lines and Outfall

- 11-59-01, Tweezer Facility Septic System

- 14-23-01, LTU-6 Test Area

These sites are being investigated because existing information is insufficient on the nature and extent of potential contamination to evaluate and recommend corrective action alternatives. Additional information will be obtained before evaluating corrective action alternatives and selecting the appropriate corrective action for each CAS by conducting a corrective action investigation (CAI). The results of the field investigation will support a defensible evaluation of viable corrective action alternatives that will be presented in the Corrective Action Decision Document.

The sites will be investigated based on the data quality objectives (DQOs) developed on August 24, 2006, by representatives of the Nevada Division of Environmental Protection; U.S. Department of Energy, National Nuclear Security Administration Nevada Site Office; Stoller-Navarro Joint Venture, and National Security Technologies, LLC. The DQO process was used to identify and define the type, amount, and quality of data needed to develop and evaluate appropriate corrective actions for CAU 190.

The scope of the CAU 190 CAI includes the following activities:

- Move surface debris and/or materials, as needed, to facilitate sampling.

- Conduct radiological and geophysical surveys.

- $\quad$ Perform field screening.

- Collect and submit environmental samples for laboratory analysis to determine whether contaminants of concern (COCs) are present. 
- If COCs are present, collect additional step-out samples to define the lateral and vertical extent of the contamination.

- Collect samples of source material, if present, to determine the potential for a release.

- Collect samples of investigation-derived waste, as needed, for waste management and minimization purposes.

- Collect quality control samples.

This Corrective Action Investigation Document (CAIP) has been developed in accordance with the Federal Facility Agreement and Consent Order (FFACO) agreed to by the State of Nevada, U.S. Department of Energy, and U.S. Department of Defense. Under the FFACO, this CAIP will be submitted to the Nevada Division of Environmental Protection for approval. Field work will be conducted following approval. 


\subsection{Introduction}

This Corrective Action Investigation Plan (CAIP) contains project-specific information including facility descriptions, environmental sample collection objectives, and criteria for conducting site investigation activities at Corrective Action Unit (CAU) 190: Contaminated Waste Sites, Nevada Test Site (NTS), Nevada.

This CAIP has been developed in accordance with the Federal Facility Agreement and Consent Order (FFACO) (1996) that was agreed to by the State of Nevada, the U.S. Department of Energy (DOE), and the U.S. Department of Defense (DoD).

Corrective Action Unit 190 is located in Areas 11 and 14 of the NTS, which is approximately 65 miles (mi) northwest of Las Vegas, Nevada (Figure 1-1). Corrective Action Unit 190 is comprised of the four corrective action sites (CASs) shown on Figure 1-1 and listed below:

- 11-02-01, Underground Centrifuge

- 11-02-02, Drain Lines and Outfall

- 11-59-01, Tweezer Facility Septic System

- 14-23-01, LTU-6 Test Area

The Corrective Action Investigation (CAI) will include field inspections, radiological surveys, geophysical surveys, sampling of environmental media, analysis of samples, and assessment of investigation results, where appropriate. Data will be obtained to support corrective action alternative evaluations and waste management decisions.

\subsection{Purpose}

The CASs in CAU 190 are being investigated because hazardous and/or radioactive constituents may be present in concentrations that could potentially pose a threat to human health and the environment. Existing information on the nature and extent of potential contamination is insufficient to evaluate and recommend corrective action alternatives for the CASs. Additional information will be generated by conducting a CAI before evaluating and selecting corrective action alternatives. 


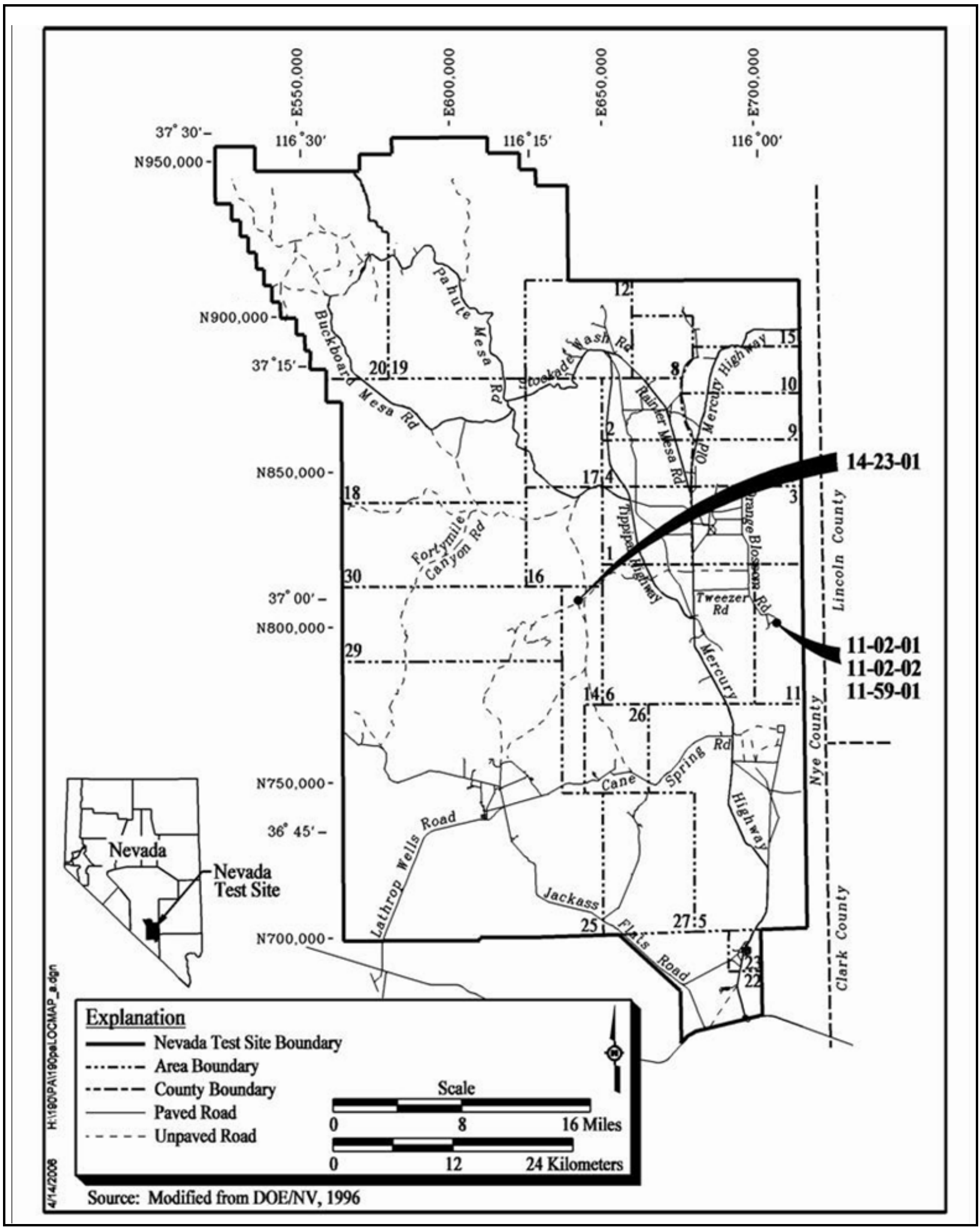

Figure 1-1

Nevada Test Site Map with CAU 190 CAS Locations 


\subsubsection{Corrective Action Unit 190 History and Description}

Corrective Action Unit 190, Contaminated Waste Sites, consists of four inactive sites. Three are located within the Tweezer Facility in Area 11 and consist of an underground centrifuge, drain lines and outfall, and a septic system and leachfield. The fourth site is at the LTU-6 Test Area in the northern part of Area 14, near the Mine Mountain Road and Mid Valley Road (Saddle Mountain Road) junction. This site consists of potentially contaminated soil from the ejected debris from MX missile testing.

The CAU 190 sites were used to support nuclear weapons testing and MX missile testing during the 1960s through the 1980s. Operational histories for each CAU 190 CAS are detailed in Section 2.2.

\subsubsection{Data Quality Objective Summary}

The sites will be investigated based on data quality objectives (DQOs) developed by representatives of the Nevada Division of Environmental Protection (NDEP); DOE, National Nuclear Security Administration Nevada Site Office (NNSA/NSO); Stoller-Navarro Joint Venture (SNJV); and National Security Technologies, LLC (NSTec). The DQOs are used to identify and define the type, amount, and quality of data needed to develop and evaluate appropriate corrective actions for CAU 190. This CAIP describes the investigative approach developed to collect the data needs identified in the DQO process. While a detailed discussion of the DQO methodology and the DQOs specific to each CAS are presented in Appendix A, a summary of the DQO process is provided below.

The DQO problem statement for CAU 190 is: "Existing information on the nature and extent of potential contamination is insufficient to evaluate and recommend corrective action alternatives for the CASs in CAU 190.” To address this question, the resolution of two decisions statements is required:

- Decision I: "Is any contaminant of potential concern (COPC) present in environmental media within the CAS at a concentration exceeding its corresponding final action level (FAL)?" For judgmental sampling, any contaminant associated with a CAS activity that is present at concentrations exceeding its corresponding FAL will be defined as a contaminant of concern (COC). A COC may also be defined as a contaminant that, in combination with other like contaminants, is determined to jointly pose an unacceptable risk based on a multiple constituent analysis (NNSA/NSO, 2006a). If a COC is detected, then Decision II must be resolved. If a COC is not detected, the investigation for that CAS is complete. 
- Decision II: "If a COC is present, is sufficient information available to evaluate potential corrective action alternatives? Sufficient information is defined to include:

- Identifying the lateral and vertical extent of COC contamination in media.

- The information needed to characterize investigation-derived waste (IDW) for disposal.

- The information needed to determine potential remediation waste types.

- The information needed to evaluate the feasibility of remediation alternatives.

The informational inputs and data needs to resolve the problem statement and the decision statements were generated as part of the DQO process for this CAU and are documented in Appendix A. The information necessary to resolve the DQO decisions will be generated for each CAU 190 CAS by collecting and analyzing samples generated during a field investigation. The presence of contamination at each CAS will be determined by collecting and analyzing samples following this criteria:

- $\quad$ For judgmental sampling, samples must be collected in areas most likely to contain a COC.

If it is determined that COCs are present at a CAS, that CAS will be further addressed by determining the extent of contamination before evaluating corrective action alternatives.

\subsection{Scope}

To generate information needed to resolve the decision statements identified in the DQO processes, the scope of the CAI for CAU 190 includes the following activities:

- $\quad$ Move surface debris and/or materials, as needed, to facilitate sampling.

- Conduct radiological surveys.

- $\quad$ Perform field screening.

- Collect and submit environmental samples for laboratory analysis to determine whether COCs are present.

- If COCs are present, collect additional step-out samples to define the lateral and vertical extent of the contamination. 
- Collect samples of source material to determine the potential for a release.

- Collect samples of IDW, as needed, for waste management and minimization purposes.

- Collect quality control (QC) samples.

Contamination of environmental media originating from activities not identified in the conceptual site model (CSM) of any CAS will not be considered as part of this CAU unless the CSM and the DQOs are modified to include the release. As such, contamination originating from these sources will not be considered for sample location selection, and/or will not be considered COCs for Decision II. If such contamination is present, the contamination will be identified as part of another CAS (either new or existing).

\subsection{Corrective Action Investigation Plan Contents}

Section 1.0 presents the purpose and scope of this CAIP, while Section 2.0 provides background information about CAU 190. Objectives of the investigation, including CSMs, are presented in Section 3.0. Field investigation and sampling activities are discussed in Section 4.0, and waste management issues for this project are discussed in Section 5.0. General field and laboratory quality assurance (QA) (including collection of QA samples) are presented in Section 6.0 and in the Industrial Sites Quality Assurance Project Plan (QAPP) (NNSA/NV, 2002a). The project schedule and records availability are discussed in Section 7.0. Section 8.0 provides a list of references.

Appendix A provides a detailed discussion of the DQO methodology and the DQOs specific to each CAS, while Appendix B contains project organization information. 


\subsection{Facility Description}

Corrective Action Unit 190 is comprised of four CASs grouped together based on the geographical location of the sites, and to produce a CAU grouping of sensitive sites that can be investigated together to accommodate potential schedule delays and costs associated with accessing sensitive and classified information. The following four CASs that comprise CAU 190 are located in Areas 11 and 14 of the NTS, as shown in Figure A.2-1. Three of the CAU 190 CASs are within the Tweezer Facility (Figure A.2-2): CAS 11-02-01, Underground Centrifuge; CAS 11-02-02, Drain Lines and Outfall; and CAS 11-59-01, Tweezer Facility Septic System. The fourth, CAS 14-23-01, LTU-6 Test Area (Figure A.9-1), is in the northern part of Area 14.

\subsection{Physical Setting}

This section describes the general physical settings of Areas 11 and 14 of the NTS. General background information pertaining to topography, geology, hydrogeology, and climatology are provided for these specific areas of the NTS region in the Geologic Map of the Nevada Test Site, Southern Nevada (USGS, 1990); CERCLA Preliminary Assessment for DOE's Nevada Operations Office Nuclear Weapons Testing Areas (DRI, 1988); Final Environmental Impact Statement, Nevada Test Site, Nye County, Nevada (ERDA, 1977); and the Final Environmental Impact Statement for the Nevada Test Site and Off-Site Locations in the State of Nevada (DOE/NV, 1996).

Corrective Action Sites 11-02-01, 11-02-02, and 11-59-01 are located within the Yucca Flat Hydrographic Area of the NTS. Corrective Action Site 14-23-01 is located in the Mine Mountain Quadrangle near the southwest margin of Yucca Flat. The low range of hills in west-central Yucca Flat known as Mine Mountain exposes what is called the Mine Mountain thrust. Yucca Flat is a closed basin, which is slowly filling with alluvial deposits eroding from the surrounding mountains (USGS, 1996). Carbonate rocks primarily underlie the alluvium in parts of Yucca Flat and form much of the surrounding mountains in this area (DOE/NV, 1996).

The direction of groundwater flow in Yucca Flat generally is from the northeast to southwest. Within the overlying alluvial and volcanic aquifers, lateral groundwater flow occurs from the margins to the center of the basin and downward into the carbonate aquifer (USGS, 1996). The average annual 
precipitation at Station UCC on the Yucca Flat dry lake is 6.62 inches (in.) (NOAA, 2002). The recharge rate to the Yucca Flat area is relatively low (1.76 millimeters per year) due to the thickness of the unsaturated zone extending to more than 600 feet (ft) below ground surface (bgs) (USGS, 1996).

The nearest groundwater wells to CASs 11-02-01, 11-02-02, and 11-59-01 are U.S. Geological Survey (USGS) Test Well B, which is approximately 6,000 meters (m) northwest of the Tweezer site and USGS Water Well C, which is approximately 5,700 m southwest of the Tweezer site. Test Well B was constructed in June 1961 at a depth of 1,670 ft at 3,931 ft in elevation. The well penetrates the alluvium to a thickness of $548 \mathrm{ft}$, lake deposits from 548 to $770 \mathrm{ft}$, and volcanic tuff from 770 to $1,675 \mathrm{ft}$. The water level at the well is approximately 1,504.5 ft bgs as of 2006 . The densely welded tuffaceous aquifer yields 6 to 8 gallons of water per minute to the well. Test Well B is one of the six test wells drilled at the NTS to determine the local stratigraphy and chemical quality of the groundwater. The water from this well is not used (USGS and DOE, 2006). The USGS Water Well C was installed in September 1961 and reaches a depth of 1,622.38 ft bgs. The well penetrates $81.5 \mathrm{ft}$ of alluvium, $404.5 \mathrm{ft}$ of welded tuff, and $790.5 \mathrm{ft}$ of zeolitized tuff, and limestone (Fenix \& Sisson, Date Unknown).

The closest water well to CAS 14-23-01 is UE-16d. Located in Area 16, UE-16d is 11,100 m northeast of LTU-6. Well UE-16d is currently active. The only well located in Area 14 is USGS Environmental Restoration Program water-level measurement site, UE-14b. The well was constructed in 1983. The approximate groundwater level is $1,700 \mathrm{ft}$ bgs. The water is drawn from multiple aquifers and is used for test purposes only (USGS and DOE, 2006).

Although there is no precipitation monitoring station at CAS 14-23-01, the average annual rainfall is estimated to be 5.0 in. (Winograd and Young, 1965), due to the close proximity to Mine Mountain and Shoshone Mountain.

\subsection{Operational History}

The following subsections provide a description of the use and history of each CAU 190 CAS that may have resulted in potential releases to the environment. The CAS-specific summaries are designed to describe the current definition of each CAS and illustrate significant, known activities. 


\subsubsection{Corrective Action Site 11-02-01, Underground Centrifuge}

The site consists of potential soil contamination resulting from the operation of an underground centrifuge at the Tweezer Facility in Area 11 of the NTS. According to the Desert Research Institute (DRI), the centrifuge is a historically significant object at the NTS. Total petroleum hydrocarbons (TPH) may have contaminated the soil surrounding the centrifuge. This site was originally identified in the Reynolds Electrical \& Engineering Co., Inc. (REECo) document, Nevada Test Site Inventory of Inactive and Abandoned Facilities and Waste Sites as an underground storage tank (UST) on the south side of the Tweezer Facility (REECo, 1991).

The specific activities conducted at the Tweezer Facility are classified. According to interviewees, weapons components were disassembled at the Tweezer Facility. The centrifuge was built to provide an acceleration environment for test units that may contain explosives. The centrifuge was designed and first used in 1972. Hydraulic fluid for the centrifuge was circulated through a pair of high-pressure hoses from a nearby pump house. Because there was no electrical power in the centrifuge, an electric pump in the pump house was powered by a nearby motor generator. It is believed that the pump house was Building 11-1A; however, this has not been confirmed. Remote controls for the centrifuge were located in the disassembly and x-ray room of Building 11-1. After centrifuge operation for a test was completed, the centrifuge was dismantled and critical parts were cleaned and stored. Buildings 11-1 and 11-1A were demolished in 2004.

The centrifuge measures $21.5 \mathrm{ft}$ in diameter and $7 \mathrm{ft} 6$ in. deep. A circular concrete pad surrounds the metal centrifuge, and the top is covered with a metal lid with an access hatch. The inside of the centrifuge contains a spindle and drainpipe connecting to a 5- by 5- by 3-ft gravel-filled drain sump in the floor of the centrifuge. The centrifuge is surrounded by a chain fence supported by several posts imbedded in the concrete. Two hoses connected from the motor and gearbox in the centrifuge to the pump house located approximately $15 \mathrm{ft}$ away. Figure A.2-3 shows a site sketch of CAS 11-02-01.

\subsubsection{Corrective Action Site 11-02-02, Drain Lines and Outfall}

The site consists of a cooling tower, subsurface piping, an outfall and drain line, and the soil surrounding these components, located on the northeast end of Building 11-2 at the Tweezer Facility 
in Area 11 of the NTS. There is a potential release of contamination from the cooling tower, associated subsurface piping, drain line, outfall, and surrounding soil.

Detailed information regarding CAS 11-02-02 is limited because many of the activities conducted at Tweezer are classified. The Tweezer Facility was the location of the Tweezers Tests, which began August 1, 1962. Weapon components were delivered and disassembled at Tweezer. Building 11-2, referred to as the Tweezer Equipment Building, consisted of a battery room, gas compressor room, and mechanical equipment room. The cooling tower was connected to the service water piping at Building 11-2. Two fuel-filled USTs (one of which was originally included in the scope of CAS 11-02-02) were removed from this facility in July 1992. These tanks were previously located on either side of Building 11-2. Figure A.2-4 shows a site sketch of CAS 11-02-02.

\subsubsection{Corrective Action Site 11-59-01, Tweezer Facility Septic System}

The site consists of the septic system associated with former Building 11-1, in the Tweezer Facility, in Area 11 of the NTS. There is a potential of contamination of the septic system and surrounding soil. This site was originally identified as a septic system associated with Building 11-1 during a review of engineering drawings.

The specific activities conducted at the Tweezer Facility are classified. According to interviewees, weapons components were disassembled at the Tweezer Facility. Former Building 11-1 at the Tweezer Facility also was used to disassemble weapons components. It contained a dark room, disassembly room, $\mathrm{x}$-ray room, control room, and test area. This building was demolished, and only a concrete foundation remains. According to engineering drawings, the septic system of CAS 11-59-01 serviced Building 11-1 and was connected to the building in three locations, one on the southwest side and two on the northwest side. Figure A.2-5 shows a sketch of CAS 11-59-01.

\subsubsection{Corrective Action Site 14-23-01, LTU-6 Test Area}

This CAS is located in Area 14 of the NTS near the Mine Mountain Road and Mid Valley Road (Saddle Mountain Road) junction. Corrective Action Site 14-23-01 consists of the soil in the LTU-6 Test Area. The site is the location of the High-Explosive Simulation Test (HEST) area and the LTU-6 
Test Area. There is a potential for TPH, uranium-238 and beryllium soil contamination from activities associated with testing conducted in the area.

Specific information regarding COPCs, sources of contamination, and activities that occurred at LTU-6 is uncertain due to the sensitive nature and limited information available. However, it is known that before being used for the LTU-6 test program, the site was used for three HEST tests.

There was no staining observed in the test area, including in and around the engine generator sheds located near the south end, and the bunker located on the north side, which housed data recording trailers. Other components at the site include a red metal shed and miscellaneous debris. Wire and wood debris are scattered around the bunker area. According to a historical photograph, a sign once posted stated, “DO NOT PICK UP ANY DEBRIS IN AREA.” However, the site is not currently posted. Figure A.9-1 shows CAS 14-23-01.

\subsection{Waste Inventory}

Available documentation, interviews with former site employees, process knowledge, and general historical NTS practices were used to identify wastes that may be present. Historical information and site visits indicate that the sites may contain wastes such as hydrocarbon waste, Resource Conservation and Recovery Act (RCRA) hazardous waste, chromium-contaminated scale and sludge asbestos-containing insulation, various types of metal debris, wires, and other miscellaneous debris.

\subsubsection{Corrective Action Site 11-02-01, Underground Centrifuge}

Waste items identified at CAS 11-02-01 include hydraulic hoses that are potentially full of hydraulic fluid. Lead bricks are also present on the centrifuge floor. Potential waste types include hydrocarbon waste and RCRA hazardous waste.

\subsubsection{Corrective Action Site 11-02-02, Drain Lines and Outfall}

Waste items identified at CAS 11-02-02 include potentially chromium-contaminated scale or sludge inside the cooling tower and possibly asbestos-containing insulation on the water lines connected to the cooling tower. 


\subsubsection{Corrective Action Site 11-59-01, Tweezer Facility Septic System}

No waste items were identified.

\subsubsection{Corrective Action Site 14-23-01, LTU-6 Test Area}

Waste items potentially include metallic depleted uranium, other metal debris, and miscellaneous debris.

\subsection{Release Information}

Known or suspected releases from the CASs, including potential release mechanisms, and migration routes associated with each of the CASs are described in the following subsections. There has been no known migration of contamination at any CAU 190 CASs. Potentially affected media for all CASs include surface and shallow subsurface soil. Exposure routes to site workers include ingestion, inhalation, and/or dermal contact (absorption) from disturbance of contaminated soils or debris. Site workers may also be exposed to radiation by performing activities in proximity to radiologically contaminated materials.

Radiological soil contamination originating from aboveground nuclear testing is specifically excluded from the CAU 190 investigation. This contamination is not associated with a release from CAU 190 and will not be included in the subsequent evaluation of the CASs. If a concern is found at any of the CASs during the CAI, surface soil samples may be obtained outside the respective CAS boundary, and the analytical results will be used for comparison to analytical results of soil samples obtained within the CAS boundary. The following subsections contain CAS-specific descriptions of known or potential releases associated with CAU 190.

\subsubsection{Corrective Action Site 11-02-01, Underground Centrifuge}

There is no reason to suspect that any equipment, materials, or operations associated with this CAS released any contamination. The tests conducted in the centrifuge were not designed to release contaminants. The only possible contamination route would have been leakage of hydraulic oil, but there is no evidence to indicate that this occurred. 


\subsubsection{Corrective Action Site 11-02-02, Drain Lines and Outfall}

Other than normal operation of the discharges to the outfall, there are no known documented releases associated with this CAS. No information exists suggesting that anything other than water wastes were discharged at the outfall.

Unknown contaminants in the building drains may have reached the outfall. If so, such contaminants are expected to have been limited in volume.

\subsubsection{Corrective Action Site 11-59-01, Tweezer Facility Septic System}

Other than normal operation of the septic system, there are no known documented releases associated with this CAS. No information exists suggesting that anything other than sanitary septic wastes were managed and discharged by this septic system.

\subsubsection{Corrective Action Site 14-23-01, LTU-6 Test Area}

There was no observed soil staining to indicate any organic releases from this CAS. There is a possibility of leaching of contaminants from debris scattered within the CAS. If a release occurred from the pieces of debris, contaminants are expected to have been limited in volume.

\subsection{Investigative Background}

The following subsections summarize the investigations conducted at the CAU 190 sites. More detailed discussions of these investigations are found in Appendix A.

\subsubsection{Corrective Action Site 11-02-01, Underground Centrifuge}

During a site visit on July 25, 2006, an inspection of the hoses and the entire pathway from the centrifuge drive to the end of the hoses confirmed that the hoses are intact and there was no evidence of leakage from the hoses. The ends of the hydraulic hoses outside the pit are quick-disconnect fittings.

There are small rocks and sand on the pit floor, probably blown in by wind or washed in by rainfall. There were no stains observed to indicate past leakage of hydraulic fluid or other types of leakage 
inside the pit except for minor staining near the top drive shaft. There are several (approximately 50) lead bricks around the floor perimeter of the centrifuge pit.

\subsubsection{Corrective Action Site 11-02-02, Drain Lines and Outfall}

The location of the discharge point of the oufall pipe was located during a site visit on July 25, 2006. It is approximately $85 \mathrm{ft}$ northwest of the cooling tower. There is a shallow drainage ditch in that area. No remaining deposits appeared to be on the concrete pad under the cooling tower. There are some deposits on the side of the cooling tower where the drain line exits. The insulation on the lines attached to the cooling tower may contain asbestos.

\subsubsection{Corrective Action Site 11-59-01, Tweezer Facility Septic System}

Information on the CAS was collected during a July 25, 2006, site visit as follows:

- $\quad$ No cleanout ports were visible near the Building 11-1 foundation.

- Feeder lines to the overhead power lines inside the Tweezer Facility fence have been cut and the lines are no longer energized.

- Ground disturbance and vegetation growth indicate locations of the drain line to the septic tank, and leachfield, and appear to match the engineering drawings.

- Two stakes that likely mark the location of the septic tank.

- Some general debris (i.e., two chairs) in the area.

\subsubsection{Corrective Action Site 14-23-01, LTU-6 Test Area}

This CAS is defined as the pie-shaped portion of the circular testing area shown in Figure A.9-1. Information was gathered on the Test Area during radiological surveys conducted in September and October 2006. The objective of these radiological land area surveys was to determine whether radiological contamination is present in surficial soil at concentrations statistically greater than surficial soil from undisturbed background locations. The radiological land area survey data provides useful information for preliminary health and safety assessments, support for site investigation sampling strategies, and defines the extent of potential radiological contaminants for focusing characterization efforts. More details regarding the radiological surveys can be found in Section A.2.4. 


\subsection{Objectives}

This section presents an overview of the DQOs for CAU 190 and formulation of the CSM. A summary listing of the contaminants reasonably suspected to be present at each CAS, the COPCs, the preliminary action levels (PALs) for the investigation, and the process used to establish FALs are also presented. Additional details and figures depicting the CSM are in Appendix A.

\subsection{Conceptual Site Model}

The CSM describes the most probable scenario for current conditions at each site and defines the assumptions that are the basis for identifying the future land use, contaminant sources, release mechanisms, migration pathways, exposure points, and exposure routes. The CSM is also used to support appropriate sampling strategies and data collection methods. The CSM has been developed for CAU 190 using information from the physical setting, potential contaminant sources, release information, historical background information, knowledge from similar sites, and physical and chemical properties of the potentially affected media and COPCs. Figure 3-1 depicts a tabular representation of the conceptual pathways to receptors from CAU 190 sources. Figure 3-2 depicts a graphical representation of the CSM. If evidence of contamination not consistent with the presented CSM is identified during investigation activities, the situation will be reviewed, the CSM revised, DQOs re-assessed, and a recommendation made as to how best to proceed. In such cases, decision-makers listed in Section A.3.1 will be notified and given the opportunity to comment on and/or concur with the recommendation.

The following sections discuss future land use and the identification of exposure pathways (i.e., combination of source, release, migration, exposure point, and receptor exposure route) for the CAU.

\subsubsection{Land Use and Exposure Scenarios}

Corrective Action Sites 11-02-01, 11-02-02, and 11-59-01 are located in the land-use zone described as the "Research, Test, and Experiment Zone.” This area is designated for small-scale research and development projects and demonstrations, pilot projects, outdoor tests, and experiments for the development, quality assurance, or reliability of material and equipment under controlled conditions. 


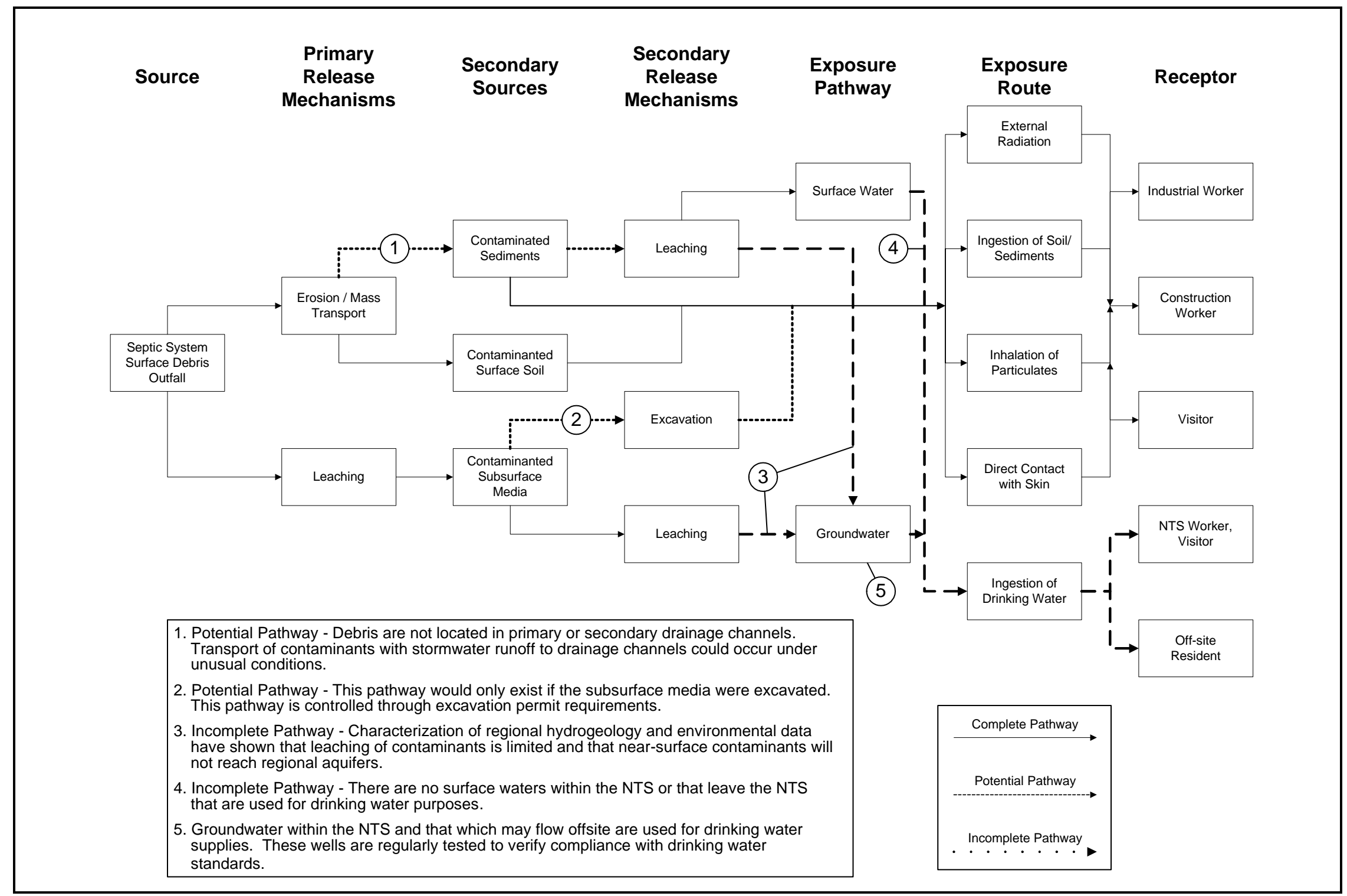

Figure 3-1

Conceptual Site Model Diagram 


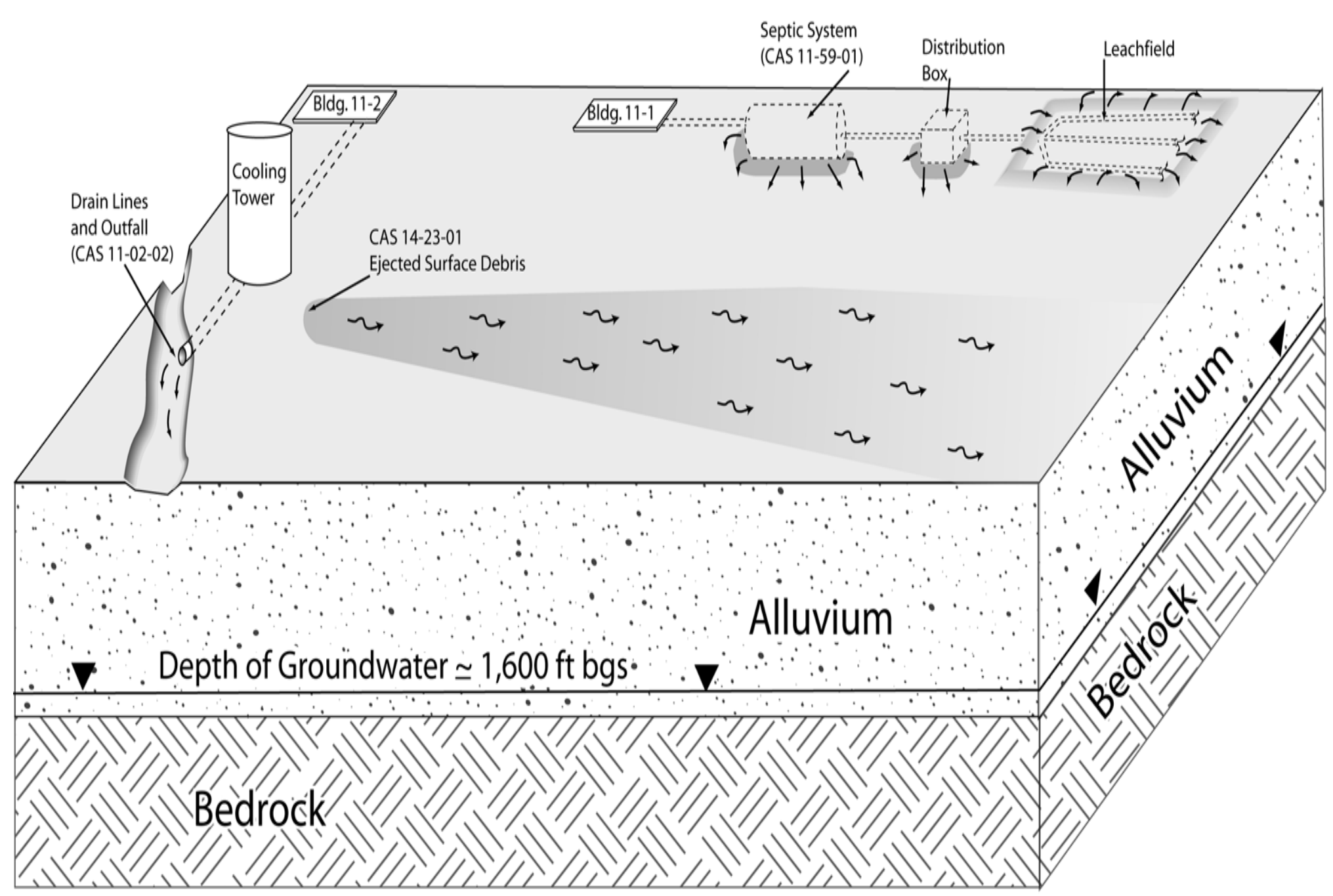

Figure 3-2

Corrective Action Unit 190 Conceptual Site Model 
This zone includes compatible defense and nondefense research, development and testing projects, and activities (DOE/NV, 1998).

Corrective Action Site 14-23-01 is located in the land-use zone described as "Reserved" within the NTS. This area includes land and facilities that provide widespread flexible support for diverse short-term testing and experimentation. The reserved zone is also used for short-duration exercises and training such as nuclear emergency response, Federal Radiological Monitoring and Assessment Center training, and DoD land-navigation exercises and training (DOE/NV, 1998).

All land-use zones where the CAU 190 CASs are located dictate future land use, and restrict current and future land use to nonresidential (i.e., industrial) activities.

The exposure scenario for the CAU 190 CASs has been categorized as Occasional Use Area based on current and projected future land uses. This exposure scenario assumes exposure to industrial workers who are not assigned to the area as a regular worksite but may occasionally use the site for intermittent or short-term activities. A site worker under this scenario is assumed to be on the site for an equivalent of 8 hours per day, 10 days per year, for 5 years.

\subsubsection{Contaminant Sources}

The contamination sources for the CSM are:

- Septic tank, distribution box, associated underground piping, and leachfield.

- Pipe outfall and cooling tower.

- $\quad$ Ejected surface debris.

- Potential future source terms include a septic tank, distribution box, bricks, and hydraulic lines.

\subsubsection{Release Mechanisms}

Release mechanisms for the CSM are spills and leaks onto surface and subsurface soils from the CSM surface and subsurface components. Materials stored in containers (septic tank) may have leaked or spilled. 


\subsubsection{Migration Pathways}

Subsurface migration pathways at the CASs are expected to be predominately vertical, although spills or leaks at the ground surface may also have limited lateral migration before infiltration. The depth of infiltration (shape of the subsurface contaminant plume) will be dependant upon the type, volume, and duration of the discharge; as well as the presence of relatively impermeable layers that could modify vertical or horizontal transport pathways, both on the ground surface (e.g., concrete) and in the subsurface (e.g., caliche layers).

Surface migration pathways for CASs include lateral movement along the desert floor into the soil. Surface migration pathways at the CASs are expected to be minor as all the CASs have shallow surface slopes and the potential release sites are not located in or near drainages.

Migration pathways include the lateral migration of potential contaminants across surface soils/sediments and vertical migration of potential contaminants through subsurface soils. Contaminants released at the Tweezer Facility and LTU-6 Test Area are subject to different transport mechanisms and potentially could end up in washes, which are generally dry, but subject to infrequent, potentially intense, stormwater flows. These stormwater flow events provide an intermittent mechanism for both vertical and horizontal transport of contaminants. Contaminated sediments entrained by these stormwater events would be carried by the streamflow to locations where the flowing water loses energy and the sediments drop out. These locations are readily identifiable by hydrologists as sedimentation areas. Drainage from the Tweezer Facility is ultimately into Yucca Flat (Yucca Lake), which is located west of the site. Yucca Lake is a closed basin with no surface migration pathways off NTS.

Migration is influenced by physical and chemical characteristics of the contaminants and media. Contaminant characteristics include, but are not limited to solubility, density, and adsorption potential. Media characteristics include permeability, porosity, water saturation, sorting, chemical composition, and organic content. In general, contaminants with low solubility, high affinity for media, and high density can be expected to be found relatively close to release points. Contaminants with high solubility, low affinity for media, and low density can be expected to be found further from release points. These factors affect the migration pathways and potential exposure points for the contaminants in the various media under consideration. 
Infiltration and percolation of precipitation serves as a driving force for downward migration of contaminants. Although there is no precipitation monitoring station at CAS 14-23-01, the average annual rainfall is estimated to be 5.0 in. (Winograd and Young, 1965). However, due to high potential evapotranspiration (annual potential evapotranspiration at the Area 3 Radiological Waste Management Site has been estimated at 62.6 in. [Shott et al., 1997]), and limited precipitation for this region is approximately 0.6 in. per year [Winograd and Thordarson, 1975]), percolation of infiltrated precipitation at the NTS does not provide a significant mechanism for vertical migration of contaminants to groundwater (DOE/NV, 1992).

The pathways for contaminant migration will be considered in the development of sampling schemes and sampling contingencies discussed in DQO Step 7, Develop the Plan for Obtaining Data, in Appendix A.

\subsubsection{Exposure Points}

Exposure points for the CSM are expected to be areas of surface contamination where visitors and site workers will come in contact with soil surface. Subsurface exposure points may also exist if construction workers come in contact with contaminated media during excavation activities. Site workers may also be exposed to radiological contamination by performing activities in proximity to radiologically contaminated materials.

\subsubsection{Exposure Routes}

Exposure routes to site workers include exposure to radiation fields, ingestion, inhalation, and/or dermal contact (absorption) from disturbance of, or direct contact with, contaminated media.

\subsubsection{Additional Information}

Information concerning topography, geology, climatic conditions, hydrogeology, floodplains, and infrastructure at the CAU 190 CASs are presented in Section 2.1 as they pertain to the investigation. This information is addressed in the CSM and will be considered, as applicable, during the corrective action alternatives evaluation. Climatic and site conditions (e.g., surface and subsurface soil descriptions) as well as specific structure descriptions will be recorded during the CAI. 


\subsection{Contaminants of Potential Concern}

The COPCs for CAU 190 are defined as the list of constituents represented by the analytical methods identified in Table 3-1 for Decision I environmental samples taken at each of the CASs. The constituents reported for each analytical method are listed in Table 3-2.

Table 3-1

Analytical Program ${ }^{a}$

(Includes Waste Characterization Analyses)

\begin{tabular}{|c|c|c|c|}
\hline Analyses & $\begin{array}{c}\text { CAS } \\
11-02-01^{c}\end{array}$ & $\begin{array}{c}\text { CASs } \\
11-02-02^{\mathrm{d}} \\
\text { and } \\
11-59-01^{\mathrm{e}}\end{array}$ & $\begin{array}{c}\text { CAS } \\
14-23-01\end{array}$ \\
\hline \multicolumn{4}{|c|}{ Organic Contaminants of Potential Concern (COPCs) } \\
\hline Total Petroleum Hydrocarbons-Diesel-Range Organics & $\bar{x}$ & $\bar{x}$ & \\
\hline Total Petroleum Hydrocarbons-Gasoline-Range Organics & & $\bar{x}$ & \\
\hline Polychlorinated Biphenyls & & $\bar{x}$ & \\
\hline Semivolatile Organic Compounds & & $\bar{x}$ & \\
\hline Volatile Organic Compounds & & $\bar{X}$ & \\
\hline \multicolumn{4}{|c|}{ Inorganic COPCs } \\
\hline Explosives & & & $\bar{x}$ \\
\hline RCRA Metals & & $\bar{X}$ & $\bar{x}$ \\
\hline Total Beryllium & & & $\mathrm{x}$ \\
\hline \multicolumn{4}{|c|}{ Radionuclide COPCs } \\
\hline Gamma Spectroscopy $^{\mathrm{b}}$ & & $\bar{x}$ & $\bar{x}$ \\
\hline Isotopic Uranium & & & $\mathrm{X}$ \\
\hline \multicolumn{4}{|c|}{ Waste Characterization Analyses } \\
\hline Tritium & & $\mathrm{X}$ & \\
\hline Asbestos & & $\bar{x}$ & \\
\hline
\end{tabular}

${ }^{\mathrm{a}}$ The COPCs are the constituents reported from the analytical methods listed.

${ }^{\mathrm{b}}$ Results of gamma analysis will be used to determine whether further radioanalytical analysis is warranted.

c If TPH is detected at CAS 11-02-01, then analyze for PCBs, VOCs, and SVOCs.

d Liquid, sludge, or scale from inside the cooling tower will only be analyzed for RCRA metals.

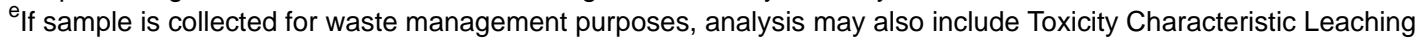

Procedure and pesticides

PCB = Polychlorinated biphenyl

RCRA = Resource Conservation and Recovery Act

SVOC = Semivolatile organic compound

$\mathrm{TPH}=$ Total petroleum hydrocarbons

$\mathrm{VOC}=$ Volatile organic compound

$X=$ Required analytical method 
Table 3-2

Targeted Contaminant for CAU 190

\begin{tabular}{||c|c|c|}
\hline $\begin{array}{c}\text { Corrective } \\
\text { Action Site }\end{array}$ & $\begin{array}{c}\text { Chemical Targeted } \\
\text { Contaminant(s) }\end{array}$ & $\begin{array}{c}\text { Radiological Targeted } \\
\text { Contaminant(s) }\end{array}$ \\
\hline \hline $14-23-01$ & None & Uranium-238 \\
\hline
\end{tabular}

The list of COPCs is intended to encompass all of the potentially present contaminants at each CAS. These COPCs were identified during the planning process through the review of site history, process knowledge, personal interviews, past investigation efforts, and inferred activities associated with the CASs. Contaminants detected at other similar or other NTS sites were also included in the COPC list to reduce the uncertainty about potential contamination at the CASs because complete information regarding activities performed at the CAU 190 sites is not available.

During the review of site history documentation, process knowledge information, personal interviews, past investigation efforts, and inferred activities associated with the CASs, some of the COPCs were identified as targeted contaminants at specific CASs. Targeted contaminants are those COPCs for which evidence in the available site and process information suggests that they may be reasonably suspected to be present at a given CAS. The targeted contaminants are required to meet a more stringent completeness criteria than other COPCs thus providing greater protection against a decision error (see Sections A.1.0 through A.7.0). Targeted contaminants for each CAU 190 CAS are identified in Table 3-3. 
Table 3-3

Constituents Reported by Analytical Methods

\begin{tabular}{|c|c|c|c|c|c|c|c|c|}
\hline \multicolumn{2}{|c|}{ VOCs } & \multicolumn{2}{|c|}{ SVOCs } & TPH & PCBs & Metals & Explosives & $\begin{array}{c}\text { Isotopic } \\
\text { Radionuclides }\end{array}$ \\
\hline $\begin{array}{l}\text { 1,1,1-Trichloroethane } \\
\text { 1,1,1,2-Tetrachloroethane } \\
\text { 1,1,2,2-Tetrachloroethane } \\
\text { 1,1,2-Trichloroethane } \\
\text { 1,1-Dichloroethane } \\
\text { 1,1-Dichloroethene } \\
\text { cis-1,2-Dichloroethene } \\
\text { 1,2-Dichloroethane } \\
\text { 1,2-Dichloropropane } \\
\text { 1,2,4-Trichlorobenzene } \\
\text { 1,2,4-Trimethylbenzene } \\
\text { 1,2-Dibromo-3-chloropropane } \\
\text { 1,3,5-Trimethylbenzene } \\
\text { 1,4-Dioxane } \\
\text { 2-Butanone } \\
\text { 2-Chlorotoluene } \\
\text { 2-Hexanone } \\
\text { 4-Methyl-2-pentanone } \\
\text { Acetone } \\
\text { Acetonitrile } \\
\text { Allyl chloride } \\
\text { Benzene } \\
\text { Bromodichloromethane } \\
\text { Bromoform } \\
\text { Bromomethane } \\
\text { Carbon disulfide } \\
\text { Carbon tetrachloride } \\
\text { Chlorobenzene } \\
\text { Chloroethane } \\
\text { Chloroform } \\
\text { Chloromethane } \\
\text { Chloroprene } \\
\text { Dibromochloromethane } \\
\end{array}$ & $\begin{array}{l}\text { Dichlorodifluoromethane } \\
\text { Ethyl methacrylate } \\
\text { Ethylbenzene } \\
\text { Isobutyl alcohol } \\
\text { Isopropylbenzene } \\
\text { m-Dichlorobenzene }(1,3) \\
\text { Methacrylonitrile } \\
\text { Methyl methacrylate } \\
\text { Methylene chloride } \\
\text { N-Butylbenzene } \\
\text { N-Propylbenzene } \\
\text { o-Dichlorobenzene (1,2) } \\
\text { p-Dichlorobenzene (1,4) } \\
\text { p-isopropyltoluene } \\
\text { sec-Butylbenzene } \\
\text { Styrene } \\
\text { tert-Butylbenzene } \\
\text { Tetrachloroethene } \\
\text { Toluene } \\
\text { Total Xylenes } \\
\text { Trichloroethene } \\
\text { Trichlorofluoromethane } \\
\text { Vinyl acetate } \\
\text { Vinyl Chloride }\end{array}$ & $\begin{array}{l}\text { 2,3,4,6-Tetrachlorophenol } \\
\text { 2,4-Dimethylphenol } \\
\text { 2,4-Dinitrotoluene } \\
\text { 2,4,5-Trichlorophenol } \\
\text { 2,4,6-Trichlorophenol } \\
\text { 2-Chlorophenol } \\
\text { 2-Methylnaphthalene } \\
\text { 2-Methylphenol } \\
\text { 2-Nitrophenol } \\
\text { 3-Methylphenol } \\
\text { 4-Chloroaniline } \\
\text { 4-Methylphenol } \\
\text { 4-Nitrophenol } \\
\text { Acenaphthene } \\
\text { Acenaphthylene } \\
\text { Aniline } \\
\text { Anthracene } \\
\text { Benzo(a)anthracene } \\
\text { Benzo(a)pyrene } \\
\text { Benzo(b)fluoranthene } \\
\text { Benzo(g,h,i)perylene } \\
\text { Benzo(k)fluoranthene } \\
\text { Benzoic Acid } \\
\text { Benzyl Alcohol } \\
\text { Bis(2-ethylhexyl) phthalate } \\
\text { Butyl benzyl phthalate } \\
\text { Carbazole } \\
\text { Chrysene } \\
\text { Dibenzo(a,h)anthracene } \\
\text { Dibenzofuran } \\
\text { Diethyl Phthalate } \\
\text { Dimethyl Phthalate } \\
\text { Di-n-butyl Phthalate } \\
\end{array}$ & $\begin{array}{l}\text { Di-n-octyl Phthalate } \\
\text { Fluoranthene } \\
\text { Fluorene } \\
\text { Hexachlorobenzene } \\
\text { Hexachlorobutadienea } \\
\text { Hexachloroethane } \\
\text { Indeno(1,2,3-cd)pyrene } \\
\text { Naphthalene }^{\mathrm{a}} \\
\text { Nitrobenzene } \\
\text { N-Nitroso-di-n-propylamine } \\
\text { Pentachlorophenol } \\
\text { Phenanthrene } \\
\text { Phenol } \\
\text { Pyrene } \\
\text { Pyridine }\end{array}$ & $\begin{array}{l}\text { TPH } \\
\text { (Diesel-Range Organics } \\
\text { and Gasoline-Range } \\
\text { Organics) }\end{array}$ & \begin{tabular}{|l} 
Aroclor 1016 \\
Aroclor 1221 \\
Aroclor 1232 \\
Aroclor 1242 \\
Aroclor 1248 \\
Aroclor 1254 \\
Aroclor 1260 \\
Aroclor 1268
\end{tabular} & \begin{tabular}{|l} 
Arsenic \\
Barium \\
Beryllium \\
Cadmium \\
Chromium \\
Lead \\
Mercury \\
Selenium \\
Silver \\
Hexavalent \\
Chromium
\end{tabular} & $\begin{array}{l}\text { 1,3,5-Trinitrobenzene } \\
\text { 1,3-Dinitrobenzene } \\
\text { 1,4-Dinitrobenzene } \\
\text { 2,4,6-Trinitrotoluene } \\
\text { 2,4-Dinitrotoluene } \\
\text { 2,6-Dinitrotoluene } \\
\text { 2-Amino-4,6-DNT } \\
\text { 2-Nitrotoluene } \\
\text { 3-Nitrotoluene } \\
\text { 4-Amino-2,6-DNT } \\
\text { 4-Nitrotoluene } \\
\text { HMX } \\
\text { Nitrobenzene } \\
\text { RDX } \\
\text { Tetryl }\end{array}$ & \begin{tabular}{|l|} 
Plutonium-238 \\
Plutonium-239/240 \\
Strontium-90 \\
Uranium-234 \\
Uranium-235 \\
Uranium-238 \\
Tritium \\
Gamma-emitting \\
Radionuclides \\
Actinium-228 \\
Americium-241 \\
Cobalt-60 \\
Cesium-137 \\
Europium-152 \\
Europium-154 \\
Europium-155 \\
Potassium-40 \\
Niobium-94 \\
Lead-212 \\
Lead-214 \\
Thorium-234 \\
Thallium-208 \\
Uranium-235
\end{tabular} \\
\hline
\end{tabular}




\subsection{Preliminary Action Levels}

The PALs presented in this section are for site screening purposes. They are not intended as cleanup action levels or FALs. However, they are useful in screening out contaminants that are not present in sufficient concentrations to warrant further evaluation, therefore streamlining the consideration of remedial alternatives. The risk-based corrective action (RBCA) process used to establish FALs is described in the Industrial Sites Project Establishment of Final Action Levels (NNSA/NSO, 2006a). This process conforms with Nevada Administrative Code (NAC) Section 445A.227 that lists the requirements for sites with soil contamination. For the evaluation of corrective actions, NAC Section 445A.22705 requires the use of American Society for Testing and Materials (ASTM) Method E 1739-95 to "conduct an evaluation of the site, based on the risk it poses to public health and the environment, to determine the necessary remediation standards (i.e., FALs) or to establish that corrective action is not necessary."

This RBCA process, summarized in Figure 3-3, defines the following three tiers (or levels) of evaluation involving increasingly sophisticated analyses:

- Tier 1 - Sample results from source areas (highest concentrations) are compared to action levels based on generic (non-site-specific) conditions (i.e., the PALs established in the CAIP). The FALs may then be established as the Tier 1 action levels or the FALs may be calculated using a Tier 2 evaluation.

- Tier 2 - Conducted by calculating Tier 2 site-specific target levels (SSTLs) using site-specific information as inputs to the same or similar methodology used to calculate Tier 1 action levels. The Tier 2 SSTLs are then compared to individual sample results from reasonable points of exposure (as opposed to the source areas as is done in Tier 1) on a point-by-point basis. Total TPH concentrations will not be used for risk-based decisions under Tier 2 or Tier 3. Rather, the individual chemicals of concern will be compared to the SSTLs.

- Tier 3 - Conducted by calculating Tier 3 SSTLs on the basis of more sophisticated risk analyses using methodologies described in ASTM Method E 1739-95 that consider site-, pathway-, and receptor-specific parameters.

This process includes a provision for conducting an interim remedial action if necessary and appropriate. The decision to conduct an interim action may be made at any time during the investigation at any level (tier) of analysis. Concurrence of the decision-makers listed in Section A.3.1 will be obtained before interim action is implemented. Evaluation of DQO decisions 


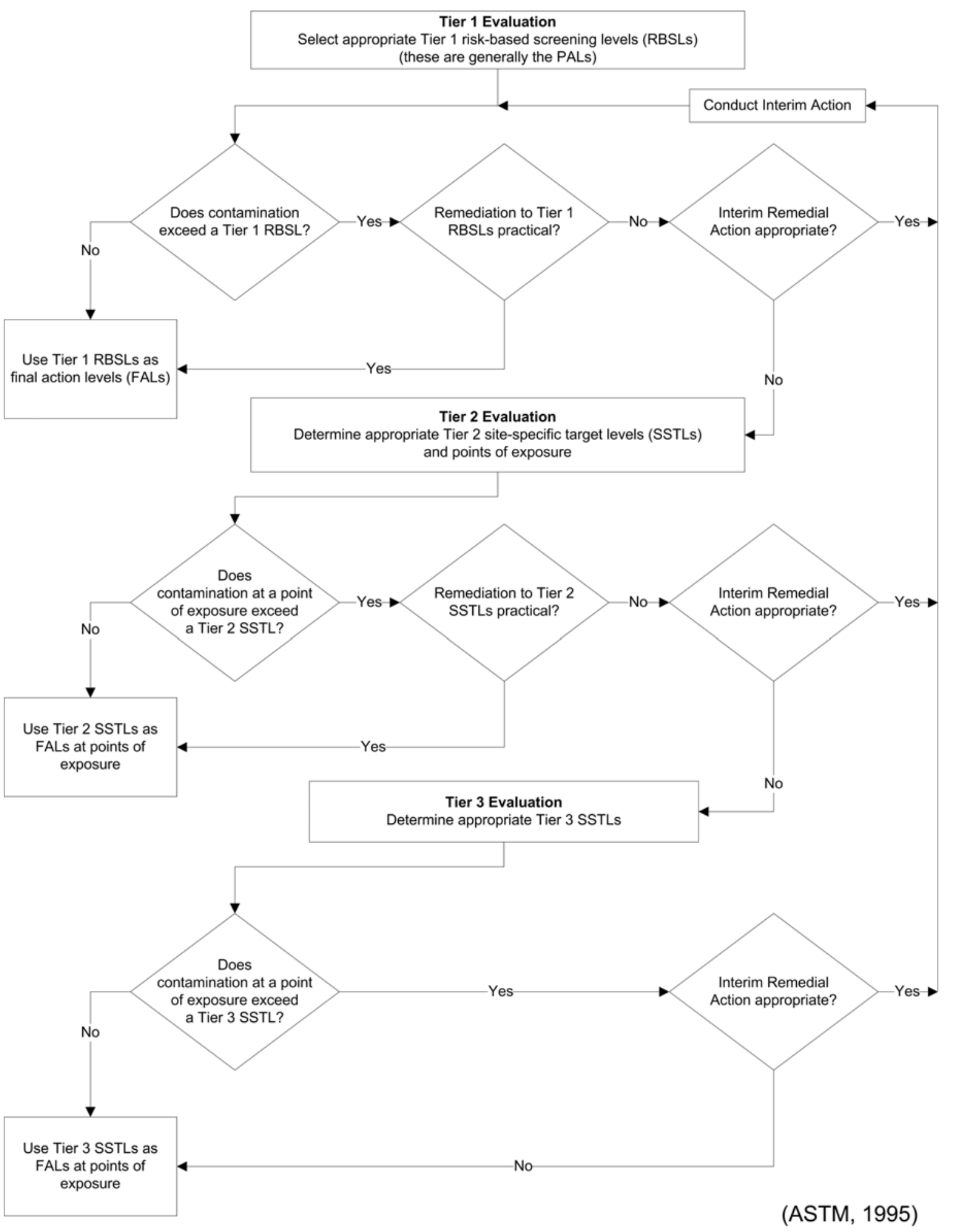

Figure 3-3

Risk-Based Corrective Action Decision Process 
will be based on conditions at the site following completion of interim actions and reported in the investigation report.

The FALs (along with the basis for their selection) will be proposed in the investigation report where they will be compared to laboratory results in the evaluation of potential corrective actions.

\subsubsection{Chemical PALs}

Except as noted herein, the chemical PALs are defined as the U.S. Environmental Protection Agency (EPA) Region 9 Risk-Based Preliminary Remediation Goals (PRGs) for contaminant constituents in industrial soils (EPA, 2004). Background concentrations for RCRA metals will be used instead of PRGs when natural background concentrations exceed the PRG, as is often the case with arsenic on the NTS. Background is considered the mean plus two standard deviations of the mean for sediment samples collected by the Nevada Bureau of Mines and Geology throughout the Nevada Test and Training Range (formerly the Nellis Air Force Range) (NBMG, 1998; Moore, 1999). For detected chemical COPCs without established PRGs, the protocol used by the EPA Region 9 in establishing PRGs (or similar) will be used to establish PALs. If used, this process will be documented in the investigation report.

\subsubsection{Total Petroleum Hydrocarbon PALs}

The PAL for TPH is 100 parts per million (ppm) as listed in NAC 445A.2272 (NAC, 2006b).

\subsubsection{Radionuclide PALs}

The PALs for radiological contaminants (other than tritium) are based on the National Council on Radiation Protection and Measurements (NCRP) Report No. 129 recommended screening limits for construction, commercial, industrial land-use scenarios (NCRP, 1999) using a 25 millirem per year (mrem/yr) dose constraint (Murphy, 2004) and the generic guidelines for residual concentration of radionuclides in DOE Order 5400.5 (DOE, 1993). These PALs are based on the construction, commercial, and industrial land-use scenario provided in the guidance and are appropriate for the NTS based on future land-use scenarios as presented in Section 3.1.1. 
The PAL for tritium is based on the Underground Test Area (UGTA) Project limit of 400,000 picocuries per liter (pCi/L) for discharge of water containing tritium (NNSA/NV, 2002b). The activity of tritium in the soil moisture of soil samples will be reported in units of $\mathrm{pCi} / \mathrm{L}$ for comparison to this PAL.

Solid media such as concrete and/or structures may pose a potential radiological exposure risk to site workers if contaminated. Any materials to be free-released will be done so according to the unrestricted-release criteria defined in the NV/YMP Radiological Control (RadCon) Manual (NNSA/NSO, 2004).

\subsection{Data Quality Objective Process Discussion}

This section contains a summary of the DQO process that is presented in Appendix A. The DQO process is a strategic planning approach based on the scientific method that is designed to ensure that the data collected will provide sufficient and reliable information to identify, evaluate, and technically defend the recommendation of viable corrective actions (e.g., no further action, clean closure, or closure in place).

The DQO strategy for CAU 190 was developed at a meeting on August 24, 2006. The DQOs were developed to identify data needs, clearly define the intended use of the environmental data, and to design a data collection program that will satisfy these purposes. During the DQO discussions for this CAU, the informational inputs or data needs to resolve problem statements and decision statements were documented.

The problem statement for CAU 190 is: "Existing information on the nature and extent of potential contamination is insufficient to evaluate and recommend corrective action alternatives for the CASs in CAU 190.” To address this question, the resolution of two decisions statements is required:

- Decision I: “Is any COC present in environmental media within the CAS?” If a COC is detected, then Decision II must be resolved. Otherwise, the investigation for that CAS is complete. 
- Decision II: "If a COC is present, is sufficient information available to evaluate potential corrective action alternatives?” Sufficient information is defined to include:

- Identifying the volume of media containing any COC bounded by analytical sample results in lateral and vertical directions.

- The information needed to characterize IDW for disposal.

- The information needed to determine potential remediation waste types.

- The information needed to evaluate the feasibility of remediation alternatives (bioassessment if natural attenuation or biodegradation is considered and geotechnical data if construction or evaluation of barriers is considered).

The presence of a COC would require a corrective action. A corrective action may also be necessary if there is a potential for wastes that are present at a site to impose COCs into site environmental media if the wastes were to be released. To evaluate the potential for septic tank contents to result in the introduction of a COC to the surrounding environmental media, the following conservative assumptions were made:

- That the tank containment would fail at some point, and the contents would be released to the surrounding media.

- That the resulting concentration of contaminants in the surrounding media would be equal to the concentration of contaminants in the tank waste.

- That any liquid contaminant in the septic tanks exceeding the RCRA toxicity characteristic concentration can result in introduction of a COC to the surrounding media.

Sludge containing a contaminant exceeding an equivalent FAL concentration would be considered to be potential source material and would require a corrective action. Septic tank liquids with contaminant concentrations exceeding an equivalent toxicity characteristic action level would be considered to be potential source material and would require a corrective action.

Decision I samples will be submitted to analytical laboratories for the analyses listed in Table 3-4. Decision II samples will be submitted for the analysis of all unbounded COCs. In addition, samples will be submitted for analyses as needed to support waste management or health and safety decisions. 
The data quality indicators (DQIs) of precision, accuracy, representativeness, completeness, comparability, and sensitivity needed to satisfy DQO requirements are discussed in Section 6.2. Laboratory data will be assessed in the investigation report to confirm or refute the CSM and determine whether the DQO data needs were met.

To satisfy the DQI of sensitivity (Section 6.2.8), the analytical methods must be sufficient to detect contamination that is present in the samples at concentrations less than or equal to the corresponding FALs. Analytical methods and minimum detectable concentrations (MDCs) for each CAU 190 COPC are provided in Tables 3-4 and 3-5. The MDC is the lowest concentration of a chemical or radionuclide parameter that can be detected in a sample within an acceptable level of error. Due to changes in analytical methodology and analytical laboratory contracts, information that varies from corresponding information in Tables 3-4 and 3-5 will supersede that in the QAPP (NNSA/NV, 2002a).

Table 3-4

Analytical Requirements for Radionuclides for CAU 190

(Page 1 of 2)

\begin{tabular}{|c|c|c|c|c|c|c|}
\hline Parameter/Analyte & Matrix & $\begin{array}{l}\text { Analytical } \\
\text { Method }\end{array}$ & MDC $^{a}$ & $\mathrm{PAL}^{\mathrm{b}, \mathrm{c}}$ & $\begin{array}{l}\text { Laboratory } \\
\text { Precision } \\
\text { (RPD) }\end{array}$ & $\begin{array}{l}\text { Percent } \\
\text { Recovery } \\
(\% \mathrm{R})\end{array}$ \\
\hline \multicolumn{7}{|c|}{ Gamma Spectroscopy } \\
\hline Americium-241 & Soil & HASL-300 ${ }^{\top}$ & $2.0 \mathrm{pCi} / \mathrm{g}^{\mathrm{e}}$ & $12.7 \mathrm{pCi} / \mathrm{g}$ & \multirow{3}{*}{$\begin{array}{c}\text { Relative Percent } \\
\text { Difference (RPD) } \\
35 \% \\
\text { Normalized } \\
\text { Difference } \\
-2<N D<2^{g}\end{array}$} & \multirow{3}{*}{$\begin{array}{c}\text { Laboratory } \\
\text { Control Sample } \\
\text { Recovery } \\
80-120^{\mathrm{h}} \% \mathrm{R}\end{array}$} \\
\hline Cesium-137 & Soil & HASL-300 ${ }^{\dagger}$ & $0.5 \mathrm{pCi} / \mathrm{g}^{\mathrm{e}}$ & $12.2 \mathrm{pCi} / \mathrm{g}$ & & \\
\hline Cobalt-60 & Soil & HASL-300 ${ }^{\dagger}$ & $0.5 \mathrm{pCi} / \mathrm{g}^{\mathrm{e}}$ & $2.68 \mathrm{pCi} / \mathrm{g}$ & & \\
\hline \multicolumn{7}{|c|}{ Other Radionuclides } \\
\hline Tritium & Soil & Lab specific & $400 \mathrm{pCi} / \mathrm{L}^{d}$ & $\begin{array}{c}4.0 \mathrm{E}+05 \\
\mathrm{pCi} / \mathrm{L}^{\mathrm{d}}\end{array}$ & \multirow{3}{*}{$\begin{array}{c}\text { Relative Percent } \\
\text { Difference (RPD) } \\
35 \% \\
\text { Normalized } \\
\text { Difference } \\
-2<\mathrm{ND}<2^{\mathrm{g}}\end{array}$} & \multirow{3}{*}{$\begin{array}{c}\text { Laboratory } \\
\text { Control Sample } \\
\text { Recovery } \\
80-120^{\mathrm{h}} \% \mathrm{R}\end{array}$} \\
\hline Plutonium-238 & Soil & $\begin{array}{c}\text { ASTM } \\
\text { C } 1001-00^{j}\end{array}$ & $0.05 \mathrm{pCi} / \mathrm{g}$ & $13.0 \mathrm{pCi} / \mathrm{g}$ & & \\
\hline Plutonium-239/240 & Soil & $\begin{array}{c}\text { ASTM } \\
\text { C } 1001-00^{j}\end{array}$ & $0.05 \mathrm{pCi} / \mathrm{g}$ & $12.7 \mathrm{pCi} / \mathrm{g}$ & & \\
\hline
\end{tabular}


Table 3-4

\section{Analytical Requirements for Radionuclides for CAU 190}

(Page 2 of 2)

\begin{tabular}{|c|c|c|c|c|c|c|}
\hline Parameter/Analyte & Matrix & $\begin{array}{l}\text { Analytical } \\
\text { Method }\end{array}$ & $\mathrm{MDC}^{\mathrm{a}}$ & $P A L^{b, c}$ & $\begin{array}{l}\text { Laboratory } \\
\text { Precision } \\
\text { (RPD) }\end{array}$ & $\begin{array}{c}\text { Percent } \\
\text { Recovery } \\
\text { (\%R) }\end{array}$ \\
\hline Strontium-90 & Soil & HASL $300^{\prime}$ & $0.5 \mathrm{pCi} / \mathrm{g}$ & $838 \mathrm{pCi} / \mathrm{g}$ & \multirow{4}{*}{$\begin{array}{l}\text { RPD } 35 \% \\
\text { Normalized } \\
\text { Difference } \\
-2<N D<2^{g}\end{array}$} & \multirow{4}{*}{$\begin{array}{c}\text { Chemical Yield } \\
30-105^{\mathrm{i}} \% \mathrm{R} \\
\text { (not applicable } \\
\text { for tritium) }\end{array}$} \\
\hline Uranium-234 & Soil & $\begin{array}{c}\text { ASTM } \\
\text { C } 1000-02^{k}\end{array}$ & $0.05 \mathrm{pCi} / \mathrm{g}$ & $143 \mathrm{pCi} / \mathrm{g}$ & & \\
\hline Uranium-235 & Soil & $\begin{array}{c}\text { ASTM } \\
\text { C } 1000-02^{k}\end{array}$ & $0.05 \mathrm{pCi} / \mathrm{g}$ & $17.6 \mathrm{pCi} / \mathrm{g}$ & & \\
\hline Uranium-238 & Soil & $\begin{array}{c}\text { ASTM } \\
\text { C } 1000-02^{k}\end{array}$ & $0.05 \mathrm{pCi} / \mathrm{g}$ & $105 \mathrm{pCi} / \mathrm{g}$ & & \\
\hline
\end{tabular}

${ }^{\mathrm{a}}$ The MDC is the lowest concentration of a radionuclide, if present in a sample, that can be detected with a 95 percent confidence level.

${ }^{\mathrm{b}}$ The PALs for soil are based on the National Council for Radiation Protection and Measurements (NCRP) Report No. 129 Recommended Screening Limits for Contaminated Soil and Review of Factors Relevant to Site-Specific Studies (NCRP, 1999) scaled to $25 \mathrm{mrem} / \mathrm{yr}$ dose and the guidelines for residual concentration of radionuclides in DOE Order 5400.5 (DOE, 1993). ${ }^{\mathrm{C}} \mathrm{PALs}$ for liquids will be developed as needed.

${ }^{d}$ Units of $\mathrm{pCi} / \mathrm{L}$ will be reported by the analytical laboratory based on the activity of the tritium in the soil moisture. The PAL for tritium in soil is based on the UGTA Project limit of $400,000 \mathrm{pCi} / \mathrm{L}$ for discharge of water containing tritium to an infiltration basin/area (NNSA/NV, 2002b).

${ }^{\mathrm{e}} \mathrm{MDC}$ vary depending on the presence of other gamma-emitting radionuclides in the sample and are relative to the MDC for Cesium-137.

${ }^{\mathrm{f}}$ The Procedures Manual of the Environmental Measurements Laboratory, HASL-300 (DOE, 1997).

${ }^{9} \mathrm{ND}$ is not RPD, it is another measure of precision used to evaluate duplicate analyses. The ND is calculated as the difference between two results divided by the square root of the sum of the squares of their total propagated uncertainties. Evaluation of Radiochemical Data Usability (Paar and Porterfield, 1997).

h EPA Contract Laboratory Program Statement of Work for Inorganic Analysis (EPA, 1988, 1994, 1995).

'General Radiochemistry and Routine Analytical Services Protocol (GRASP) (EG\&G Rocky Flats, 1991). The chemical yield only applies to plutonium, uranium and strontium.

'Standard Test Method for Radiochemical Determination of Plutonium in Soil by Alpha Spectroscopy (ASTM, 2002).

${ }^{\mathrm{k}}$ Standard Test Method for Radiochemical Determination of Uranium Isotopes in Soil by Alpha Spectrometry (ASTM, 2000).

ASTM = American Society for Testing and Materials

HASL = Health and Safety Laboratory

MDC = Minimum detectable concentration

$\mathrm{mrem} / \mathrm{yr}=$ Millirem per year

ND $=$ Normalized difference
$\mathrm{PAL}=$ Preliminary action level

$\mathrm{pCi} / \mathrm{g}=$ Picocuries per gram

$\mathrm{pCi} / \mathrm{L}=$ Picocuries per liter

UGTA = Underground Test Area 
Table 3-5

Analytical Requirements for Chemical COPCs for CAU 190 (Page 1 of 2)

\begin{tabular}{|c|c|c|c|c|c|}
\hline Parameter/Analyte & $\begin{array}{l}\text { Medium } \\
\text { or } \\
\text { Matrix }\end{array}$ & $\begin{array}{l}\text { Analytical } \\
\text { Method }\end{array}$ & $\begin{array}{c}\text { Minimum } \\
\text { Detectable } \\
\text { Concentration } \\
\text { (MDC) }\end{array}$ & $\begin{array}{l}\text { Laboratory } \\
\text { Precision } \\
\text { (RPD) }^{\mathrm{a}}\end{array}$ & $\begin{array}{c}\text { Percent } \\
\text { Recovery } \\
(\% R)^{a}\end{array}$ \\
\hline \multicolumn{6}{|c|}{ Organics } \\
\hline \multirow{2}{*}{ Total Volatile Organic Compounds } & Aqueous & \multirow{2}{*}{$8260 B^{c}$} & \multirow{2}{*}{$\begin{array}{c}\text { Parameter-specific } \\
\text { EQLs }\end{array}$} & \multirow{2}{*}{ Lab-specific $^{\mathrm{e}}$} & \multirow{2}{*}{ Lab-specific $^{\mathrm{e}}$} \\
\hline & Soil & & & & \\
\hline \multirow{2}{*}{$\begin{array}{l}\text { Total Semivolatile Organic } \\
\text { Compounds }\end{array}$} & Aqueous & \multirow{2}{*}{$8270 C^{c}$} & \multirow{2}{*}{$\begin{array}{l}\text { Parameter-specific } \\
\text { EQLs }^{d}\end{array}$} & \multirow{2}{*}{ Lab-specific $^{\mathrm{e}}$} & \multirow{2}{*}{ Lab-specific $^{\mathrm{e}}$} \\
\hline & Soil & & & & \\
\hline \multirow{2}{*}{ Polychlorinated Biphenyls } & Aqueous & \multirow{2}{*}{$8082^{c}$} & \multirow{2}{*}{$\begin{array}{c}\text { Parameter-specific } \\
\text { EQLsf }\end{array}$} & \multirow{2}{*}{ Lab-specific $^{\mathrm{e}}$} & \multirow{2}{*}{ Lab-specific $^{e}$} \\
\hline & Soil & & & & \\
\hline $\begin{array}{l}\text { Total Petroleum Hydrocarbons- } \\
\text { Gasoline-Range Organics }\end{array}$ & Soil & $\begin{array}{c}\text { 8015B } \\
\text { modified }^{\mathrm{c}}\end{array}$ & $0.5 \mathrm{mg} / \mathrm{kg}^{\mathrm{g}}$ & Lab-specific $^{\mathrm{e}}$ & Lab-specific $^{\mathrm{e}}$ \\
\hline $\begin{array}{l}\text { Total Petroleum Hydrocarbons- } \\
\text { Diesel-Range Organics }\end{array}$ & Soil & $\begin{array}{c}\text { 8015B } \\
\text { modified }^{\mathrm{c}}\end{array}$ & $25 \mathrm{mg} / \mathrm{kg}^{\mathrm{g}}$ & Lab-specific $^{\mathrm{e}}$ & Lab-specific $^{\mathrm{e}}$ \\
\hline Explosives & Soil & $8330^{c}$ & $\begin{array}{c}\text { Parameter-specific } \\
\text { EQLs }^{\mathrm{d}}\end{array}$ & Lab-specific $^{\mathrm{e}}$ & Lab-specific $^{\mathrm{e}}$ \\
\hline \multicolumn{6}{|c|}{ Inorganics } \\
\hline \multicolumn{6}{|c|}{ Total RCRA Metals, plus Beryllium } \\
\hline \multirow{2}{*}{ Arsenic } & Aqueous & $6010 B^{c}$ & $0.01 \mathrm{mg} / \mathrm{L}^{\mathrm{g}, \mathrm{h}}$ & $20^{h}$ & \multirow{2}{*}{$\begin{array}{c}\text { Matrix Spike } \\
\text { Recovery } \\
\text { at } 75-125^{\mathrm{h}} \% \mathrm{R}\end{array}$} \\
\hline & Soil & $6010 B^{c}$ & $1 \mathrm{mg} / \mathrm{kg}^{\mathrm{g}, \mathrm{h}}$ & $35^{g}$ & \\
\hline \multirow{2}{*}{ Barium } & Aqueous & $6010 \mathrm{~B}^{\mathrm{C}}$ & $0.20 \mathrm{mg} / \mathrm{L}^{\mathrm{g}, \mathrm{h}}$ & $20^{h}$ & \multirow{6}{*}{$\begin{array}{c}\text { Laboratory } \\
\text { Control Sample } \\
\text { Recovery } \\
\text { at } 80-120^{\mathrm{h}} \% \mathrm{R}\end{array}$} \\
\hline & Soil & $6010 B^{c}$ & $20 \mathrm{mg} / \mathrm{kg}^{\mathrm{g}, \mathrm{h}}$ & $35^{g}$ & \\
\hline \multirow{2}{*}{ Beryllium } & Aqueous & $6010 B^{c}$ & $0.005 \mathrm{mg} / \mathrm{L}^{\mathrm{g}, \mathrm{h}}$ & $20^{h}$ & \\
\hline & Soil & $6010 B^{c}$ & $0.5 \mathrm{mg} / \mathrm{kg}^{\mathrm{g}, \mathrm{h}}$ & $35^{9}$ & \\
\hline \multirow{2}{*}{ Cadmium } & Aqueous & $6010 B^{c}$ & $0.005 \mathrm{mg} / \mathrm{L}^{\mathrm{g}, \mathrm{h}}$ & $20^{h}$ & \\
\hline & Soil & $6010 B^{c}$ & $0.5 \mathrm{mg} / \mathrm{L}^{\mathrm{g}, \mathrm{h}}$ & $35^{g}$ & \\
\hline
\end{tabular}


Table 3-5

Analytical Requirements for Chemical COPCs for CAU 190 (Page 2 of 2)

\begin{tabular}{|c|c|c|c|c|c|}
\hline Parameter/Analyte & $\begin{array}{l}\text { Medium } \\
\text { or } \\
\text { Matrix }\end{array}$ & $\begin{array}{l}\text { Analytical } \\
\text { Method }\end{array}$ & $\begin{array}{c}\text { Minimum } \\
\text { Detectable } \\
\text { Concentration } \\
\text { (MDC) }\end{array}$ & $\begin{array}{l}\text { Laboratory } \\
\text { Precision } \\
\text { (RPD) }^{\mathrm{a}}\end{array}$ & $\begin{array}{c}\text { Percent } \\
\text { Recovery } \\
(\% R)^{\mathrm{a}}\end{array}$ \\
\hline \multirow{2}{*}{ Chromium } & Aqueous & $6010 \mathrm{~B}^{\mathrm{C}}$ & $0.01 \mathrm{mg} / \mathrm{L}^{\mathrm{g}, \mathrm{h}}$ & $20^{11}$ & \multirow{12}{*}{$\begin{array}{c}\text { Laboratory } \\
\text { Control Sample } \\
\text { Recovery } \\
\text { at } \\
80-120^{\mathrm{h}}\end{array}$} \\
\hline & Soil & $6010 B^{c}$ & $1 \mathrm{mg} / \mathrm{kg}^{\mathrm{g}, \mathrm{h}}$ & $35^{g}$ & \\
\hline \multirow{2}{*}{ Hexavalent Chromium } & Aqueous & $7196 A^{c}$ & $0.01 \mathrm{mg} / \mathrm{L}^{\mathrm{g}, \mathrm{h}}$ & $20^{h}$ & \\
\hline & Soil & $7196 A^{c}$ & $1 \mathrm{mg} / \mathrm{kg}^{\mathrm{g}, \mathrm{h}}$ & $35^{g}$ & \\
\hline \multirow{2}{*}{ Lead } & Aqueous & $6010 B^{c}$ & $0.003 \mathrm{mg} / \mathrm{L}^{\mathrm{g}, \mathrm{h}}$ & $20^{h}$ & \\
\hline & Soil & $6010 B^{c}$ & $0.3 \mathrm{mg} / \mathrm{kg}^{\mathrm{g}, \mathrm{h}}$ & $35^{g}$ & \\
\hline \multirow{2}{*}{ Mercury } & Aqueous & $7470 A^{c}$ & $0.0002 \mathrm{mg} / \mathrm{L}^{\mathrm{g}, \mathrm{h}}$ & $20^{h}$ & \\
\hline & Soil & $7471 A^{c}$ & $0.1 \mathrm{mg} / \mathrm{kg}^{\mathrm{g}, \mathrm{h}}$ & $35^{g}$ & \\
\hline \multirow{2}{*}{ Selenium } & Aqueous & $6010 B^{c}$ & $0.005 \mathrm{mg} / \mathrm{L}^{\mathrm{g}, \mathrm{h}}$ & $20^{h}$ & \\
\hline & Soil & $6010 B^{c}$ & $0.5 \mathrm{mg} / \mathrm{kg}^{\mathrm{g}, \mathrm{h}}$ & $35^{g}$ & \\
\hline \multirow{2}{*}{ Silver } & Aqueous & $6010 B^{c}$ & $0.01 \mathrm{mg} / \mathrm{L}^{\mathrm{g}, \mathrm{h}}$ & $20^{h}$ & \\
\hline & Soil & $6010 \mathrm{~B}^{\mathrm{c}}$ & $1 \mathrm{mg} / \mathrm{kg}^{\mathrm{g}, \mathrm{h}}$ & $35^{g}$ & \\
\hline
\end{tabular}

Note: See Table 3-4 for the analytical requirements for radionuclides.

aprecision is estimated from the relative percent difference (RPD) of the laboratory or field duplicates MSD and LCSD are spiked. It is calculated by: $R P D=100 \times\left(\left|A_{1}-A_{2}\right|\right) /\left[\left(A_{1}+A_{2}\right) / 2\right]$, where $A_{1}=$ Concentration of the parameter in the initial sample aliquot,

$A_{2}=$ Concentration of the parameter in the duplicate sample aliquot.

${ }^{b}$ Accuracy is assessed from the \%R of parameters spiked into a blank or sample matrix of interest, or from the recovery of surrogate compounds spiked into each sample. The recovery of each spiked parameter is calculated by: $\% R=100 \times\left(A_{s}-A_{u} / A_{n}\right)$, where $A_{s}=$ Concentration of the parameter in the spiked sample, $A_{u}=$ Concentration of the parameter in the unspiked sample, $A_{n}=$ Concentration increase that should result from spiking the sample.

${ }^{\mathrm{C} T e s t}$ Methods for Evaluating Solid Waste Physical/Chemical Methods, 3rd Edition, Parts 1-4, (SW-846) CD-ROM, Washington, DC (EPA,1996).

${ }^{\mathrm{d}}$ Estimated Quantitation Limit as given in SW-846 (EPA, 1996).

${ }^{\mathrm{e}} \mathrm{RPD}$ and $\% \mathrm{R}$ performance criteria are developed and generated in-house by the laboratory according to approved laboratory procedures.

${ }^{f}$ Contract Laboratory Program Statement of Work for Organic Analysis (EPA, 1999).

${ }^{9}$ Industrial Sites Quality Assurance Project Plan (NNSA/NV, 2002a).

${ }^{\mathrm{h}}$ Contract Laboratory Program Statement of Work for Inorganic Analysis (EPA, 1995).

$\mathrm{EQL}=$ Estimated quantitation limit

LCSD = Laboratory control sample duplicate

$\mathrm{mg} / \mathrm{kg}=$ Milligrams per kilogram

$\mathrm{mg} / \mathrm{L}=$ Milligrams per liter

MSD = Matrix spike duplicate

RCRA = Resource Conservation and Recovery Act

$\mathrm{RPD}=$ Relative percent difference 


\subsection{Field Investigation}

This section contains a description of the activities to be conducted to gather and document information from the CAU 190 field investigation.

\subsection{Technical Approach}

The information necessary to satisfy the DQO data needs will be generated for each CAU 190 CAS by collecting and analyzing samples generated during a field investigation. The presence and nature of contamination at the CASs will be evaluated using a judgmental approach.

If there is a waste present that, if released, has the potential to release significant contamination into site environmental media, that waste will be sampled. If it is determined that a COC is present at any CAS, that CAS will be further addressed by determining the extent of contamination before evaluating corrective action alternatives.

Because this CAIP only addresses contamination originating from the CAU, it may be necessary to distinguish overlapping contamination originating from other sources. For example, widespread surface radiological contamination originating from atmospheric tests will not be addressed in the CAU 190 investigation.

Modifications to the investigative strategy may be required should unexpected field conditions be encountered at any CAS. Significant modifications shall be justified and documented on a Record of Technical Change before implementation. If an unexpected condition indicates that conditions are significantly different than the corresponding CSM, the activity will be rescoped and the identified decision makers will be notified.

\subsection{Field Activities}

Field activities at CAU 190 include site preparation, sample location selection, and sample collection activities. 


\subsubsection{Site Preparation Activities}

Site preparation activities conducted by the NTS Management and Operating Contractor before the investigation may include, but not be limited to relocation or removal of surface debris, equipment, and structures; construction of hazardous waste accumulation areas (HWAAs) and site exclusion zones; providing sanitary facilities; construction of decontamination facilities, and temporarily moving staged equipment.

\subsubsection{Sample Location Selection}

At all the CAU 190 CASs, biasing factors (including field-screening results) will be used to select the most appropriate samples from a particular location for submittal to the analytical laboratory. Biasing factors to be used for selection of sampling locations are listed in Section A.5.2.1. As biasing factors are identified and used for sampling location selection, they will be documented in the appropriate field documents.

The CAS-specific sampling strategy and the estimated locations of biased samples for each CAS are presented in Appendix A. The number, location, and spacing of step-outs may be modified by the Task Manager (TM) or Site Supervisor (SS), as warranted by site conditions, to achieve DQO criteria stipulated in Appendix A. Where sampling locations are modified by the TM or SS, the justification for these modifications will be documented in the field logbook.

\subsubsection{Sample Collection}

The CAU 190 sampling program will consist of the following activities:

- Collect and analyze samples from locations as described in Appendix A.

- Collect required QC samples.

- Collect waste management samples.

- Collect soil samples from background locations, if necessary.

- Perform radiological characterization surveys of construction materials and debris as necessary for disposal purposes. 
- Record Global Positioning System (GPS) coordinates for each environmental sample location.

Decision I surface soil samples (0 to $0.5 \mathrm{ft}$ bgs) will be collected at CASs 11-02-01, 11-02-02, and 14-23-01. Decision I samples will be collected at various depths from CAS 11-59-01. If biasing factors are present in soils below locations where Decision I samples were collected, subsurface Decision I soil samples will also be collected by hand augering and backhoe excavation as appropriate. Decision I subsurface soil samples will be collected at depth intervals selected by the TM or SS based on biasing factors to a depth where the biasing factors are no longer present.

The contents (if present) of the septic tank, distribution box, and cooling tower will be sampled to characterize the waste for potential disposal. Additional information regarding sample locations is available in Section A.9.0.

Decision II sampling will consist of further defining the extent of contamination where COCs have been confirmed. Step-out (Decision II) sampling locations at each CAS will be selected based on the CSM, biasing factors, field-screening results, existing data, and the outer boundary sample locations where COCs were detected. In general, step-out sample locations will be arranged in a triangular pattern around areas containing a COC at distances based on site conditions, COC concentrations, process knowledge, and biasing factors. If COCs extend beyond step-out locations, additional Decision II samples will be collected from locations further from the source. If a spacial boundary is reached, the CSM is shown to be inadequate, or the SS determines that extent sampling needs to be re-evaluated, then work will be temporarily suspended, NDEP notified, and the investigation strategy re-evaluated. A minimum of one analytical result less than the action level from each lateral and vertical direction will be required to define the extent of COC contamination. The lateral and vertical extent of COCs will only be established based on validated laboratory analytical results (i.e., not field screening).

\subsubsection{Sample Management}

The laboratory requirements (i.e., detection limits, precision, and accuracy requirements) to be used when analyzing the COPCs are presented in Tables 3-4 and 3-5. The analytical program for each CAS is presented in Table 3-1. All sampling activities and QC requirements for field and laboratory 
environmental sampling will be conducted in compliance with the Industrial Sites QAPP (NNSA/NV, 2002a) and other applicable, approved procedures.

\subsection{Safety}

A current version of the Environmental Services Architect-Engineer Contractor's programmatic Health and Safety Plan (HASP) and Industrial Sites (IS) HASP will accompany the field documents. A Field Work Permit (FWP), or equivalent, will be prepared and approved before the field effort. As required by the DOE Integrated Safety Management System (ISMS) (DOE/NV, 1997), these documents outline the requirements for protecting the health and safety of the workers, and the public, and the procedures for protecting the environment. The ISMS program requires that site personnel will reduce or eliminate the possibility of injury, illness, or accidents, and to protect the environment during all project activities. The following safety issues will be taken into consideration when evaluating the hazards and associated control procedures for field activities discussed in the IS HASP and FWP:

- Potential hazards to site personnel and the public include, but are not limited to: radionuclides, chemicals (e.g., heavy metals, volatile organic compounds (VOCs), semivolatile organic compounds (SVOCs), and petroleum hydrocarbons), adverse and rapidly changing weather, remote location, and motor vehicle and heavy equipment operations.

- $\quad$ Proper training of site personnel to recognize and mitigate the anticipated hazards.

- Work controls to reduce or eliminate the hazards including engineering controls, substitution of less hazardous materials, and use of appropriate personal protective equipment (PPE).

- Occupational exposure monitoring to prevent overexposures to hazards such as radionuclides, chemicals, and physical agents (e.g., heat, cold, and high wind).

- Radiological surveying for alpha/beta and gamma emitters to minimize and/or control personnel exposures; use of the "as-low-as-reasonably-achievable” principle when addressing radiological hazards.

- Emergency and contingency planning to include medical care and evacuation, decontamination, spill control measures, and appropriate notification of project management. The same principles apply to emergency communications.

- If presumed asbestos-containing material is identified (CFR, 2003b; NAC, 2006a), it will be inspected and/or samples collected by trained personnel. 


\subsection{Site Restoration}

Following completion of CAI and waste management activities, the following actions will be implemented before closure of the site Real Estate/Operations Permit:

- Removal of all equipment, wastes, debris, and materials associated with the CAI.

- Removal of all signage and fencing (unless part of a corrective action).

- Grading of site to pre-investigation condition (unless changed condition is necessary under a corrective action).

- Site will be inspected and certified that restoration activities have been completed. 


\subsection{Waste Management}

Management of IDW will be based on regulatory requirements, field observations, process knowledge, and laboratory results from CAU 190 investigation samples.

Disposable sampling equipment, PPE, and rinsate are considered potentially contaminated waste only by virtue of contact with potentially contaminated media (e.g., soil) or potentially contaminated debris (e.g., construction materials). Therefore, sampling and analysis of IDW, separate from analyses of site investigation samples, may not be necessary for all IDW. However, if associated investigation samples are found to contain contaminants above regulatory levels, conservative estimates of total waste contaminant concentrations may be made based on the mass of the waste, amount of contaminated media contained in the waste, and maximum concentration of contamination found in the media. Direct samples of IDW may also be taken to support waste characterization.

Sanitary, hazardous, radioactive, and/or mixed waste, if generated, will be managed and disposed of in accordance with applicable DOE orders, U.S. Department of Transportation (DOT) regulations, state and federal waste regulations, and agreements and permits between DOE and NDEP.

\subsection{Waste Minimization}

Investigation activities are planned to minimize IDW generation. This will be accomplished by incorporating the use of process knowledge, visual examination, and/or radiological survey and swipe results. When possible, disturbed media (such as soil removed during trenching) or debris will be returned to its original location. Contained media (e.g., soil managed as waste) as well as other IDW will be segregated to the greatest extent possible to minimize generation of hazardous, radioactive, or mixed waste. Hazardous material used at the sites will be controlled to limit unnecessary generation of hazardous or mixed waste. Administrative controls including decontamination procedures and waste characterization strategies will minimize waste generated during investigations. 


\subsection{Potential Waste Streams}

Waste generated during the investigation activities will include the following potential waste streams:

- Personal protective equipment and disposable sampling equipment (e.g., plastic, paper, sample containers, aluminum foil, spoons, bowls)

- Decontamination rinsate

- Environmental media (e.g., soil)

- Surface debris in investigation area (e.g., lead bricks)

- Field-screening waste (e.g., spent solvent, disposable sampling equipment, and/or PPE contaminated by field-screening activities)

\subsection{Investigation-Derived Waste Management}

The on-site management and ultimate disposition of IDW will be determined based on a determination of the waste type (e.g., sanitary, low-level, hazardous, hydrocarbon, mixed), or the combination of waste types. A determination of the waste type will be guided by several factors, including, but not limited to analytical results of samples, directly or indirectly associated with the waste; historical site knowledge, waste generation process knowledge, field observations, field-monitoring/screening results, and/or radiological survey/swipe results.

Table 4-2 of the NV/YMP RadCon Manual (NNSA/NSO, 2004) shall be used to determine whether such materials may be released. On-site IDW management requirements by waste type are detailed in the following sections. Applicable waste management regulations and requirements are listed in Table 5-1.

\subsubsection{Sanitary Waste}

Sanitary IDW generated at each CAS will be collected, managed, and disposed of in accordance with the sanitary waste management regulations and permits for operation of the NTS 10c Industrial Waste Landfill.

Office trash and lunch waste will be placed in the dumpster to be transported to the sanitary landfill for disposal. Sanitary IDW generated will only be collected in plastic bags, sealed, labeled with the 
Table 5-1

Waste Management Regulations and Requirements

\begin{tabular}{|c|c|c|}
\hline Waste Type & Federal Regulation & Additional Requirements \\
\hline Solid (nonhazardous) & $\mathrm{N} / \mathrm{A}$ & $\begin{array}{c}\text { NRS }^{\mathrm{a}} 444.440-444.620 \\
\text { NAC }^{\mathrm{b}} 444.570-444.7499 \\
\text { NTS Landfill Permit SW13.097.04 } \\
\text { NTS Landfill Permit SW13.097.03 }\end{array}$ \\
\hline Liquid/Rinsate (nonhazardous) & $\mathrm{N} / \mathrm{A}$ & $\begin{array}{l}\text { Water Pollution Control General Permit } \\
\text { GNEV93001, Rev. 3iii }\end{array}$ \\
\hline Hazardous & $\begin{array}{c}\text { RCRA }^{f}, \\
40 \text { CFR 260-282 }\end{array}$ & $\begin{array}{c}\text { NRS }^{a} 459.400-459.600 \\
\text { NAC }^{b} 444.850-444.8746 \\
\text { POC }^{g}\end{array}$ \\
\hline Low-Level Radioactive & $\mathrm{N} / \mathrm{A}$ & DOE Orders and NTSWAC \\
\hline Mixed & $\begin{array}{c}\text { RCRA }^{f}, \\
40 \text { CFR 260-282 }\end{array}$ & $\begin{array}{l}\text { NTSWAC } \\
\text { POC }^{\mathrm{h}}\end{array}$ \\
\hline Hydrocarbon & $\mathrm{N} / \mathrm{A}$ & $\begin{array}{c}\text { NTS Landfill Permit SW13.097.02 } \\
\text { NAC }^{\text {b }} 445 a .2272\end{array}$ \\
\hline Polychlorinated Biphenyls & $\begin{array}{c}\text { TSCA }^{\mathrm{j}} \\
40 \text { CFR } 761\end{array}$ & $\begin{array}{l}N^{N R S^{a}} 459.400-459.600 \\
N A C^{b} 444.940-444.9555\end{array}$ \\
\hline Asbestos & $\begin{array}{c}\text { TSCA } \\
40 \text { CFR } 763\end{array}$ & $\begin{array}{l}\text { NRS }^{a} \text { 618.750-618.840 } \\
\text { NAC }^{\text {b }} 444.965-444.976\end{array}$ \\
\hline
\end{tabular}

${ }^{\mathrm{a}}$ Nevada Revised Statutes (NRS, 2005a, b, c)

${ }^{\mathrm{b}}$ Nevada Administrative Code (NAC, 2006a, b)

cArea 23 Class II Solid Waste Disposal Site (NDEP, 1997a)

${ }^{\mathrm{d}}$ Area 9 Class III Solid Waste Disposal Site (NDEP, 1997c)

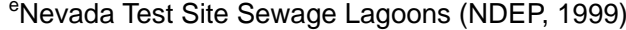

${ }^{\mathrm{f}}$ Resource Conservation and Recovery Act (CFR, 2006)

${ }^{9}$ Nevada Test Site Performance Objective for the Certification of Nonradioactive Hazardous Waste (BN, 1995)

${ }^{\mathrm{h}}$ Nevada Test Site Waste Acceptance Criteria, Rev. 6 (NNSA/NSO, 2006b)

'Area 6 Class III Solid Waste Disposal Site for hydrocarbon waste (NDEP, 1997b)

${ }^{\mathrm{j}}$ Toxic Substance Control Act (CFR, 2003a, b)

CFR $=$ Code of Federal Regulations

$\mathrm{DOE}=$ U.S. Department of Energy

N/A = Not applicable

NAC $=$ Nevada Administrative Code

NRS $=$ Nevada Revised Statutes

NTS = Nevada Test Site

NTSWAC $=$ Nevada Test Site Waste Acceptance Criteria

$\mathrm{POC}=$ Performance Objective for the Certification of Nonradioactive Hazardous Waste

RCRA = Resource Conservation and Recovery Act

TSCA = Toxic Substance Control Act

CAS number from each site from which it was generated, and dated. The waste will then be placed in a roll-off box located in Mercury, or other approved roll-off box location. The number of bags of sanitary IDW will be counted and placed in the roll-off box, noted in a log, and documented in the Field Activity Daily Log (FADL). These logs will provide necessary tracking information for ultimate disposal in the 10c Industrial Waste Landfill. 


\subsubsection{Low-Level Radioactive Waste}

Radiological swipe surveys and/or direct-scan surveys may be conducted on reusable sampling equipment and the PPE and disposable sampling equipment waste streams exiting a radiologically controlled area (RCA). This allows for the immediate segregation of radioactive waste from waste that may be unrestricted regarding radiological release. Contamination limits, as defined in Table 4-2 of the NV/YMP RadCon Manual (NNSA/NSO, 2004), will be used to determine whether such waste may be declared unrestricted regarding radiological release versus being declared radioactive waste. Direct sampling of the waste may be conducted to aid in determining whether a particular waste unit (e.g., drum of soil) contains low-level radioactive waste, as necessary. Waste that is determined to be below the values of Table 4-2, by either direct radiological survey/swipe results or through process knowledge, will not be managed as potential radioactive waste but in accordance with the appropriate section of the NV/YMP RadCon Manual. Wastes in excess of Table 4-2 values will be managed as potential radioactive waste and be managed in accordance with this section and any other applicable sections of this document.

Low-level radioactive waste, if generated, will be managed in accordance with the contractor-specific waste certification program plan, DOE orders, and the requirements of the current version of the Nevada Test Site Waste Acceptance Criteria (NTSWAC) (NNSA/NSO, 2006b). Potential radioactive waste drums containing soil, PPE, disposable sampling equipment, and/or rinsate may be staged at a designated radioactive material area (RMA) or RCA when full or at the end of an investigation phase. The waste drums will remain at the RMA pending certification and disposal under NTSWAC requirements (NNSA/NSO, 2006b).

\subsubsection{Hazardous Waste}

The CAU will have waste accumulation areas established according to the needs of the project. Satellite accumulation areas and HWAAs will be managed consistent with the requirements of federal and state regulations (CFR, 2006; NAC, 2006b). The HWAAs will be properly controlled for access, equipped with spill kits, and appropriate spill containment. Suspected hazardous wastes will be placed in DOT-compliant containers. All containerized hazardous waste will be handled, inspected, and managed in accordance with Title 40 CFR 265 Subpart I (CFR, 2006). These provisions include managing the waste in containers compatible with the waste type, and segregating incompatible waste 
types so that in the event of a spill, leak, or release, incompatible wastes shall not contact one another. The HWAAs will be covered under a site-specific emergency response and contingency action plan until such time that the waste is determined to be nonhazardous or all containers of hazardous waste have been removed from the storage area. Hazardous waste will be characterized in accordance with the requirement of Title 40 CFR 261. Resource Conservation and Recovery Act-“listed” waste has not been identified at CAU 190. Any waste determined to be hazardous will be managed and transported in accordance with RCRA and DOT requirements to a permitted treatment, storage, and disposal facility (CFR, 2006).

\subsubsection{Hydrocarbon Waste}

Hydrocarbon soil waste containing more than 100 milligrams per kilogram of TPH will be managed on site in a drum or other appropriate container until fully characterized. Hydrocarbon waste may be disposed of at a designated hydrocarbon landfill (NDEP, 1997b), an appropriate hydrocarbon waste management facility (e.g., recycling facility), or other method in accordance with NDEP regulations.

\subsubsection{Mixed Low-Level Waste}

Mixed waste, if generated, shall be managed and dispositioned according to the requirements of RCRA (CFR, 2006) or subject to agreements between NNSA/NSO and the State of Nevada, as well as DOE requirements for radioactive waste. The waste will be marked with the words "Hazardous Waste Pending Analysis and Radioactive Waste Pending Analysis.” Waste characterized as mixed will not be stored for a period of time that exceeds the requirements of RCRA unless subject to agreements between NNSA/NSO and the State of Nevada. The mixed waste shall be transported via an approved hazardous waste/radioactive waste transporter, to the NTS transuranic waste storage pad, for storage pending treatment or disposal. Mixed waste with hazardous waste constituent concentrations below Land Disposal Restrictions may be disposed of at the NTS Area 5 Radioactive Waste Management Site if the waste meets the requirements of the NTSWAC (NNSA/NSO, 2006b), the NTS NDEP permit for a Hazardous Waste Management Facility (NEV HW0009 [NDEP, 2000]), and the RCRA Part B Permit Application for Waste Management Activities at the Nevada Test Site (DOE/NV, 1999). Mixed waste constituent concentrations exceeding Land Disposal Restrictions will require development of a treatment and disposal plan under the requirements of the Mutual Consent Agreement between DOE and NDEP (NDEP, 1995). 


\subsubsection{Polychlorinated Biphenyls}

Polychlorinated biphenyls (PCBs) management is governed by the Toxic Substances Control Act (TSCA) (USC, 1976) and its implementing regulations at 40 CFR 761 (CFR, 2003a).

Polychlorinated biphenyl contamination may be found as a sole contaminant or in combination with any of the types of waste discussed in this document. For example, PCBs may be a co-contaminant in soil that contains a RCRA “characteristic” waste (PCB/hazardous waste), or in soil that contains radioactive wastes (PCB/radioactive waste), or even in mixed waste (PCB/radioactive/hazardous waste). The IDW will be evaluated initially using analytical results for media samples from the investigation. If any type of PCB waste is generated, it will be managed according to 40 CFR 761 (CFR, 2003a) as well as State of Nevada requirements, (NAC, 2006a) guidance, and agreements with NNSA/NSO.

\subsection{Management of Specific Waste Streams}

\subsubsection{Personal Protective Equipment}

Personal protective equipment and disposable sampling equipment will be inspected visually for stains, discoloration, and gross contamination as the waste is generated, and also evaluated for radiological contamination. Staining and/discoloration will be assumed to be the result of contact with potentially contaminated media such as soil, sludge, or liquid. Gross contamination is the visible contamination of an item (e.g., clumps of soil/sludge on a sampling spoon or free liquid smeared on a glove). While gross contamination often can be removed through decontamination methods, removal of gross contamination from small items, such as gloves or booties, is not typically conducted. Any IDW that meets this description will be segregated and managed as potentially "characteristic" hazardous waste. This segregated population of waste will be either assigned the characterization of the soil/sludge that was sampled, sampled directly, or undergo further evaluation using the soil/sludge sample results to determine how much soil/sludge would need to be present in the waste to exceed regulatory levels. Waste that is determined to be hazardous will be entered into an approved waste management system, where it will be managed and dispositioned according to RCRA requirements or subject to agreements between NNSA/NSO and the State of Nevada. The PPE and equipment not visibly stained, discolored, or grossly contaminated, and that is within the radiological free-release criteria, will be managed as nonhazardous sanitary waste. 


\subsubsection{Management of Decontamination Rinsate}

Rinsate at CAU 190 will not be considered hazardous waste unless there is evidence that the rinsate may display a RCRA characteristic. Evidence may include such things as the presence of a visible sheen, $\mathrm{pH}$, or association with equipment/materials used to respond to a release/spill of a hazardous waste/substance. Decontamination rinsate that is potentially hazardous (using associated sample results and/or process knowledge) will be managed as characteristic hazardous waste (CFR, 2006). The regulatory status of the potentially hazardous rinsate will be determined through the application of associated sample results or through direct sampling. If the associated samples do not indicate the presence of hazardous constituents, then the rinsate will be considered to be nonhazardous.

The disposal of nonhazardous rinsate will be consistent with guidance established in current NNSA/NSO Fluid Management Plans for the NTS as follows:

- Rinsate that is determined to be nonhazardous and contaminated to less than 5x Safe Drinking Water Standards (SDWS) is not restricted as to disposal. Nonhazardous rinsate which is contaminated at 5x to 10x SDWS will be disposed of in an established infiltration basin or solidified and disposed of as sanitary waste or low-level waste in accordance with the respective sections of this document.

- Nonhazardous rinsate which is contaminated at greater than 10x SDWS will be disposed of in a lined basin or solidified and disposed of as sanitary waste or low-level waste in accordance with the respective sections of this document.

\subsubsection{Management of Soil}

This waste stream consists of soil removed for disposal during soil sampling, excavation, and/or drilling. This waste stream will be characterized based on laboratory analytical results from representative locations. If the soil is determined to potentially contain COCs, the material will either be managed on site or containerized for transportation to an appropriate disposal site.

On-site management of the waste soil will be allowed only if it is managed within an area of concern and it is appropriate to defer the management of the waste until the final remediation of the site. If this option is chosen, the waste soil shall be protected from run-on and run-off using appropriate protective measures based on the type of contaminant(s) (e.g., covered with plastic and bermed). 
Management of soil waste for disposal consists of placing the waste in containers, labeling the containers, temporarily storing the containers until shipped, and shipping the waste to a disposal site. The containers, labels, management of stored waste, transport to the disposal site, and disposal shall be appropriate for the type of waste (e.g., hazardous, hydrocarbon, mixed).

Note that soils placed back into a borehole or excavation in the same approximate location from which it originated is not considered to be a waste.

\subsubsection{Management of Debris}

This waste stream can vary depending on site conditions. Debris that requires removal for the investigation activities (soil sampling, excavation, and/or drilling) must be characterized for proper management and disposition. Historical site knowledge, waste generation process knowledge, field observations, field-monitoring/screening results, radiological survey/swipe results and/or the analytical results of samples either directly or indirectly associated with the waste may be used to characterized the debris. Debris will be visually inspected for stains, discoloration, and gross contamination. Debris may be deemed reusable, recyclable, sanitary waste, hazardous waste, PCB waste, or low-level waste. Waste that is not sanitary will be entered into an approved waste management system where it will be managed and dispositioned according to federal, state requirements, and agreements between NNSA/NSO and the State of Nevada. The debris will be managed on site by berming and covering next to the excavation, by placement in a container(s), or left on the footprint of the CAS, and its disposition deferred until implementation of corrective action at the site.

\subsubsection{Field-Screening Waste}

The use of field test kits and/or instruments may result in the generation of small quantities of hazardous wastes. If hazardous waste is produced by field screening, it will be segregated from other IDW and managed in accordance with the hazardous waste regulations (CFR, 2006). For sites where field-screening samples contain radioactivity above background levels, field-screening methods that have the potential to generate hazardous waste will not be used, thus avoiding the potential to generate mixed waste. In the event a mixed waste is generated, it will be managed in accordance with requirements identified in Section 5.3.5. 


\subsection{Quality Assurance/Quality Control}

The overall objective of the characterization activities described in this CAIP is to collect accurate and defensible data to support the selection and implementation of a closure alternative for each CAU 190 CAS. Sections 6.1 and 6.2 discuss the collection of required QC samples in the field and QA requirements for laboratory/analytical data to achieve closure. Unless otherwise stated in this CAIP, or required by the results of the DQO process (see Appendix A), this investigation will adhere to the Industrial Sites QAPP (NNSA/NV, 2002a).

\subsection{Quality Control Sampling Activities}

Field QC samples will be collected in accordance with established procedures. Field QC samples are collected and analyzed to aid in determining the validity of environmental sample results. The number of required QC samples depends on the types and number of environmental samples collected. The minimum frequency of collecting and analyzing QC samples for this investigation, as determined in the DQO process, include:

- Trip blanks (1 per sample cooler containing VOC environmental samples)

- Equipment rinsate blanks (1 at CAS 11-59-01)

- Source blanks (1 per lot of source material that contacts sampled media)

- $\quad$ Field duplicates (1 per CAS per matrix or 1 per 20 environmental samples)

- Field blanks (1 per CAS)

- $\quad$ Laboratory QC samples (1 per CAS)

Additional QC samples may be submitted based on site conditions at the discretion of the TM or SS. Field QC samples shall be analyzed using the same analytical procedures implemented for associated environmental samples. Additional details regarding field QC samples are available in the Industrial Sites QAPP (NNSA/NV, 2002a).

\subsection{Laboratory/Analytical Quality Assurance}

Criteria for the investigation, as stated in the DQOs (Appendix A) and except where noted, require laboratory analytical quality data be used for making critical decisions. Rigorous QA/QC will be implemented for all laboratory samples including documentation, data verification and validation of analytical results, and an assessment of DQIs as they relate to laboratory analysis. 


\subsubsection{Data Validation}

Data verification and validation will be performed in accordance with the Industrial Sites QAPP (NNSA/NV, 2002a), except where otherwise stipulated in this CAIP. All chemical and radiological laboratory data from samples that are collected and analyzed will be evaluated for data quality according to company-specific procedures. The data will be reviewed to ensure that all suspected samples were appropriately collected, analyzed, and the results passed data validation criteria. Validated data, including estimated data (i.e., J-qualified), will be assessed to determine whether they meet the DQO requirements of the investigation and the performance criteria for the DQIs. The results of this assessment will be documented in the Corrective Action Decision Document (CADD). If the DQOs were not met, corrective actions will be evaluated, selected, and implemented (e.g., refine CSM or resample to fill data gaps).

\subsubsection{Data Quality Indicators}

The DQIs are qualitative and quantitative descriptors used to interpret the degree of acceptability or utility of data. Data quality indicators are used to evaluate the entire measurement system and laboratory measurement processes (i.e., analytical method performance) as well as to evaluate individual analytical results (i.e., parameter performance). The quality and usability of data used to make DQO decisions will be assessed based on the following DQIs:

- Precision

- Accuracy/bias

- Representativeness

- Comparability

- Completeness

- Sensitivity

Table 6-1 provides the established analytical method/measurement system performance criteria for each of the DQIs and the potential impacts to the decision if the criteria are not met. The following subsections discuss each of the DQIs that will be used to assess the quality of laboratory data. Due to changes in analytical methodology and analytical laboratory contracts, information that varies from corresponding information in Tables 3-4 and 3-5 will supersede that in the QAPP (NNSA/NV, 2002a). 
Table 6-1

\section{Laboratory and Analytical Performance Criteria for CAU 190 Data Quality Indicators}

\begin{tabular}{|c|c|c|}
\hline $\begin{array}{l}\text { Data Quality } \\
\text { Indicator }\end{array}$ & Performance Metric & $\begin{array}{l}\text { Potential Impact on Decision } \\
\text { If Performance Metric Not Met }\end{array}$ \\
\hline Precision & $\begin{array}{l}\text { At least } 80 \% \text { of the sample results for each } \\
\text { measured contaminant are not qualified for } \\
\text { precision based on the criteria for each analytical } \\
\text { method-specific and laboratory-specific criteria } \\
\text { presented in Section } 6.2 .3 \text {, or for the field } \\
\text { duplicate criteria of } 80 \% \text { RPD or } 2 \% \text { ND. }\end{array}$ & $\begin{array}{l}\text { If the performance metric is not met, the } \\
\text { affected analytical results from each } \\
\text { affected CAS will be assessed to determine } \\
\text { whether there is sufficient confidence in } \\
\text { analytical results to use the data in DQO } \\
\text { decision-making. }\end{array}$ \\
\hline Accuracy & $\begin{array}{l}\text { At least } 80 \% \text { of the sample results for each } \\
\text { measured contaminant are not qualified for } \\
\text { accuracy based on the method-specific and } \\
\text { laboratory-specific criteria presented in } \\
\text { Section } 6.2 .4 \text {. }\end{array}$ & $\begin{array}{l}\text { If the performance metric is not met, the } \\
\text { affected analytical results from each } \\
\text { affected CAS will be assessed to determine } \\
\text { whether there is sufficient confidence in } \\
\text { analytical results to use the data in DQO } \\
\text { decision-making. }\end{array}$ \\
\hline Sensitivity & $\begin{array}{l}\text { Minimum detectable concentrations are less than } \\
\text { or equal to respective FALs. }\end{array}$ & $\begin{array}{l}\text { Cannot determine whether COCs are } \\
\text { present or migrating at levels of concern. }\end{array}$ \\
\hline Comparability & $\begin{array}{l}\text { Sampling, handling, preparation, analysis, } \\
\text { reporting, and data validation are performed } \\
\text { using standard methods and procedures. }\end{array}$ & $\begin{array}{l}\text { Inability to combine data with data obtained } \\
\text { from other sources and/or inability to } \\
\text { compare data to regulatory action levels. }\end{array}$ \\
\hline Representativeness & $\begin{array}{l}\text { Samples contain contaminants at concentrations } \\
\text { present in the environmental media from which } \\
\text { they were collected. }\end{array}$ & $\begin{array}{l}\text { Analytical results will not represent true site } \\
\text { conditions. Inability to make appropriate } \\
\text { DQO decisions. }\end{array}$ \\
\hline Completeness & $\begin{array}{l}80 \% \text { of the CAS-specific COPCs have valid } \\
\text { results. } \\
100 \% \text { of CAS-specific targeted contaminants } \\
\text { have valid results. }\end{array}$ & $\begin{array}{l}\text { Cannot support/defend decision on whether } \\
\text { COCs are present. }\end{array}$ \\
\hline Extent Completeness & $\begin{array}{l}100 \% \text { of COCs used to define extent have valid } \\
\text { results. }\end{array}$ & $\begin{array}{l}\text { Extent of contamination cannot be } \\
\text { accurately determined. }\end{array}$ \\
\hline $\begin{array}{l}\text { Clean Closure } \\
\text { Completeness }\end{array}$ & $\begin{array}{l}100 \% \text { of targeted contaminants have valid } \\
\text { results. }\end{array}$ & $\begin{array}{l}\text { Cannot determine whether COCs remain in } \\
\text { soil. }\end{array}$ \\
\hline $\begin{array}{l}\text { CAS }=\text { Corrective action si } \\
\text { COC }=\text { Contaminant of cor } \\
\text { COPC }=\text { Contaminant of } p\end{array}$ & $\begin{array}{l}\text { ND }=\text { Normaliz } \\
\text { RPD = Relativ }\end{array}$ & $\begin{array}{l}\text { tion level } \\
\text { ed difference } \\
\text { e percent difference }\end{array}$ \\
\hline
\end{tabular}

$\mathrm{DQO}=$ Data quality objective

\subsubsection{Precision}

Precision is a measure of the repeatability of the analysis process from sample collection through analysis results. It is used to assess the variability between two equal samples.

Determinations of precision will be made for field duplicate samples and laboratory duplicate samples. Field duplicate samples will be collected simultaneously with samples from the same 
source under similar conditions in separate containers. The duplicate sample will be treated independently of the original sample in order to assess field impacts and laboratory performance on precision through a comparison of results. Laboratory precision is evaluated as part of the required laboratory internal QC program to assess performance of analytical procedures. The laboratory sample duplicates are an aliquot, or subset, of a field sample generated in the laboratory. They are not a separate sample but a split, or portion, of an existing sample. Typically, laboratory duplicate QC samples may include matrix spike duplicate (MSD) and laboratory control sample (LCS) duplicate samples for organic, inorganic, and radiological analyses.

Precision is a quantitative measure used to assess overall analytical method and field-sampling performance as well as to assess the need to "flag" (qualify) individual parameter results when corresponding QC sample results are not within established control limits.

The criteria used for the assessment of chemical precision when both results are greater than or equal to $5 \mathrm{x}$ reporting limit (RL) is 20 percent and 35 percent for aqueous and soil samples, respectively. When either result is less than 5x RL, a control limit of $\pm 1 x R L$ and $\pm 2 x$ RL for aqueous and soil samples, respectively, is applied to the absolute difference.

The criteria used for the assessment of radiological precision when both results are greater than or equal to 5x MDC is 20 percent and 35 percent for aqueous and soil samples, respectively. When either result is less than 5x MDC, the normalized difference (ND) should be between -2 and +2 for aqueous and soil samples. The parameters to be used for assessment of precision for duplicates are listed in Table 3-5.

Any values outside the specified criteria do not necessarily result in the qualification of analytical data. It is only one factor in making an overall judgment about the quality of the reported analytical results. The performance metric for assessing the DQI of precision on DQO decisions (Table 6-1) is that at least 80 percent of sample results for each measured contaminant are not qualified due to duplicates exceeding the criteria. If this performance is not met, an assessment will be conducted in the investigation report on the impacts to DQO decisions specific to affected contaminants and CASs. 


\subsubsection{Accuracy}

Accuracy is a measure of the closeness of an individual measurement to the true value. It is used to assess the performance of laboratory measurement processes.

Accuracy is determined by analyzing a reference material of known parameter concentration or by reanalyzing a sample to which a material of known concentration or amount of parameter has been added (spiked). Accuracy will be evaluated based on results from three types of spiked samples: matrix spike (MS), LCS, and surrogates (organics). The LCS sample is analyzed with the field samples using the same sample preparation, reagents, and analytical methods employed for the samples. One LCS will be prepared with each batch of samples for analysis by a specific measurement.

The criteria used for the assessment of inorganic chemical accuracy are 75 to 125 percent for MS recoveries and 80 to 120 percent for LCS recoveries. For organic chemical accuracy, MS and LCS laboratory-specific percent recovery criteria developed and generated in-house by the laboratory according to approved laboratory procedures are applied. The criteria used for the assessment of radiochemical accuracy are 80 to 120 percent for LCS and MS recoveries.

Any values outside the specified criteria do not necessarily result in the qualification of analytical data. It is only one factor in making an overall judgment about the quality of the reported analytical results. Factors beyond laboratory control, such as sample matrix effects, can cause the measured values to be outside of the established criteria. Therefore, the entire sampling and analytical process may be evaluated when determining the usability of the affected data.

The performance metric for assessing the DQI of accuracy on DQO decisions (Table 6-1) is that at least 80 percent of the sample results for each measured contaminant are not qualified for accuracy. If this performance is not met, an assessment will be conducted in the investigation report on the impacts to DQO decisions specific to affected contaminants and CASs.

\subsubsection{Representativeness}

Representativeness is the degree to which sample characteristics accurately and precisely represent a characteristics of a population or an environmental condition (EPA, 2002). Representativeness is 
assured by carefully developing the sampling strategy during the DQO process such that false negative and false positive decision errors are minimized. The criteria listed in DQO Step 6 - Specify the Tolerable Limits on Decision Errors are:

- For Decision I judgmental sampling, having a high degree of confidence that the sample locations selected will identify COCs if present anywhere within the CAS.

- Having a high degree of confidence that analyses conducted will be sufficient to detect any COCs present in the samples.

- For Decision II, having a high degree of confidence that the sample locations selected will identify the extent of COCs.

These are qualitative measures that will be used to assess measurement system performance for representativeness. The assessment of this qualitative criterion will be presented in the investigation report.

\subsubsection{Completeness}

Completeness is defined as generating sufficient data of the appropriate quality to satisfy the data needs identified in the DQOs. For judgmental sampling, completeness will be evaluated using both a quantitative measure and a qualitative assessment. The quantitative measurement to be used to evaluate completeness is presented in Table 6-1 and is based on the percentage of measurements made that are judged to be valid.

For the judgmental sampling approach, the completeness goal for targeted contaminants and the remaining COPCs is 100 and 80 percent, respectively. If this goal is not achieved, the dataset will be assessed for potential impacts on making DQO decisions.

The qualitative assessment of completeness is an evaluation of the sufficiency of information available to make DQO decisions. This assessment will be based on meeting the data needs identified in the DQOs and will be presented in the investigation report. Additional samples will be collected if it is determined that the number of samples do not meet completeness criteria. 


\subsubsection{Comparability}

Comparability is a qualitative parameter expressing the confidence with which one dataset can be compared to another (EPA, 2002). The criteria for the evaluation of comparability will be that all sampling, handling, preparation, analysis, reporting, and data validation were performed using approved standard methods and procedures. This will ensure that data from this project can be compared to regulatory action levels that were developed based on data generated using the same or comparable methods and procedures. An evaluation of comparability will be presented in the investigation report.

\subsubsection{Sensitivity}

Sensitivity is the capability of a method or instrument to discriminate between measurement responses representing different levels of the variable of interest (EPA, 2002). The evaluation criteria for this parameter will be that measurement sensitivity (detection limits) will be less than or equal to the corresponding FALs. If this criterion is not achieved, the affected data will be assessed for usability and potential impacts on meeting site characterization objectives. This assessment will be presented in the investigation report. 


\subsection{Duration and Records Availability}

\subsection{Duration}

Table 7-1 is a tentative duration of activities (in calendar days) for corrective action investigation activities.

Table 7-1

Corrective Action Investigation Activity Durations

\begin{tabular}{|c|c|}
\hline Duration (days) & Activity \\
\hline \hline 10 & Site Preparation \\
\hline 76 & Field Work Preparation and Mobilization \\
\hline 20 & Sampling \\
\hline 160 & Data Assessment \\
\hline 180 & Waste Management \\
\hline
\end{tabular}

\subsection{Records Availability}

Historic information and documents referenced in this plan are retained in the NNSA/NSO project files in Las Vegas, Nevada, and can be obtained through written request to the NNSA/NSO Project Manager. This document is available in the DOE public reading rooms located in Las Vegas and Carson City, Nevada, or by contacting the appropriate DOE Project Manager. The NDEP maintains the official Administrative Record for all activities conducted under the auspices of the FFACO. 


\subsection{References}

ASTM, see American Society for Testing and Materials.

American Society for Testing and Materials. 1995. Standard Guide for Risk-Based Corrective Action Applied at Petroleum Release Sites/American Society for Testing and Materials, ASTM E 1739-95 (Reapproved 2002). Philadelphia, PA.

American Society for Testing and Materials. 2000. Standard Test Method for Radiochemical Determination of Uranium Isotopes in Soil by Alpha Spectrometry, ASTM C 1000-00. West Conshohocken, PA: ASTM International.

American Society for Testing and Materials. 2002. Standard Test Method for Radiochemical Determination of Plutonium in Soil by Alpha Spectroscopy, ASTM C 1001-00.

West Conshohocken, PA: ASTM International.

BN, see Bechtel Nevada.

Bechtel Nevada. 1995. Nevada Test Site Performance Objective for Certification of Nonradioactive Hazardous Waste, Rev. 0, G-E11/96.01. Las Vegas, NV.

CFR, see Code of Federal Regulations.

Code of Federal Regulations. 2003a. Title 40 CFR, Parts 761, "Polychlorinated Biphenyls (PCBs) Manufacturing, Processing, Distribution in Commerce, and Use Prohibitions.” Washington, DC: U.S. Government Printing Office.

Code of Federal Regulations. 2003b. Title 40 CFR, Part 763, “Asbestos.” Washington, DC:

U.S. Government Printing Office.

Code of Federal Regulations. 2006. Title 40 CFR, Parts 260-282, "Hazardous Waste Management System: General.” Washington, DC: U.S. Government Printing Office.

DOE, see U.S. Department of Energy.

DOE/NV, see U.S. Department of Energy, Nevada Operations Office.

DRI, see Desert Research Institute.

Desert Research Institute. 1988. CERCLA Preliminary Assessment of DOE's Nevada Operations Office, Nuclear Weapons Testing Areas. April. Las Vegas, NV.

EPA, see U.S. Environmental Protection Agency. 
ERDA, see U.S. Energy Research and Development Administration.

EG\&G Rocky Flats. 1991. General Radiochemistry and Routine Analytical Services Protocol (GRASP), Version 2.1. July. Golden, CO: Environmental Management Department.

FFACO, see Federal Facility Agreement and Consent Order.

Federal Facility Agreement and Consent Order. 1996 (as amended). Agreed to by the State of Nevada, the U.S. Department of Energy, and the U.S. Department of Defense.

Fenix and Sisson, Inc. Date Unknown. Water Well C Records. U.S. Atomic Energy Commission.

Moore, J., Science Applications International Corporation. 1999. Memorandum to M. Todd (SAIC) entitled, “Background Concentrations for NTS and TTR Soil Samples,” 3 February. Las Vegas, NV: IT Corporation.

Murphy, T., Bureau of Federal Facilities. 2004. Letter to R. Bangerter (NNSA/NSO) entitled, "Review of Industrial Sites Project Document Guidance for Calculating Industrial Sites Project Remediation Goals for Radionuclides in Soil Using the Residual Radiation (RESRAD) Computer Code,” 19 November. Las Vegas, NV.

NAC, see Nevada Administrative Code.

NBMG, see Nevada Bureau of Mines and Geology.

NCRP, see National Council on Radiation Protection and Measurements.

NDEP, see Nevada Division of Environmental Protection.

NNSA/NSO, see U.S. Department of Energy, National Nuclear Security Administration Nevada Site Office.

NNSA/NV, see U.S. Department of Energy, National Nuclear Security Administration Nevada Operations Office.

NOAA, see National Oceanic and Atmospheric Administration.

NRS, see Nevada Revised Statutes.

National Council on Radiation Protection and Measurements. 1999. Recommended Screening Limits for Contaminated Surface Soil and Review of Factors Relevant to Site-Specific Studies/National Council on Radiation Protection and Measurements, NCRP Report No. 129. Bethesda, MD.

National Oceanic and Atmospheric Administration. 2002. “Precipitation Summary.” As accessed at http://www.sord.nv.doe.gov/home_climate.htm on 5 June 2006. 
Nevada Administrative Code. 2006a. NAC 444, "Sanitation.” Carson City, NV. As accessed at http://www.leg.state.nv.us/nac on 15 June.

Nevada Administrative Code. 2006b. NAC 445A, “Water Controls.” Carson City, NV. As accessed at http://www.leg.state.nv.us/nac on 15 June.

Nevada Bureau of Mines and Geology. 1998. Mineral and Energy Resource Assessment of the Nellis Air Force Range, Open-File Report 98-1. Reno, NV.

Nevada Division of Environmental Protection. 1995. Mutual Consent Agreement between the State of Nevada and the U.S. Department of Energy for the Storage of Low-Level Land Disposal Restricted Mixed Waste. Carson City, NV.

Nevada Division of Environmental Protection. 1997a. Class II Solid Waste Disposal Site for Municipal and Solid Waste, Area 23 of the NTS, Permit SW 13-097-04. Carson City, NV.

Nevada Division of Environmental Protection. 1997b (as amended in August 2000). Class III Solid Waste Disposal Site for Hydrocarbon Burdened Soils, Area 6 of the NTS, Permit SW 1309702. Carson City, NV.

Nevada Division of Environmental Protection. 1997c (as amended in August 2000). Class III Solid Waste Disposal Site; UIOC, Area 9 of the NTS, Permit SW 13-097-03. Carson City, NV.

Nevada Division of Environmental Protection. 1999. State of Nevada Water Pollution Control General Permit, No. GNEV93001. Carson City, NV.

Nevada Division of Environmental Protection. 2000. Nevada Test Site Permit for Hazardous Waste Management Facility (NEV HW0009). Las Vegas, NV.

Nevada Revised Statutes. 2005a. NRS 444.440 - 444.620, “Collection and Disposal of Solid Waste.” Carson City, NV.

Nevada Revised Statutes. 2005b. NRS 459.400 - 459.600, “Disposal of Hazardous Waste.” Carson City, NV.

Nevada Revised Statutes. 2005c. NRS 618.750 - 618.840, “Disposal of Hazardous Waste.” Carson City, NV.

Paar, J.G., and D.R. Porterfield. 1997. Evaluation of Radiochemical Data Usability, ES/ER/MS-5. April. Oak Ridge, TN: U.S. Department of Energy.

REECo, see Reynolds Engineering \& Electrical Co., Inc.

Reynolds Electrical \& Engineering Co., Inc. 1991. Nevada Test Site Inventory of Inactive and Abandoned Facilities and Waste Sites, DOE/NV/10630-18. U.S. Department of Energy. 
Shott, G.J., V. Yucel, M.J. Sully, L.E. Barker, S.E. Rawlinson, and B.A. Moore. 1997. Performance Assessment/Composite Analysis for the Area 3 Radioactive Waste Management Site at the Nevada Test Site, Nye County, Nevada, Rev. 2.0. Las Vegas, NV.

USC, see United State Code.

USGS, see U.S. Geological Survey.

USGS and DOE, see U.S. Geological Survey and U.S. Department of Energy.

United States Code. 1976. 15 USC 2601 et seq., “Toxic Substances Control Act.” Enacted by Public Law No. 94-469, as amended. Washington, DC: U.S. Government Printing Office.

U.S. Department of Energy. 1993. Radiation Protection of the Public and the Environment, DOE Order 5400.5, Change. 2. Washington, DC: U.S. Government Printing Office.

U.S. Department of Energy. 1997. The Procedures Manual of the Environmental Measurements Laboratory, HASL-300, 28th Ed., Vol. I. New York, NY.

U.S. Department of Energy, National Nuclear Security Administration Nevada Operations Office. 2002a. Industrial Sites Quality Assurance Project Plan, Nevada Test Site, Nevada, Rev. 3, DOE/NV--372. Las Vegas, NV.

U.S. Department of Energy, National Nuclear Security Administration Nevada Operations Office. 2002b. Underground Test Area Project Waste Management Plan, DOE/NV--343-Rev. 2. Las Vegas, NV.

U.S. Department of Energy, National Nuclear Security Administration Nevada Site Office. 2004. NV/YMP Radiological Control Manual, Rev. 5, DOE/NV/11718-079, UC-702. Prepared by A.L. Gile of Bechtel Nevada. Las Vegas, NV.

U.S. Department of Energy, National Nuclear Security Administration Nevada Site Office. 2006a. Industrial Sites Project Establishment of Final Action Levels, DOE/NV--1107, Rev. 0. Las Vegas, NV.

U.S. Department of Energy, National Nuclear Security Administration Nevada Site Office. 2006b. Nevada Test Site Waste Acceptance Criteria, DOE/NV--325, Rev. 6-02. Las Vegas, NV.

U.S. Department of Energy, Nevada Operations Office. 1992. Remedial Investigation and Feasibility Study for the Plutonium Contaminated Soils at Nevada Test Site, Nellis Air Force Range and Tonopah Test Range. April. Las Vegas, NV.

U.S. Department of Energy, Nevada Operations Office. 1996. Final Environmental Impact Statement for the Nevada Test Site and Off-Site Locations in the State of Nevada, DOE/EIS 0243. Las Vegas, NV. 
U.S. Department of Energy, Nevada Operations Office. 1997. Integrated Safety Management Policy, DOE Order NV P 450.4. Las Vegas, NV.

U.S. Department of Energy, Nevada Operations Office. 1998. Nevada Test Site Resource Management Plan, DOE/NV--518, Las Vegas, NV.

U.S. Department of Energy, Nevada Operations Office. 1999. RCRA Part B Permit (NEV HW0021) Application for Waste Management Activities at the Nevada Test Site. Las Vegas, NV.

U.S. Energy Research and Development Administration. 1977. Final Environmental Impact Statement, Nevada Test Site, Nye County, Nevada, ERDA-1551, Washington, DC.

U.S. Environmental Protection Agency. 1988. Contract Laboratory Program Statement of Work for Inorganic Analysis, SOW No. 788, EPA/540/R-94/093. Washington, DC.

U.S. Environmental Protection Agency. 1994. Contract Laboratory Program Statement of Work for Inorganic Analysis, ILMO 3.0, EPA/540/R-94/076. Washington, DC.

U.S. Environmental Protection Agency. 1995. Contract Laboratory Program Statement of Work for Inorganic Analysis, ILMO 4.0, EPA/540/R-95/121. Washington, DC.

U.S. Environmental Protection Agency. 1996. Test Method for Evaluating Solid Waste Physical/Chemical Methods, SW-846, 3rd Edition. Washington, DC.

U.S. Environmental Protection Agency. 1999. Contract Laboratory Program Statement of Work for Organic Analysis, OCM 04.3. Washington, DC.

U.S. Environmental Protection Agency. 2002. Guidance for Quality Assurance Project Plans, EPA QA/G5. Washington, DC.

U.S. Environmental Protection Agency. 2004. Region 9 Preliminary Remediation Goals (PRGs). As accessed at http://www.epa.gov/region09/waste/sfund/prg/index.htm on 16 May 2006. Prepared by S.J. Smucker. San Francisco, CA.

U.S. Geological Survey. 1990. Geologic Map of the Nevada Test Site, Southern Nevada, USGS Map I-2046. Denver, CO.

U.S. Geological Survey. 1996. Summary of Hydrogeological Controls on Groundwater Flow at the Nevada Test Site, Nye County, Nevada, USGS WRIR 96-4109. Prepared by R.J. Laczniak, J.C. Cole, D.A. Sawyer, and D.A. Trudeau.

U.S. Geological Survey and U.S. Department of Energy. 2006. "USGS/USDOE Cooperative Studies in Nevada Periodic Water Levels -- Nevada Test Site Map.” As accessed at http://nevada.usgs.gov/doe_nv/doe_nv/ntsmap.htm on 2 February. 
Winograd, I.J., and W. Thordarson. 1975. Hydrology and Hydrochemical Framework, South-Central Great Basin, Nevada-California, with Special Reference to the Nevada Test Site, USGS Professional Paper 712-C. Denver, CO.

Winograd, I.J., and R.A. Young. 1965. Hydrologic Maps of the Nevada Test Site and Vicinity. U.S. Geological Survey. 


\section{Appendix A}

\section{Data Quality Objectives}




\section{A.1.0 Introduction}

The DQO process described in this appendix is a seven-step strategic, systematic planning method used to plan data collection activities and define performance criteria for the CAU 190, Contaminated Waste Sites, field investigation. The DQOs are designed to ensure that the data collected will provide sufficient and reliable information to identify, evaluate, and technically defend recommended corrective actions (i.e., no further action, closure in place, or clean closure). Existing information about the nature and extent of contamination in CAU 190 CASs is insufficient to evaluate and select preferred corrective actions; therefore, a CAI will be conducted.

The CAU 190 investigation will be based on the DQOs presented in this appendix as developed by representatives of NDEP and the NNSA/NSO. The seven steps of the DQO process presented in Sections A.3.0 through A.9.0 were developed in accordance with EPA Guidance on Systematic Planning using the Data Quality Objectives Process (EPA, 2006).

The DQO process presents a judgmental sampling approach. In general, the procedures used in the DQO process provide:

- A method to establish performance or acceptance criteria, which serve as the basis for designing a plan for collecting data of sufficient quality and quantity to support the goals of a study.

- Criteria used to establish the final data collection design such as:

- The nature of the problem to initiate the study and a conceptual model of the environmental hazard to be investigated.

- The decisions or estimates that need to be made and order of priority to resolve them.

- $\quad$ The type of data needed.

- An analytic approach or decision rule that defines the logic for how the data will be used to draw conclusions from the study findings.

- Acceptable quantitative criteria on the quality and quantity of the data to be collected, relative to the ultimate use of the data. 
- A data collection design that will generate data meeting the quantitative and qualitative criteria specified. A data collection design specifies the type, number, location, and physical quantity of samples and data, as well as the QA and QC activities, that ensure sampling design and measurement errors are managed sufficiently, to meet the performance or acceptance criteria specified in the DQOs. 


\section{A.2.0 Background Information}

The following four CASs that comprise CAU 190 are located in Areas 11 and 14 of the NTS, as shown in Figure A.2-1. The three CASs within the Tweezer Facility are shown in Figure A.2-2.

- 11-02-01, Underground Centrifuge

- 11-02-02, Drain Lines and Outfall

- 11-59-01, Tweezer Facility Septic System

- 14-23-01, LTU-6 Test Area

Sections A.2.1 through A.2.4 provide a CAS description, physical setting and operational history, release information, and previous investigation results for each CAU 190 CAS. The CAS-specific COPCs are provided in the following sections. Many of the COPCs are based on a conservative evaluation of possible site activities considering the incomplete site histories of the CASs and considering contaminants found at similar NTS sites. Targeted contaminants are defined as those that are known or could be reasonably suspected to be present within the CAS based on previous sampling or process knowledge.

\section{A.2.1 Corrective Action Site 11-02-01, Underground Centrifuge}

Corrective Action Site 11-02-01 consists of potential soil contamination originating from an underground centrifuge located at the Tweezer Facility in Area 11 of the NTS. According to DRI, the centrifuge is a historically significant object at the NTS. Figure A.2-3 shows a site sketch of the CAS.

Physical Setting and Operational History - Corrective Action Sites 11-02-01, 11-02-02, and 11-59-01 are located within the Tweezer Facility in the Yucca Flat Hydrographic Area of the NTS. Section 2.1 contains additional information on the physical setting.

The specific activities conducted at the Tweezer Facility are classified. According to interviewees, weapons components were disassembled at the Tweezer Facility. The centrifuge was built to provide an acceleration environment for test units that may have contained explosives. The centrifuge was designed and first used in 1972. Hydraulic fluid for the centrifuge was circulated through a pair of high-pressure hoses from a nearby pump house. There was no electrical power in the centrifuge, so 


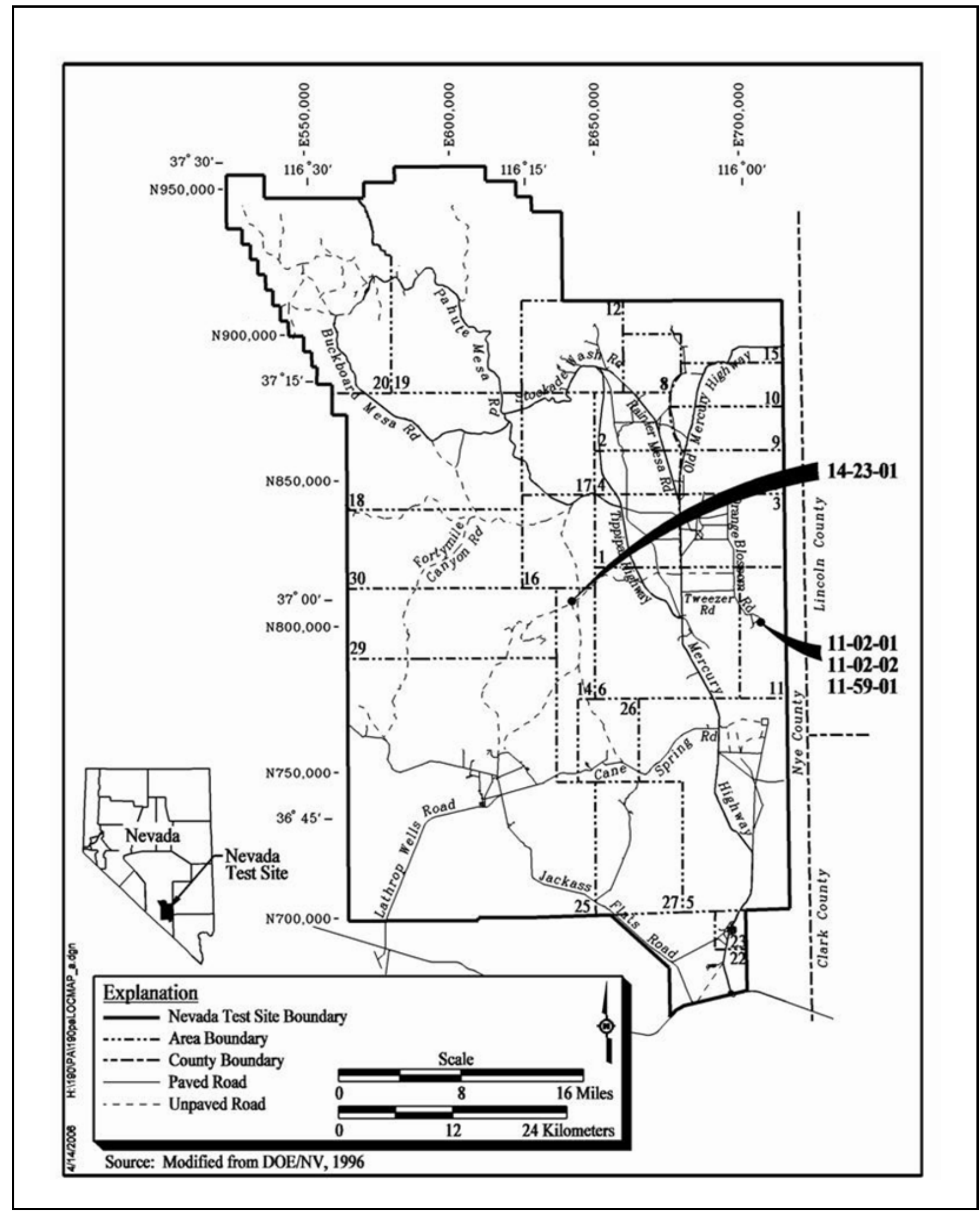

Figure A.2-1

Corrective Action Unit 190, CAS Location Map 


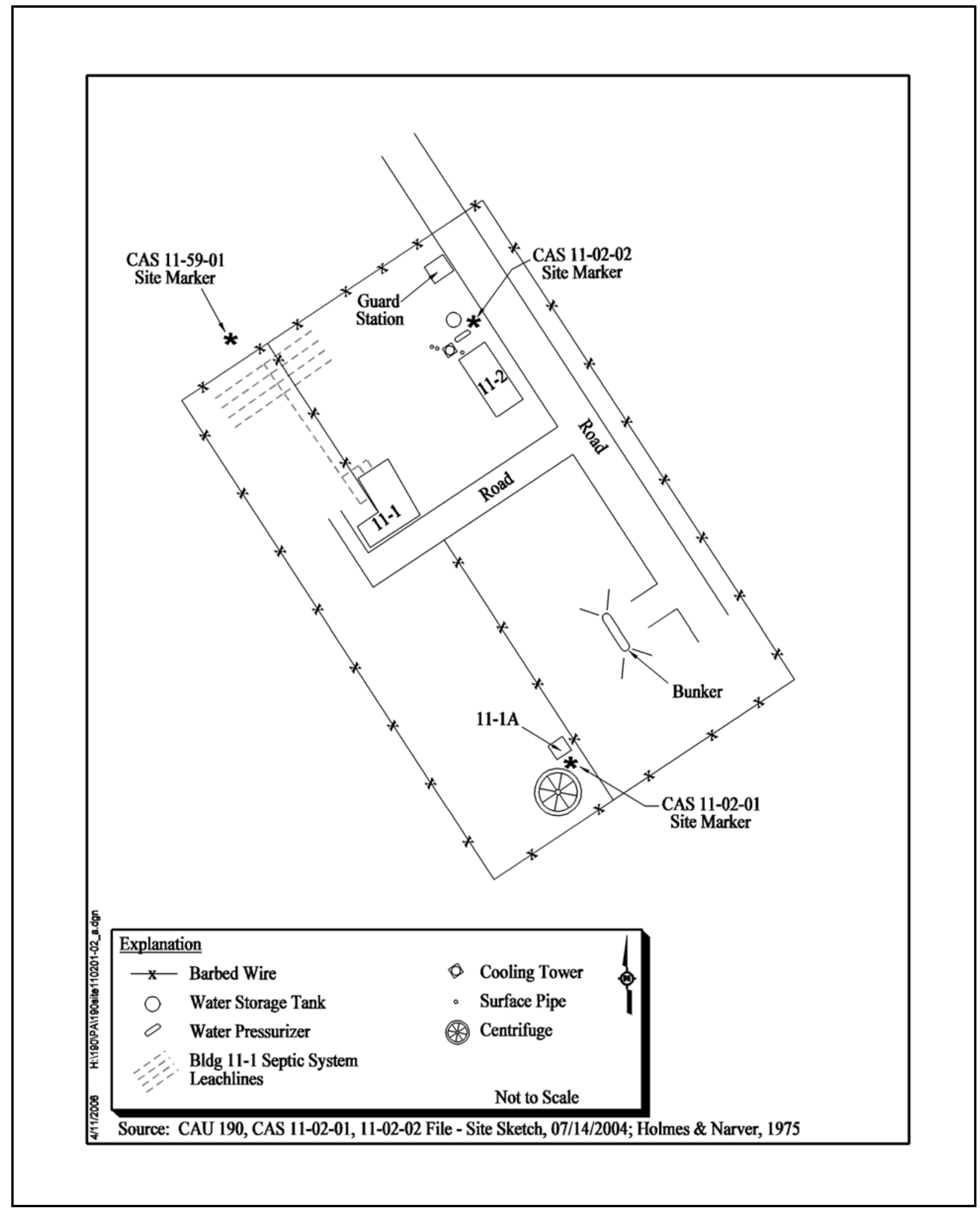

Figure A.2-2

Corrective Action Unit 190 CASs Within the Tweezer Facility 


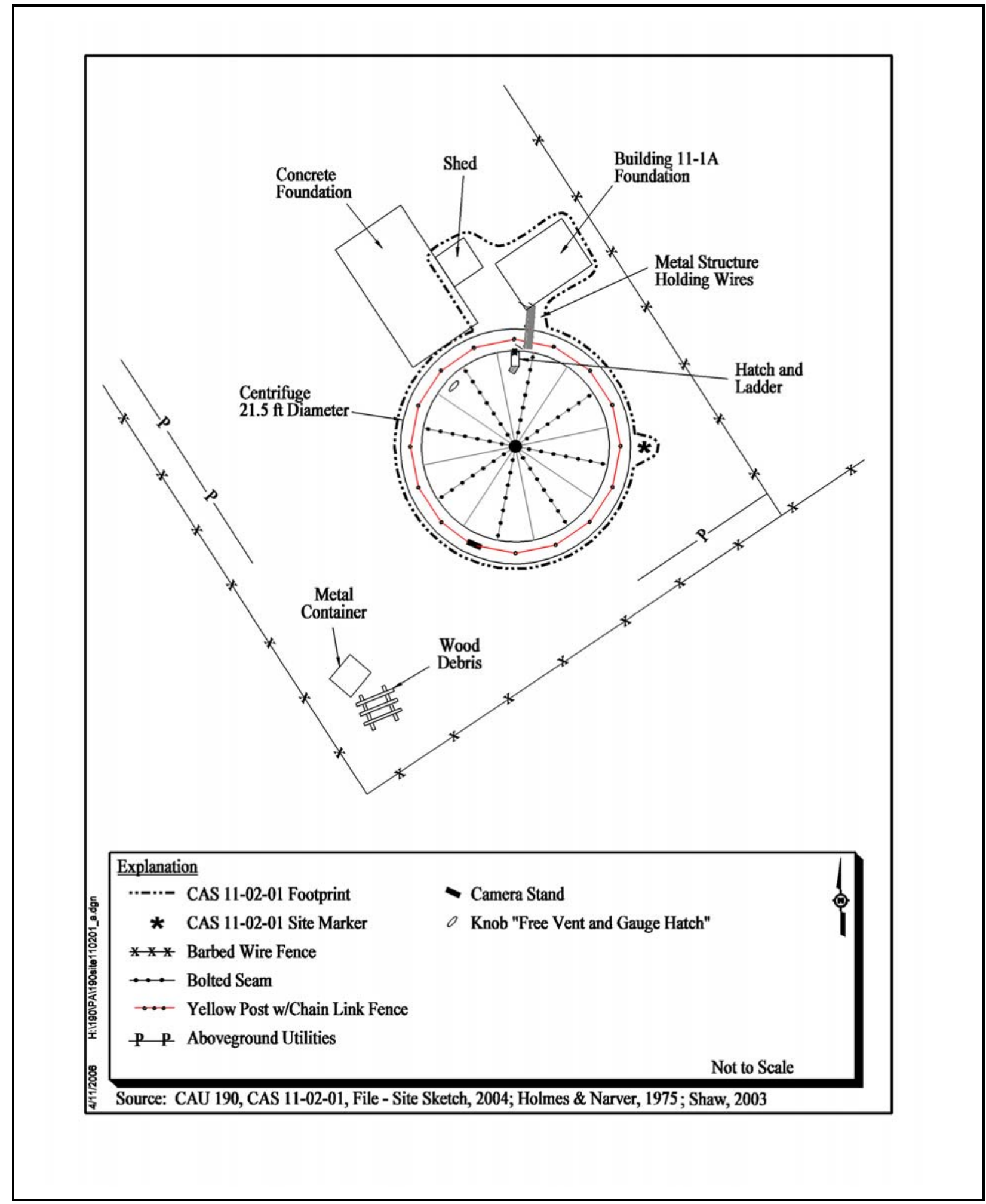

Figure A.2-3

Site Sketch of CAS 11-02-01, Underground Centrifuge 
the electric pump in the pump house (Building 11-1A) was powered by a nearby motor generator. Remote controls for the centrifuge were located in the disassembly and x-ray room of Building 11-1. After centrifuge operation for a test was completed, the centrifuge was dismantled and critical parts were cleaned and stored. Buildings 11-1 and 11-1A were demolished in 2004.

The centrifuge is $21.5 \mathrm{ft}$ in diameter and $7.5 \mathrm{ft}$ deep. A circular concrete pad surrounds the centrifuge, and the top is covered with a removable metal lid with an access hatch. The inside of the centrifuge contains a spindle and drainpipe connecting to a 5- by 5- by 3-ft gravel-filled drain sump in the floor of the centrifuge. The centrifuge is surrounded by a chain fence. Two hoses (a fluid supply line and a fluid return line) connected the motor and gearbox inside the centrifuge to the pump house located approximately $15 \mathrm{ft}$ away. The hydraulic hoses are still connected to the drive on the bottom of the centrifuge pit. The other ends of the hoses still have the quick disconnect fittings intact and are lying on the ground near the centrifuge.

Release Information - There is a potential for TPH contamination of the soil from potential leakage of hydraulic fluid during operation. However, there have been no reports of leakage that occurred.

Previous Investigation Results - During a July 25, 2006, site visit, an inspection of the hoses and the entire pathway from the centrifuge drive to the end of the hoses confirmed that the hoses are intact and there was no evidence of leakage other than a small stain near the drive shaft inside the centrifuge.

\section{A.2.2 Corrective Action Site 11-02-02, Drain Lines and Outfall}

Corrective Action Site 11-02-02 consists of a cooling tower, subsurface piping, an outfall and drain line; and soil surrounding these components, located on the northeast end of the former location of Building 11-2 at the Tweezer Facility in Area 11 of the NTS. There is a potential release of contaminants from the cooling tower or Building 11-2 into the subsurface piping, drain line, outfall, and surrounding soil. Figure A.2-4 shows a site sketch of the CAS.

Physical Setting and Operational History - CAS 11-02-02 is located at the Tweezer Facility within the Yucca Flat Hydrographic Area of the NTS. Section 2.1 contains additional information on the physical setting. 


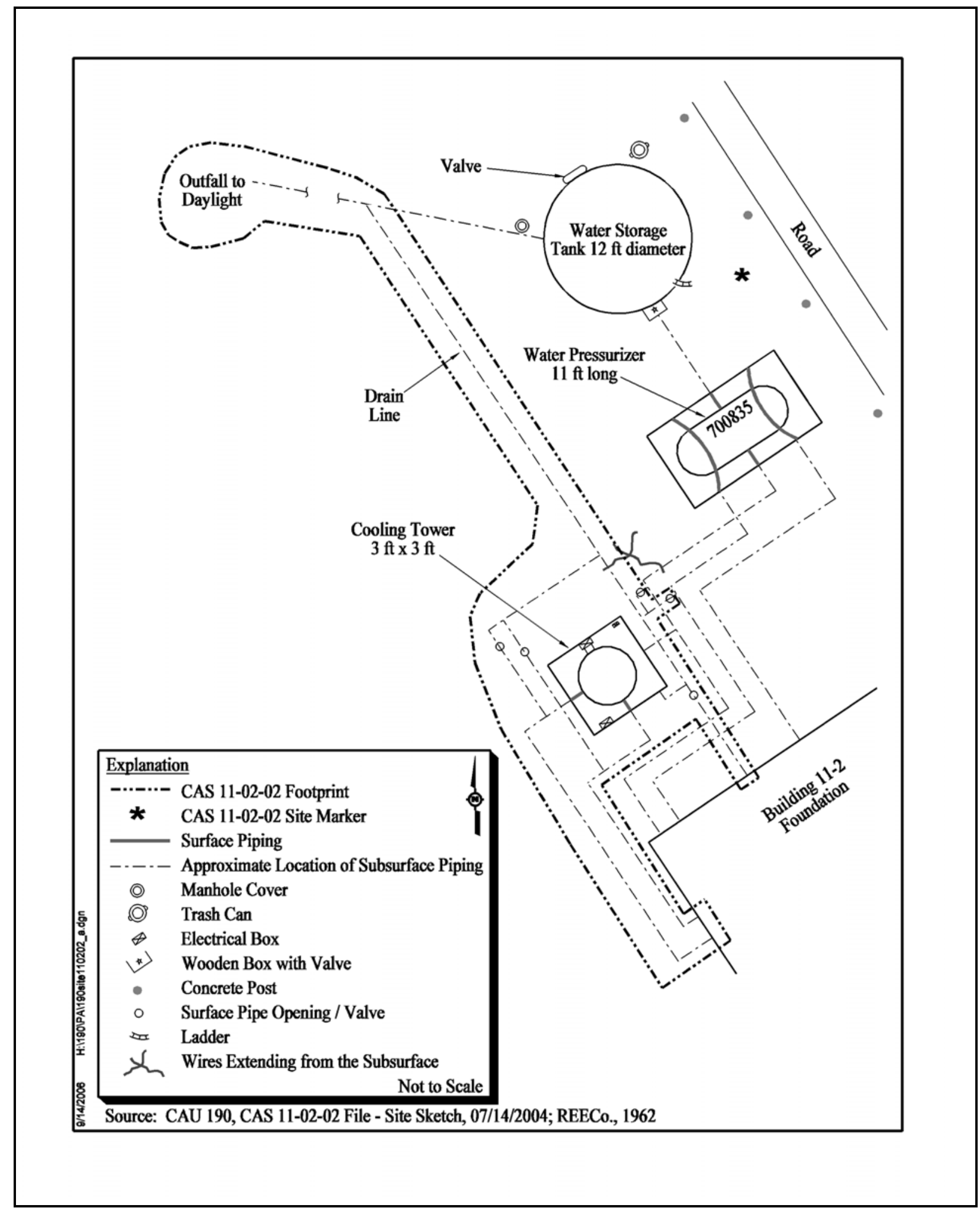

Figure A.2-4

Site Sketch of CAS 11-02-02, Drain Lines and Outfall 
The specific activities conducted at the Tweezer Facility are classified. Weapon components were delivered and disassembled at Tweezer. Building 11-2, referred to as the Tweezer Equipment Building. The building contained a battery room, gas compressor room, and mechanical equipment room. The cooling tower supplied chilled water to Building 11-2.

The cooling tower and drains from former Building 11-2 all connect to a underground pipe that leads to an outfall. The location of the oufall was located during a site visit on July 25, 2006. It is approximately $85 \mathrm{ft}$ northwest of the cooling tower.

Release Information - The cooling tower is located on a concrete pad that contains two separate electrical boxes. The cooling tower drain/blowdown line and floor drains from former Building 11-2 connect to the drain line, which leads to the outfall. The outfall also provides a discharge point for water from the water storage tank and water pressurizer tank; however, these two tanks are not included in the scope of the CAS because they only held water. An engineering drawing for Building 11-2 indicates that the outfall pipe extends northwest, downslope, from the cooling tower and Building 11-2, to drain to daylight into the surrounding soil. The end of the 3-in. pipe discharging to the outfall was located during a site visit July 25, 2006. There is a small drainage ditch down-gradient from the pipe outlet. There are no visible soil stains or other biasing factors near the outlet of the pipe into the outfall area.

Historical information indicates that water was the only fluid contained within the systems in Building 11-2. This building supplied utility services to Building 11-1. There is a potential of chromium, or some other scale inhibitors, or algicides having been used in the cooling tower.

\section{A.2.3 Corrective Action Site 11-59-01, Tweezer Facility Septic System}

Corrective Action Site 11-59-01 consists of a septic system associated with former Building 11-1 in the Tweezer Facility in Area 11 of the NTS. Former Building 11-1 at the Tweezer Facility was used to disassemble weapons components. It contained a dark room, disassembly room, x-ray room, control room, and test area. The building has been demolished, and only a concrete foundation remains. According to engineering drawings, the septic system serviced Building 11-1 and was connected to the building in three locations, one on the southwest side and two on the northwest side. Figure A.2-5 shows a site sketch of the CAS. 


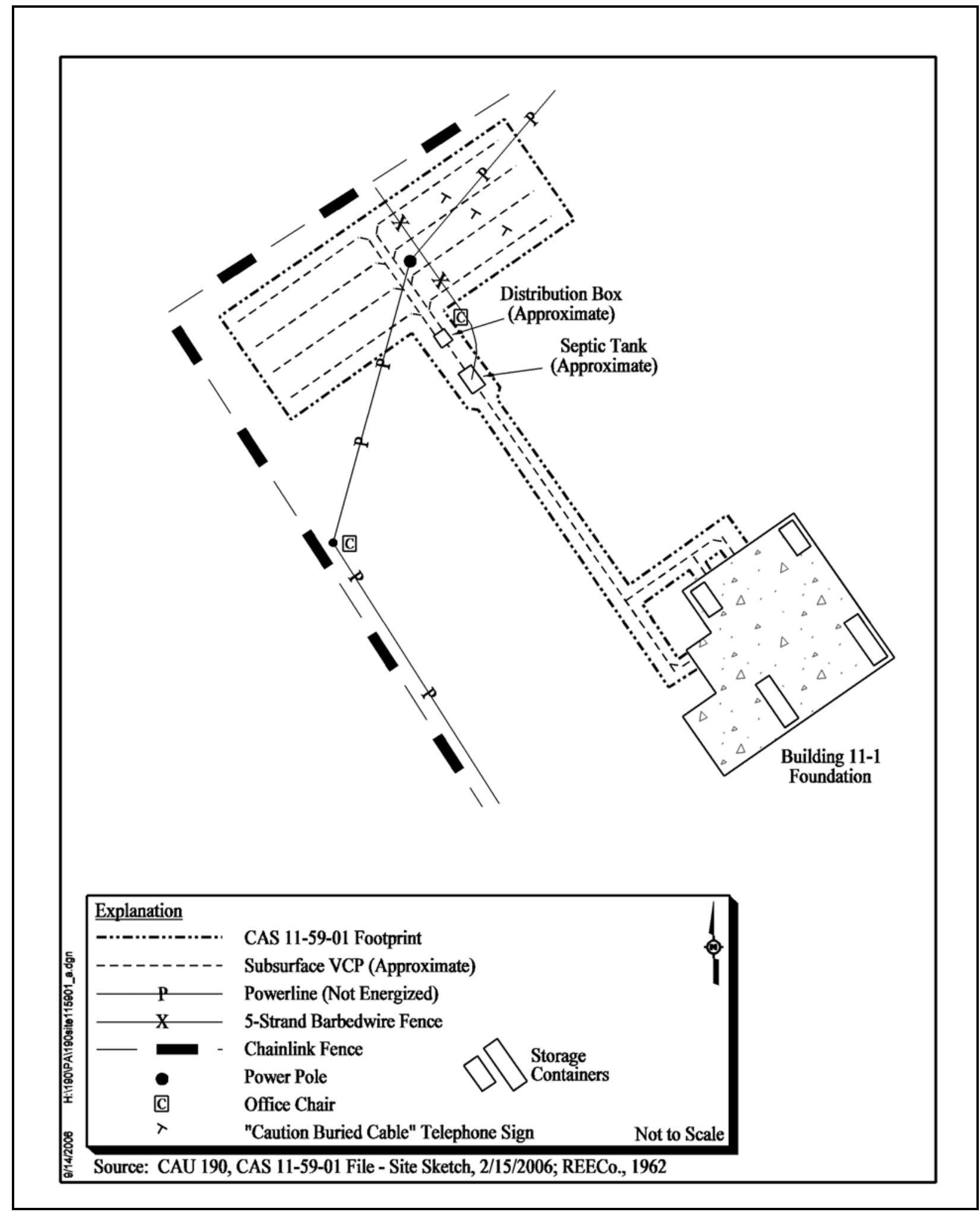

Figure A.2-5

Site Sketch of CAS 11-59-01, Tweezer Facility Septic System 
Physical Setting and Operational History - CAS 11-59-01 is located at the Tweezer Facility within the Yucca Flat Hydrographic Area of the NTS. Section 2.1 contains additional information on the physical setting. The specific activities conducted at the Tweezer Facility are classified. According to interviewees, the Tweezer Facility was used for weapons components disassembly.

Release Information - There is a potential for contamination of the soil from leakage of septic system components. Chemicals or other contaminants could have been disposed into the system from activities in Building 11-1.

\section{A.2.4 Corrective Action Site 14-23-01, LTU-6 Test Area}

Corrective Action Site 14-23-01, LTU-6 Test Area is located in Area 14 of the NTS, near the Mine Mountain Road and Mid Valley Road (Saddle Mountain Road) junction. The site is the location of the HEST area and the LTU-6 Test Area. There is a potential for TPH and uranium soil contamination from the engine generators previously located on the site and activities associated with testing conducted in the area. This site was originally identified in the document, Nevada Test Site Inventory of Inactive and Abandoned Facilities and Waste Sites (REECo, 1991).

The site is believed to have uranium contamination according to REECo (1991); however, the source of the uranium is not identified. Specific information regarding COPCs, sources of contamination, and activities that occurred at LTU-6 is uncertain due to the sensitive nature and amount of information available. However, it is known that before the LTU-6 test program, the site was used for a series of three HEST tests.

Corrective Action Site 14-23-01 consists of the soil in the LTU-6 Test Area. There was no staining observed in the test area; however, engineering drawings show that engine generators were present in the engine generator sheds located near the south end of the test area. The bunkers located in the test area housed data recording trailers that, along with the engine generators, may have contributed to a release of TPH in the test site area. It should be noted that the original REECo (1991) document suggested potentially hazardous levels of beryllium may exist. Other components at the site include a red metal shed and miscellaneous debris. Cables, wire, and wood debris are scattered around the red shed and bunker. According to a historical photograph, a sign once posted stated, "DO NOT PICK UP ANY DEBRIS IN AREA.” However, the site is not currently posted. 
Historical documents indicated a release of radiological contamination in the area. No geophysical results have been identified for this CAS.

\section{Physical Setting and Operational History}

Corrective Action Site 14-23-01 is located in the Mine Mountain Quadrangle near the southwest margin of Yucca Flat. The low range of hills in west-central Yucca Flat known as Mine Mountain exposes what is called the Mine Mountain thrust. This fault is most noticeable in the northern Mine Mountain area where, viewed from Yucca Flat on the east, prominent subhorizontal contact between red-brown clastic rocks of the Eleana Formation and overlying light gray carbonate rocks of the Sevy and Laketown Dolomites can be observed. Mine Mountain acquired its name from excavations consisting of four shallow shafts and four adits that explore parallel silicified shared zones in quartzites in the Devonian carbonate rocks (Cole and Cashman, 1997). Depth to bedrock and the existence of localized caliche and fractured rock is unknown.

The Mine Mountain region is located in the west-central and southwestern parts of the Yucca Flat where groundwater occurs within the upper clastic aquitard. The zone of saturation is more than a $1,000 \mathrm{ft}$ higher than levels in the eastern two-thirds of the valley where depth to water ranges from 1,500 to $1,885 \mathrm{ft}$ bgs. Observed hydraulic gradients indicate movement of groundwater downward through the upper clastic aquitard toward the lower carbonate aquifer. The downward flow across the various aquifers indicates good hydraulic connection between these units in the Mine Mountain Region. Once in the lower carbonate aquifer, groundwater flows from northeast to southwest. The estimated velocity of groundwater in the lower carbonate aquifer beneath Yucca Flat ranges from 0.02 to $2 \mathrm{ft}$ per day (DRI, 1988). Although there is no precipitation monitoring station at CAS 14-23-01, the average annual rainfall is estimated to be $5.0 \mathrm{in}$. (Winograd and Young, 1965). Due to the close proximity to Mine Mountain and Shoshone Mountain, this is a conservative estimate.

Release Information - There is a potential for beryllium and uranium at this site based on historical documentation; however, the source of this is not known.

Previous Investigation Results - A site visit was conducted July 25, 2006. An inspection of the area was conducted, and no stains were observed. Photographs taken are available in project files. 
This CAS is defined as the pie-shaped portion of the circular testing area shown in Figure A.9-1. Information was gathered on the Test Area during radiological surveys conducted in September and October 2006. The objective of this radiological land area surveys was to determine whether radiological contamination is present in surficial soil at concentrations statistically greater than surficial soil from undisturbed background locations. The radiological land area survey data provides useful information for preliminary health and safety assessments, support for site investigation sampling strategies, and defines the extent of potential radiological contaminants for focusing characterization efforts.

This report presents locations of radiological surface contamination and shows trends in the surface and near-surface radiological contamination concentrations.

The instruments used for this radiological land area survey were:

- $\quad$ Trimble Pathfinder Pro XRS ${ }^{\mathrm{TM}}$ GPS Receiver with TSC1 ${ }^{\mathrm{TM}}$ datalogger

- TSA Model PRM-470B Small Plastic Scintillation Detector

Certain limitations should be considered with the employed radiation detection technology. This radiation detection technology can only detect surficial and near-surficial photon radiation and some higher-energy beta radiation (only with the detector operating in an open window configuration). Alpha radiation and moderate- to low-energy beta radiation are not detected due to high susceptibility for energy loss through collision transfer.

The radiological measurements (in units of counts per second [cps]) and the survey location coordinates in Universal Transverse Mercator 11 North American Datum1927 (Western), meters were recorded for each measured point and are available in electronic format. Elevation, in mean sea level (U.S. Survey Feet), was logged with the GPS receiver to provide topography information.

The walkover radiological survey data file from the TSC1 datalogger was downloaded to a laptop computer and the GPS measurements were exported using Trimble’s Pathfinder Office ${ }^{\mathrm{TM}}$ software. Each GPS measurement was positionally corrected by collecting real-time satellite differential correction. 
Using a Kriging gridding method, ArcMap ${ }^{\mathrm{TM}}$ was then used to create a color-coded contour plot for each of the survey areas. The color-coded contour plots depict the radiological survey data (in cps) from low to high based on the following color scheme: dark blue, light blue, green, light green, yellow, light orange, orange, and red.

A total of 80,563 data points were recorded at this site with a mean undisturbed background radiation emission rate of 269 cps (Table A.2-1).

Table A.2-1

Summary of Radiological Survey Data Obtained at LTU-6 Test Area and Surrounding Area

\begin{tabular}{|c|c|}
\hline Descriptive Statistic & CAS 14-23-01 $^{\mathrm{a}}$ \\
\hline \hline Count & 80,563 \\
\hline Minimum & 107 \\
\hline Maximum & 20,255 \\
\hline Mean & 247 \\
\hline Standard Deviation & 96 \\
\hline
\end{tabular}

${ }^{a} A l l$ reading in gross counts per second

Confidence limits were calculated using the standard deviation of the survey dataset (Table A.2-2).

Table A.2-2

Summary of Confidence Limits for the Radiological Survey Data at LTU-6 Test Area

\begin{tabular}{|c|c|c|c|c|}
\hline \multirow{2}{*}{$\begin{array}{c}\text { Background } \\
\text { (counts per } \\
\text { second) }\end{array}$} & \multicolumn{3}{|c|}{ Confidence Limit (counts per second) } \\
\cline { 2 - 5 } & $\mathbf{6 8 . 0 \%}$ & $\mathbf{9 5 . 4 \%}$ & $\mathbf{9 9 . 7 \%}$ & $\mathbf{9 9 . 9 \%}$ \\
\hline \hline 269 & 290 & 304 & 327 & 334 \\
\hline
\end{tabular}

Finally, the results were plotted on a color-coded contour map (Figure A.2-6), with the different sections outlined separately. It is apparent that the majority of the area surveyed is close to background levels, while there appear to be four radiologically intense spots in Section A identified on the color-coded contour map as regions of orange and red. Anomalous spots 1, 2, and 4 may indicate surficial or near surficial material, or they may be statistical fluctuations in the data acquisition. (There is only a single data point greater than three times background for each anomaly.) 


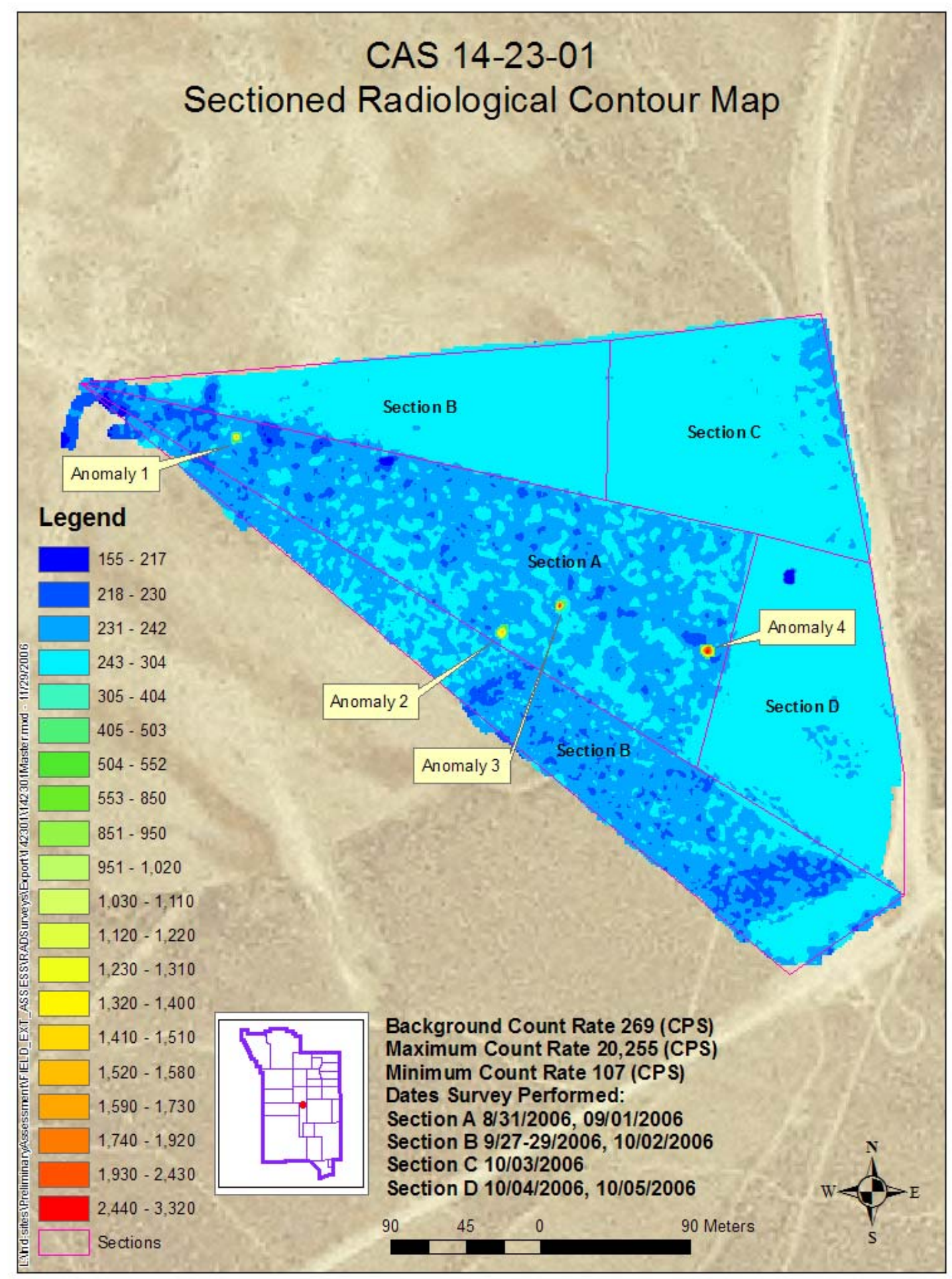

Figure A.2-6

Radiological Survey of CAS 14-23-01, LTU-6 Test Area 
Anomalous spot 3, however, indicates radiological material is present above background levels either at or below the surface. (There are several data points greater than three times background.)

\section{A.2.5 National Environmental Policy Act}

The Final Environmental Impact Statement for the Nevada Test Site and Off-Site Locations in the State of Nevada (DOE/NV, 1996) includes site investigation activities such as those proposed for CAU 190.

In accordance with the NNSA/NSO Nevada Environmental Policy Act (NEPA) Compliance Program, a NEPA checklist will be completed before site investigation activities begin at CAU 190. This checklist requires NNSA/NSO project personnel to evaluate their proposed project activities against a list of potential impacts that include, but are not limited to: air quality, chemical use, waste generation, noise level, and land use. Completion of the checklist results in a determination of the appropriate level of NEPA documentation by the NNSA/NSO NEPA Compliance Officer. This will be accomplished before mobilization for the field investigation. 


\section{A.3.0 Step 1 - State the Problem}

Step 1 of the DQO process defines the problem that requires study, identifies the planning team, and develops a conceptual model of the environmental hazard to be investigated.

The problem statement for CAU 190 is: "Existing information on the nature and extent of potential contamination is insufficient to evaluate and recommend corrective action alternatives for CAU 190 CASs.”

\section{A.3.1 Planning Team Members}

The DQO planning team consists of representatives from NDEP, NNSA/NSO, SNJV, and NSTec. The DQO planning team met on August 24, 2006. The primary decision-makers are the NDEP and NNSA/NSO representatives.

\section{A.3.2 Conceptual Site Model}

The CSM is used to organize and communicate information about site characteristics, and it reflects the best interpretation of available information at any point in time. The CSM is a primary vehicle for communicating assumptions about release mechanisms, potential migration pathways, or specific constraints. It provides a good summary of how and where contaminants are expected to move and what impacts such movement may have. It is the basis for assessing how contaminants could reach receptors both in the present and future. The CSM describes the most probable scenario for current conditions at each site and define the assumptions that are the basis for identifying appropriate sampling strategy and data collection methods. Accurate CSMs are important as they serve as the basis for all subsequent inputs and decisions throughout the DQO process.

The CSM was developed for CAU 190 using information from the physical setting, potential contaminant sources, release information, historical background information, knowledge from similar sites, and physical and chemical properties of the potentially affected media and COPCs. 
The CSM consists of:

- Potential contaminant releases including media subsequently affected.

- Release mechanisms (the conditions associated with the release).

- Potential contaminant source characteristics including contaminants suspected to be present and contaminant-specific properties.

- Site characteristics including physical, topographical, and meteorological information.

- Migration pathways and transport mechanisms that describe the potential for migration and where the contamination may be transported.

- The locations of points of exposure where individuals or populations may come in contact with a COC associated with a CAS.

- $\quad$ Routes of exposure where contaminants may enter the receptor.

If additional elements are identified during the investigation that are outside the scope of the CSM, the situation will be reviewed and a recommendation will be made as to how to proceed. In such cases, NDEP and NNSA/NSO will be notified and given the opportunity to comment on, and/or concur with, the recommendation.

The applicability of the CSM to each CAS is summarized in Table A.3-1 and discussed below. Table A.3-1 provides information on CSM elements that will be used throughout the remaining steps of the DQO process. Figure A.3-1 represents site conditions applicable to the CSM.

\section{A.3.2.1 Contaminant Release}

The most likely locations of the contamination and releases to the environment are the soils directly below or adjacent to the surface and subsurface components (i.e., septic tank, distribution box, associated underground piping, leachfield, pipe outfall and cooling tower, and ejected surface debris) of the CSM. The CSM accounts for potential releases resulting from overflow of system components that are present at the ground surface (e.g., fill pipes for septic tanks) and surface spills. Any contaminants migrating from CASs, regardless of physical or chemical characteristics, are expected to exist at interfaces, and in the soil adjacent to disposal features in lateral and vertical directions. 
Table A.3-1

\section{Conceptual Site Model Description \\ of Elements for Each CAS in CAU 190}

\begin{tabular}{|c|c|c|c|c|}
\hline CAS Identifier & $11-02-01$ & 11-02-02 & 11-59-01 & 14-23-01 \\
\hline CAS Description & $\begin{array}{l}\text { Underground } \\
\text { Centrifuge }\end{array}$ & $\begin{array}{l}\text { Drain Lines and } \\
\text { Outfall }\end{array}$ & $\begin{array}{l}\text { Tweezer } \\
\text { Facility } \\
\text { Septic } \\
\text { System }\end{array}$ & $\begin{array}{l}\text { LTU-6 Test } \\
\text { Area }\end{array}$ \\
\hline Site Status & \multicolumn{4}{|c|}{ Sites are inactive and/or abandoned } \\
\hline Exposure Scenario & \multicolumn{4}{|c|}{ Occasional } \\
\hline $\begin{array}{l}\text { Sources of Potential Soil } \\
\text { Contamination }\end{array}$ & \multicolumn{3}{|c|}{$\begin{array}{l}\text { Pipe outfall to surface and leaking pipes in subsurface. Potential } \\
\text { future contamination from septic tank, cooling tower, hydraulic } \\
\text { lines, and bricks }\end{array}$} & $\begin{array}{l}\text { Ejected } \\
\text { surface debris }\end{array}$ \\
\hline $\begin{array}{l}\text { Location of } \\
\text { Contamination/ } \\
\text { Release Point }\end{array}$ & \multicolumn{3}{|c|}{$\begin{array}{l}\text { Surface soil at or near location of outfall, subsurface soil around } \\
\text { leachfield pipe }\end{array}$} & $\begin{array}{l}\text { Surface soil } \\
\text { beneath debris }\end{array}$ \\
\hline Amount Released & \multicolumn{4}{|c|}{ Unknown } \\
\hline Affected Media & \multicolumn{4}{|c|}{ Surface and shallow subsurface soil; debris such as concrete, steel, and wood } \\
\hline Potential Contaminants & \multicolumn{4}{|c|}{ Chemical and radiological } \\
\hline Transport Mechanisms & \multicolumn{4}{|c|}{$\begin{array}{l}\text { Percolation of precipitation through subsurface media serves as the major driving } \\
\text { force for migration of contaminants. Surface water runoff may provide for the } \\
\text { transportation of some contaminants within or outside of the footprints of the CASs. }\end{array}$} \\
\hline Migration Pathways & \multicolumn{4}{|c|}{$\begin{array}{c}\text { Vertical transport expected to dominate over lateral transport due to small surface } \\
\text { gradients. }\end{array}$} \\
\hline $\begin{array}{l}\text { Lateral and Vertical } \\
\text { Extent of Contamination }\end{array}$ & \multicolumn{4}{|c|}{$\begin{array}{l}\text { Contamination, if present, is expected to be contiguous to the release points. } \\
\text { Concentrations are expected to decrease with distance and depth from the source. } \\
\text { Groundwater contamination is not expected. Lateral and vertical extent of COC } \\
\text { contamination is assumed to be within the spatial boundaries of the CAS. }\end{array}$} \\
\hline Exposure Pathways & \multicolumn{4}{|c|}{$\begin{array}{l}\text { The potential for contamination exposure is limited to industrial and construction } \\
\text { workers, and military personnel conducting training. These human receptors may be } \\
\text { exposed to COPCs through oral ingestion, inhalation, dermal contact (absorption) of } \\
\text { soil and/or debris due to inadvertent disturbance of these materials or irradiation by } \\
\text { radioactive materials. }\end{array}$} \\
\hline
\end{tabular}

$\mathrm{COC}=$ Contaminant of concern

$\mathrm{COPC}=$ Contaminant of potential concern

\section{A.3.2.2 Potential Contaminants}

The COPCs were identified during the planning process through the review of site history, process knowledge, personal interviews, past investigation efforts, and inferred activities associated with the CASs. Because complete information regarding activities performed at the CAU 190 CASs is not 


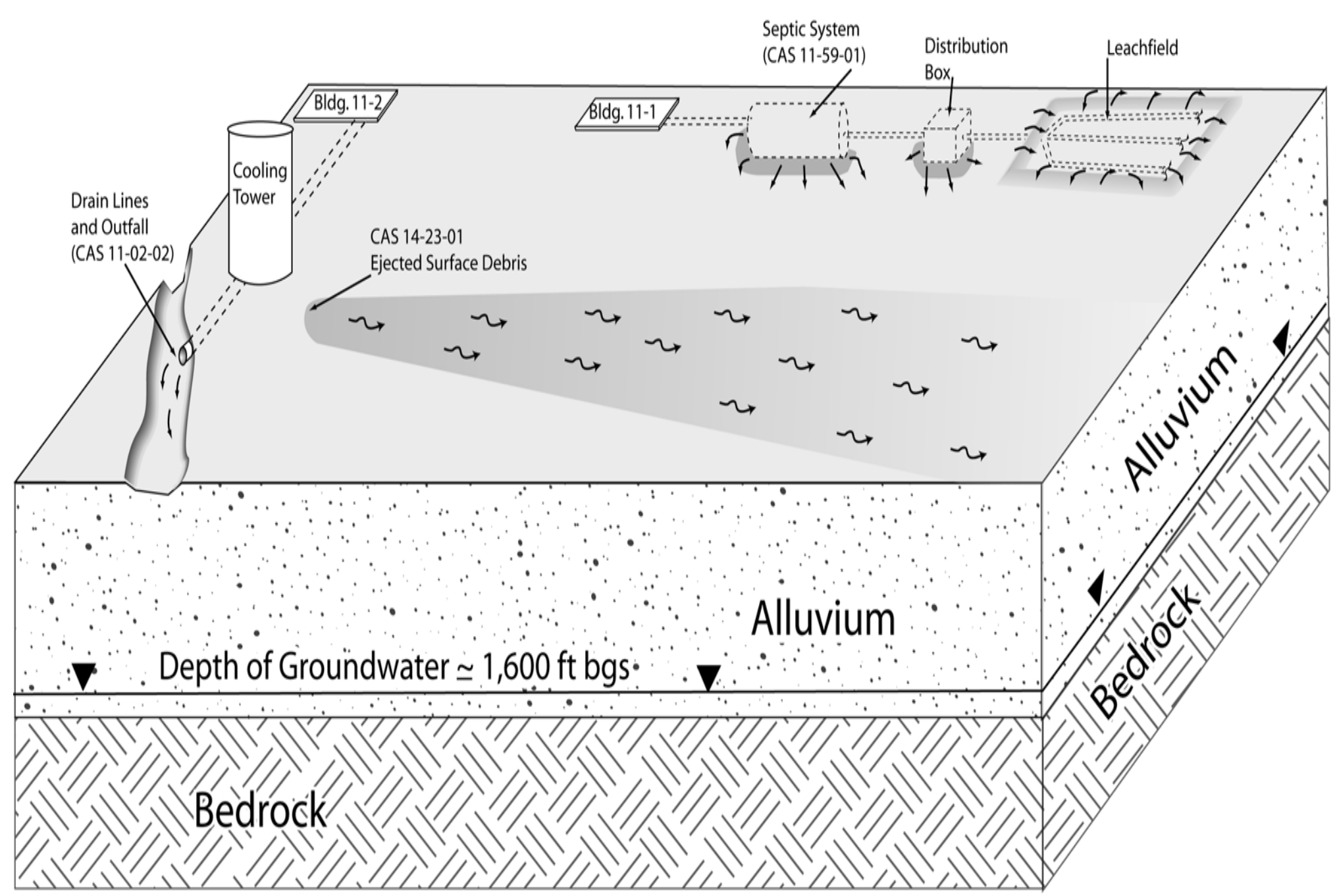

Figure A.3-1

Corrective Action Unit 190 Conceptual Site Model 
available, contaminants detected at similar NTS sites were included in the contaminant lists to reduce uncertainty. The list of COPCs is intended to encompass all of the contaminants that could potentially be present at each CAS. The COPCs applicable to Decision I environmental samples from each of the CAU 190 CASs are defined as the constituents reported from the analytical methods stipulated in Table A.3-2.

During the review of site history documentation, process knowledge, personal interviews, past investigation efforts, and inferred activities associated with the CASs, some of the COPCs were identified as targeted contaminants at specific CASs. Targeted contaminants are those COPCs for which evidence in the available site and process information suggests that they may be reasonably suspected to be present at a given CAS. The targeted contaminants are required to meet a more stringent completeness criteria than other COPCs thus providing greater protection against a decision error (Section A.3.2). Targeted contaminants for each CAU 190 CAS are identified in Table A.3-3.

\section{A.3.2.3 Contaminant Characteristics}

Contaminant characteristics include, but are not limited to solubility, density, and adsorption potential. In general, contaminants with low solubility, high affinity for media, and high density can be expected to be found relatively close to release points. Contaminants with small particle size, high solubility, low density, and/or low affinity for media are found further from release points or in low areas where evaporation of ponding will concentrate dissolved contaminants.

The following organic and inorganic constituents could be present at CAU 190. Lead compounds are adsorptive and soluble and therefore, not mobile. The solubility and mobility of TPH as a group of organic compounds is dependant upon the type of product released. Diesel oil is only slightly soluble and tends to form a viscous layer around soil particles. Uranium-238 is very immobile, moderately adsorptive, and relatively insoluble.

Previous investigations at NTS sites have shown that contaminants have not migrated significant vertical distances from the original release points. 
Table A.3-2

Analytical Program ${ }^{a}$

(Includes Waste Characterization Analyses)

\begin{tabular}{|c|c|c|c|}
\hline Analyses & w 犬্ণ & 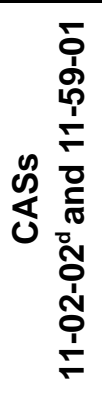 & u \\
\hline \multicolumn{4}{|c|}{ Organic Contaminants of Potential Concern (COPCs) } \\
\hline TPH-Diesel-Range Organics & $\mathrm{X}$ & $\mathrm{X}$ & \\
\hline TPH-Gasoline-Range Organics & & $\mathrm{X}$ & \\
\hline Polychlorinated Biphenyls & & $\mathrm{X}$ & \\
\hline Semivolatile Organic Compounds & & $x$ & \\
\hline Volatile Organic Compounds & & $\mathrm{X}$ & \\
\hline \multicolumn{4}{|l|}{ Pesticides } \\
\hline \multicolumn{4}{|c|}{ Inorganic COPCs } \\
\hline Explosives & & & $\mathrm{X}$ \\
\hline RCRA Metals & & $\mathrm{X}$ & $\mathrm{X}$ \\
\hline Total Beryllium & & & $\mathrm{X}$ \\
\hline \multicolumn{4}{|c|}{ Radionuclide COPCs } \\
\hline Gamma Spectroscopy & & $\mathrm{x}$ & $\mathrm{x}$ \\
\hline Isotopic Uranium & & & $\mathrm{X}$ \\
\hline \multicolumn{4}{|c|}{ Waste Characterization Analyses } \\
\hline Asbestos & & $\mathrm{X}$ & \\
\hline
\end{tabular}

${ }^{\mathrm{a}}$ The COPCs are the constituents reported from the analytical methods listed.

${ }^{b}$ Results of gamma analysis will be used to determine whether further radioanalytical analysis is warranted.

${ }^{\mathrm{c}}$ If TPH is detected at CAS 11-02-01, then analyze for PCBs, VOCs, and SVOCs.

${ }^{\mathrm{d}}$ Liquid, sludge, or scale from inside the cooling tower will only be analyzed for RCRA metals.

elf sample is collected for waste management purposes, analysis may also include Toxicity Characteristic Leaching Procedure and pesticides

$\mathrm{PCB}=$ Polychlorinated biphenyls

RCRA = Resource Conservation and Recovery Act

SVOC $=$ Semivolatile organic compound

$\mathrm{TPH}=$ Total petroleum hydrocarbons

VOC $=$ Volatile organic compound

$X=$ Required analytical method 
Table A.3-3

Targeted Contaminants for CAU 190

\begin{tabular}{|c|c|c||}
\hline $\begin{array}{c}\text { Corrective } \\
\text { Action Site }\end{array}$ & $\begin{array}{c}\text { Chemical Targeted } \\
\text { Contaminant(s) }\end{array}$ & $\begin{array}{c}\text { Radiological } \\
\text { Targeted } \\
\text { Contaminant(s) }\end{array}$ \\
\hline \hline $14-23-01$ & None & Uranium-238 \\
\hline
\end{tabular}

\section{A.3.2.4 Site Characteristics}

Site characteristics are defined by the interaction of physical, topographical, and meteorological attributes and properties. Physical properties include permeability, porosity, hydraulic conductivity, degree of saturation, sorting, chemical composition, and organic content. Topographical and meteorological properties and attributes include slope stability, precipitation frequency and amounts, precipitation runoff pathways, drainage channels and ephemeral streams, and evapotranspiration potential.

Site characteristics at CAU 190 include gentle, stable terrain that is susceptible to erosion during rain events. Surface migration is a biasing factor considered in the selection of sampling points.

\section{A.3.2.5 Migration Pathways and Transport Mechanisms}

Migration pathways include the lateral migration of potential contaminants across surface soils/sediments and vertical migration of potential contaminants through subsurface soils. Contaminants released at the Tweezer Facility and LTU-6 Test Area are subject to different transport mechanisms. Washes are generally dry but subject to infrequent, potentially intense, stormwater flows. These stormwater flow events provide an intermittent mechanism for both vertical and horizontal transport of contaminants. Contaminated sediments entrained by these stormwater events would be carried by the streamflow to locations where the flowing water loses energy and the sediments drop out. These locations are readily identifiable by hydrologists as sedimentation areas. Drainage from the Tweezer Facility is ultimately into Yucca Flat (Yucca Lake), which is located west of the site. Yucca Lake is a closed basin with no surface migration pathways off NTS.

Infiltration and percolation of precipitation serves as a driving force for downward migration of contaminants. Although there is no precipitation monitoring station at CAS 14-23-01, the average 
annual rainfall is estimated to be 5.0 in. (Winograd and Young, 1965). However, due to high potential evapotranspiration (annual potential evapotranspiration at the Area 3 Radiological Waste Management Site has been estimated at 62.6 in. [Shott et al., 1997]) and limited precipitation for this region is approximately 6 in. per year [Winograd and Thordarson, 1975]), percolation of infiltrated precipitation at the NTS does not provide a significant mechanism for vertical migration of contaminants to groundwater (DOE/NV, 1992).

The pathways for contaminant migration will be considered in the development of sampling schemes and sampling contingencies discussed in Step 7, Develop the Plan for Obtaining Data, of this appendix.

\section{A.3.2.6 Exposure Scenarios}

Human receptors may be exposed to COPCs through oral ingestion, inhalation, dermal contact (absorption) of soil or debris due to inadvertent disturbance of these materials or irradiation by radioactive materials. The land-use and exposure scenarios for the CAU 190 CASs are listed in Table A.3-4. These are based on NTS current and future land use (DOE/NV, 1998). No facilities are present that would allow these CASs to be used as an assigned work station for NTS site personnel. However, as site personnel may periodically perform work at these sites, they are considered to be remote work areas. Site workers could occupy these locations on a temporary, occasional basis such as a military exercise. Therefore, these sites are classified as occasional work areas. 
Table A.3-4

Land-Use and Exposure Scenarios

\begin{tabular}{|c|c|c|}
\hline $\begin{array}{l}\text { Corrective } \\
\text { Action Site }\end{array}$ & Record of Decision Land-Use Zone & Exposure Scenario \\
\hline $\begin{array}{c}11-02-01 \\
11-02-02, \text { and } \\
11-59-01\end{array}$ & $\begin{array}{l}\text { Reserved Zone } \\
\text { This area includes areas and facilities that provide } \\
\text { widespread flexible support for diverse short-term } \\
\text { testing and experimentation. The reserved zone is } \\
\text { also used for short-duration exercises and training, } \\
\text { such as the Nuclear Emergency Search Team and } \\
\text { Federal Radiological Monitoring and Assessment } \\
\text { Center training and U.S. Department of Defense } \\
\text { land navigation exercises and training. }\end{array}$ & \multirow{2}{*}{$\begin{array}{l}\text { Occasional Use Area } \\
\text { Worker will be exposed to the site } \\
\text { occasionally (up to } 80 \text { hours per year } \\
\text { for } 5 \text { years). Site structures are not present } \\
\text { for shelter and comfort of the worker. }\end{array}$} \\
\hline 14-23-01 & $\begin{array}{l}\text { Research Test and Experiment Zone } \\
\text { This area is designated for small-scale research } \\
\text { and development projects and demonstrations; pilot } \\
\text { projects; outdoor tests; and experiments for the } \\
\text { development, quality assurance, or reliability of } \\
\text { material and equipment under controlled conditions. } \\
\text { This zone includes compatible defense and } \\
\text { nondefense research, development, and testing } \\
\text { projects and activities. }\end{array}$ & \\
\hline
\end{tabular}




\section{A.4.0 Step 2 - Identify the Goal of the Study}

Step 2 of the DQO process states how environmental data will be used in meeting objectives and solving the problem, identifies study questions or decision statement(s), and considers alternative outcomes or actions that can occur upon answering the question(s).

\section{A.4.1 Decision Statements}

The Decision I statement is: "Is any COC present in environmental media within the CAS?" For judgmental sampling design, any analytical result for a COPC above the FAL will result in that COPC being designated as a COC. For probability (random) sampling design, any COPC that has a 95 percent upper confidence limit of the average concentration above the FAL will result in that COPC being designated as a COC. A COC may also be defined as a contaminant that, in combination with other like contaminants, is determined to jointly pose an unacceptable risk based on a multiple constituent analysis (NNSA/NSO, 2006). If a COC is detected, then Decision II must be resolved.

The Decision II statement is: "If a COC is present, is sufficient information available to evaluate potential corrective action alternatives?” Sufficient information is defined to include:

- Identifying the volume of media containing any COC bounded by analytical sample results in lateral and vertical directions.

- The information needed to characterize IDW for disposal.

A corrective action will be determined for any site containing a COC. The evaluation of the need for corrective action will include the potential for wastes that are present at a site to cause the future contamination of site environmental media if the wastes were to be released. To evaluate the potential for septic tank contents, to result in the introduction of a COC to the surrounding environmental media, the following conservative assumptions were made:

- The tank containment would fail at some point and the contents would be released to the surrounding media. 
- The resulting concentration of contaminants in the surrounding media would be equal to the concentration of contaminants in the tank waste.

- Liquid contaminant in the septic tanks exceeding the RCRA toxicity characteristic concentration can result in introduction of a COC to the surrounding media.

Sludge containing a contaminant exceeding an equivalent FAL concentration would be considered to be potential source material and would require a corrective action. Septic tank liquids with contaminant concentrations exceeding an equivalent toxicity characteristic action level would be considered to be potential source material and would require a corrective action.

If sufficient information is not available to evaluate potential corrective action alternatives then site conditions will be re-evaluated and additional samples will be collected (as long as the scope of the investigation is not exceeded and any CSM assumption has not been shown to be incorrect).

\section{A.4.2 Alternative Actions to the Decisions}

In this section the actions that may be taken to solve the problem are identified depending on the possible outcomes of the investigation.

\section{A.4.2.1 Alternative Actions to Decision I}

If no COC associated with a release from the CAS is detected, then further assessment of the CAS is not required. If a COC associated with a release from the CAS is detected, then the extent of COC contamination will be determined, and additional information required to evaluate potential corrective action alternatives will be collected.

\section{A.4.2.2 Alternative Actions to Decision II}

If sufficient information is available to evaluate potential corrective action alternatives, then further assessment of the CAS is not required. If sufficient information is not available to evaluate potential corrective action alternatives, then additional samples will be collected. 


\section{A.5.0 Step 3 - Identify Information Inputs}

Step 3 of the DQO process identifies the information needed, determines sources for information, and identifies sampling and analysis methods that will allow reliable comparisons with FALs.

\section{A.5.1 Information Needs}

To resolve Decision I (determine whether a COC is present at a given CAS), samples need to be collected and analyzed following these criteria:

- Samples must be collected in areas most likely to contain a COC (judgmental sampling)

- The analytical suite selected must be sufficient to identify any COCs present in the samples.

To resolve Decision II (determine whether sufficient information is available to evaluate potential corrective action alternatives at each CAS), samples need to be collected and analyzed to meet the following criteria:

- Samples must be collected in areas contiguous to the contamination but where contaminant concentrations are below FALs.

- Samples of the waste or environmental media must provide sufficient information to characterize the IDW for disposal.

- Samples of the waste or environmental media must provide sufficient information to determine potential remediation waste types.

- Samples of the waste in tanks must provide sufficient information to determine whether they contain potential source material.

- The analytical suites selected must be sufficient to detect contaminants at concentrations equal to or less than their corresponding FALs.

\section{A.5.2 Sources of Information}

Information to satisfy Decision I and Decision II will be generated by collecting environmental samples using grab sampling, hand auguring, and backhoe excavation or other appropriate sampling methods. These samples will be submitted to analytical laboratories meeting the quality criteria stipulated in the Industrial Sites QAPP (NNSA/NV, 2002a). Only validated data from analytical 
laboratories will be used to make DQO decisions. Sample collection and handling activities will follow standard procedures.

\section{A.5.2.1 Sample Locations}

Design of the sampling approaches for the CAU 190 CASs must ensure that the data collected are sufficient for selection of the corrective action alternatives (EPA, 2002). To meet this objective, the samples collected from each site should either be from locations that most likely contain a COC, if present (judgmental), and properly represent any contamination at the CAS. These sample locations, therefore, can be selected by means of biasing factors used in judgmental sampling (e.g., a stain, likely containing a spilled substance). A judgmental sampling design has been developed for all the CAU 190 CASs due to the presence and significance of biasing factors.

Decision I sample locations will be determined based upon the likelihood of the soil containing a COC, if present at the CAS. These locations will be selected based on field-screening techniques, biasing factors, the CSM, and existing information. Analytical suites for Decision I samples will include all COPCs identified in Table A.3-2.

Field-screening techniques may be used to select appropriate sampling locations by providing semiquantitative data that can be used to comparatively select samples to be submitted for laboratory analyses from several screening locations. Field screening may also be used for health and safety monitoring and to assist in making certain health and safety decisions. The following field-screening methods may be used to select analytical samples at CAU 190:

- Volatile organic compounds - A VOC detection instrument may be used to conduct headspace analysis at all CASs because VOCs are a common concern at the NTS and have not been ruled out based upon process knowledge.

- Walkover surface area radiological surveys - A radiological survey instrument will be used, as permitted by terrain and field conditions, to detect hot spots of radiological contamination.

- Alpha and beta/gamma radiation - A radiological survey instrument may be used to detect radiological contamination.

- Gamma emitting radionuclides - A radiological dose rate measurement instrument may be used. 
- $\quad$ Fecal coliform screening may be performed on septage.

Biasing factors also may be used to select samples to be submitted for laboratory analyses based on existing site information and site conditions discovered during the investigation. Factors also to be considered in selecting locations for analytical samples at CAU 190 are as follows:

- Documented process knowledge on source and location of release (e.g., volume of release).

- Stains: Any spot or area on the soil surface that may indicate the presence of a potentially hazardous liquid. Typically, stains indicate an organic liquid such as an oil has reached the soil and may have spread out vertically and horizontally.

- Elevated radiation: Any location identified during radiological surveys that had alpha/beta/gamma levels significantly higher than surrounding background soil.

- Geophysical anomalies: Any location identified during geophysical surveys that had results indicating surface or subsurface materials existed and were not consistent with the natural surroundings (e.g., buried metallic objects).

- Drums, containers, equipment or debris: Materials of interest that may have been used at, or added to, a location and that may have contained or come in contact with hazardous or radioactive substances at some point during their use.

- Lithology: Locations where variations in lithology (soil or rock) indicate that different conditions or materials exist.

- Preselected areas based on process knowledge of the site: Locations for which evidence such as historical photographs, experience from previous investigations, or interviewee input, exists that a release of hazardous or radioactive substances may have occurred.

- Preselected areas based on process knowledge of the contaminant(s): Locations that may reasonably have received contamination, selected on the basis of the chemical and/or physical properties of the contaminant(s) in that environmental setting.

- Previous sample results: Locations that may reasonably have been contaminated based upon the results of previous field investigations.

- Experience and data from investigations of similar sites.

- Visual indicators such as discoloration, textural discontinuities, disturbance of native soils, or any other indication of potential contamination.

- $\quad$ Presence of debris, waste, or equipment. 
- Odor.

- Physical and chemical characteristics of contaminants.

- Other biasing factors: Factors not previously defined for the CAI, but become evident once the investigation of the site is under way.

Decision II sample step-out locations will be selected based on the CSM, biasing factors, and existing data. Analytical suites will include those parameters that exceeded FALs (i.e., COCs) in prior samples. Biasing factors to support Decision II sample locations include Decision I biasing factors plus available analytical results. 


\section{A.6.0 Step 4 - Define the Boundaries of the Study}

Step 4 of the DQO process defines the target population of interest and its relevant spatial boundaries, specifies temporal and other practical constraints associated with sample/data collection, and defines the sampling units on which decisions or estimates will be made.

\section{A.6.1 Target Populations of Interest}

The population of interest to resolve Decision I ("Is any COC present in environmental media within the CAS?”) is any location within the site that is contaminated with any contaminant above a FAL. The populations of interest to resolve Decision II ("If a COC is present, is sufficient information available to evaluate potential corrective action alternatives?”) are:

- Each one of a set of locations bounding contamination in lateral and vertical directions.

- Environmental media or IDW that must be characterized for disposal.

- $\quad$ Potential remediation waste.

\section{A.6.2 Spatial Boundaries}

Spatial boundaries are the maximum lateral and vertical extent of expected contamination at each CAS, as shown in Table A.6-1. Contamination found beyond these boundaries may indicate a flaw in the CSM and may require re-evaluation of the CSM before the investigation could continue. Each CAS is considered geographically independent and intrusive activities are not intended to extend into the boundaries of neighboring CASs.

Table A.6-1

Spatial Boundaries of CAU 190 CASs

\begin{tabular}{|c|c|}
\hline Corrective Action Site & Spatial Boundaries \\
\hline \hline $11-02-01,11-02-02$, and 11-59-01 & $\begin{array}{c}\text { The footprint of each CAS plus a 100-foot (ft) lateral buffer; } \\
15 \mathrm{ft} \text { below ground surface (bgs) vertically. }\end{array}$ \\
\hline $14-23-01$ & $\begin{array}{c}\text { The footprint of the CAS plus a 4,000-ft lateral buffer; } \\
15 \mathrm{ft} \text { bgs vertically. }\end{array}$ \\
\hline
\end{tabular}




\section{A.6.3 Practical Constraints}

Practical constraints such as military activities at the NTS, weather (i.e., high winds, rain, lightning, extreme heat), utilities, threatened or endangered animal and plants, unstable or steep terrain, and/or access restrictions may affect the ability to investigate this site. The practical constraints associated with the investigation of the CAU 190 CASs are summarized in Table A.6-2.

Table A.6-2

Practical Constraints for the CAU 190 Field Investigation

\begin{tabular}{||c|c||}
\hline Corrective Action Site & Practical Constraints \\
\hline \hline $11-02-01,11-02-02$, and 11-59-01 & $\begin{array}{c}\text { Weather (i.e., high winds, rain, extreme heat) causing road } \\
\text { leading to site to be slippery; lightning forecast or lightning in the } \\
\text { area will result in immediate departure from the Tweezer Facility. } \\
\text { Military exercises; PACM around piping and foundations. }\end{array}$ \\
\hline $14-23-01$ & $\begin{array}{c}\text { Weather (i.e., high winds, rain, lightning, hot temperatures), } \\
\text { military exercises, underground utilities, and aboveground } \\
\text { utilities }\end{array}$ \\
\hline
\end{tabular}

$\mathrm{PACM}=$ Presumed asbestos-containing material

\section{A.6.4 Define the Sampling Units}

The scale of decision-making in Decision I is defined as the CAS. Any COC detected at any location within the CAS will cause the determination that the CAS is contaminated and needs further evaluation. The scale of decision-making for Decision II is defined as a contiguous area contaminated with any COC originating from the CAS. Resolution of Decision II requires this contiguous area to be bounded laterally and vertically. 


\section{A.7.0 Step 5 - Develop the Analytic Approach}

Step 5 of the DQO process specifies appropriate population parameters for making decisions, defines action levels and generates an "If ... then ... else" decision rule which involves it.

\section{A.7.1 Population Parameters}

For judgmental sampling results, the population parameter is the observed concentration of each contaminant from each individual analytical sample. Each sample result will be compared to the FALs to determine the appropriate resolution to Decision I and Decision II. For Decision I, a single sample result for any contaminant exceeding a FAL would cause a determination that a COC is present within the CAS.

The Decision II population parameter is an individual analytical result from a bounding sample. For Decision II, a single bounding sample result for any contaminant exceeding a FAL would cause a determination that the contamination is not bounded.

\section{A.7.2 Action Levels}

The PALs presented in this section are to be used for site screening purposes. They are not necessarily intended to be used as cleanup action levels or FALs. However, they are useful in screening out contaminants that are not present in sufficient concentrations to warrant further evaluation and, therefore, streamline the consideration of remedial alternatives. The RBCA process used to establish FALs is described in the Industrial Sites Project Establishment of Final Action Levels (NNSA/NSO, 2006). This process conforms with NAC Section 445A.227, which lists the requirements for sites with soil contamination (NAC, 2006). For the evaluation of corrective actions, NAC Section 445A.22705 requires the use of ASTM Method E 1739-95 to "conduct an evaluation of the site, based on the risk it poses to public health and the environment, to determine the necessary remediation standards (i.e., FALs) or to establish that corrective action is not necessary.” 
This RBCA process defines three tiers (or levels) of evaluation involving increasingly sophisticated analyses:

- Tier 1 - Sample results from source areas (highest concentrations) are compared to action levels based on generic (non-site-specific) conditions (i.e., the PALs established in the CAIP). The FALs may then be established as the Tier 1 action levels or the FALs may be calculated using a Tier 2 evaluation.

- Tier 2 - Conducted by calculating Tier 2 SSTLs using site-specific information as inputs to the same or similar methodology used to calculate Tier 1 action levels. The Tier 2 SSTLs are then compared to individual sample results from reasonable points of exposure (as opposed to the source areas as is done in Tier 1) on a point by point basis. Total TPH concentrations will not be used for risk-based decisions under Tier 2 or Tier 3. Rather, the individual chemicals of concern will be compared to the SSTLs.

- $\quad$ Tier 3 - Conducted by calculating Tier 3 SSTLs on the basis of more sophisticated risk analyses using methodologies described in Method E 1739-95 that consider site-, pathway-, and receptor-specific parameters.

The comparison of laboratory results to FALs and the evaluation of potential corrective actions will be included in the investigation report. The FALs will be defined (along with the basis for their definition) in the investigation report.

\section{A.7.2.1 Chemical PALs}

Except as noted herein, the chemical PALs are defined as the EPA Region 9 Risk-Based Preliminary Remediation Goals (PRGs) for chemical contaminants in industrial soils (EPA, 2004). Background concentrations for RCRA metals will be used instead of PRGs when natural background concentrations exceed the PRG, as is often the case with arsenic on the NTS. Background is considered the average concentration plus two standard deviations of the average concentration for sediment samples collected by the Nevada Bureau of Mines and Geology throughout the Nevada Test and Training Range (formerly the Nellis Air Force Range) (NBMG, 1998; Moore, 1999). For detected chemical COPCs without established PRGs, the protocol used by the EPA Region 9 in establishing PRGs (or similar) will be used to establish PALs. If used, this process will be documented in the investigation report. 


\section{A.7.2.2 Total Petroleum Hydrocarbon PALs}

The PAL for TPH is 100 ppm as listed in NAC 445A.2272 (NAC, 2006).

\section{A.7.2.3 Radionuclide PALs}

The PALs for radiological contaminants (other than tritium) are based on the NCRP Report No. 129 recommended screening limits for construction, commercial, industrial land-use scenarios (NCRP, 1999) scaled to 25 mrem/yr dose constraint (Murphy, 2004) and the generic guidelines for residual concentration of radionuclides in DOE Order 5400.5 (DOE, 1993). These PALs are based on the construction, commercial, and industrial land-use scenario provided in the guidance and are appropriate for the NTS based on future land-use scenarios as presented in Section A.3.2. The PAL for tritium is based on the UGTA Project limit of 400,000 pCi/L for discharge of water containing tritium (NNSA/NV, 2002b).

Solid media such as concrete and/or structures may pose a potential radiological exposure risk to site workers if contaminated. Any materials to be free-released will be done so according to the unrestricted-release criteria defined in the NV/YMP RadCon Manual (NNSA/NSO, 2004).

\section{A.7.3 Decision Rules}

The decision rules applicable to both Decision I and Decision II are:

- If COC contamination is inconsistent with the CSM, or extends beyond the spatial boundaries identified in Section A.6.2, then work will be suspended and the investigation strategy will be reconsidered; otherwise, the decision will be to continue sampling to define the extent.

- If a COC is present, is consistent with the CSM, and within spatial boundaries, then the decision will be to continue sampling to define the extent.

The decision rules for Decision I are:

- If the population parameter any COPC in the Decision I population of interest (defined in Step 4) exceeds the corresponding FAL, then that contaminant is identified as a COC, and Decision II samples will be collected; otherwise, the decision will be no further investigation is needed for that COPC in that population. 
- If a COC exists at any CAS, then a corrective action will be determined; otherwise, the decision for no further action will be necessary.

- If a waste is present that, if released, has the potential to cause the future contamination of site environmental media, then a corrective action will be determined; otherwise, the decision for no further action will be necessary.

The decision rules for Decision II are:

- If the population parameter (the observed concentration of any COC) in the Decision II population of interest (defined in Step 4) exceeds the corresponding FAL in any bounding direction, then additional samples will be collected to complete the Decision II evaluation; otherwise, the extent of the COC contamination has been defined.

- If valid analytical results are available for the waste characterization samples defined in Section A.9.0, then the decision will be that sufficient information exists to characterize the IDW for disposal, determine potential remediation waste types, and evaluate the feasibility of remediation alternatives, otherwise collect additional waste characterization samples. 


\section{A.8.0 Step 6 - Specify Performance or Acceptance Criteria}

Step 6 of the DQO process defines the decision hypotheses, specifies controls against false rejection and false acceptance decision errors, examines consequences of making incorrect decisions from the test, and places acceptable limits on the likelihood of making decision errors.

\section{A.8.1 Decision Hypotheses}

The baseline condition (i.e., null hypothesis) and alternative condition for Decision I are:

- $\quad$ Baseline condition - A COC is present.

- Alternative condition - A COC is not present.

The baseline condition (i.e., null hypothesis) and alternative condition for Decision II are as follows:

- Baseline condition - The extent of a COC has not been defined.

- Alternative condition - The extent of a COC has been defined.

Decisions and/or criteria have false negative or false positive errors associated with their determination. The impact of these decision errors and the methods that will be used to control these errors are discussed in the following subsections. In general terms, confidence in DQO decisions based on judgmental sampling results will be established qualitatively by:

- The development of and concurrence of CSMs (based on process knowledge) by stakeholder participants during the DQO process.

- $\quad$ Testing the validity of CSMs based on investigation results.

- Evaluating the quality of the data based on DQI parameters.

\section{A.8.2 False Negative Decision Error}

The false negative decision error would mean deciding that a COC is not present when it actually is (Decision I), or that the extent of a COC has been defined when it has not (Decision II). In both cases, the potential consequence is an increased risk to human health and environment. 
In judgmental sampling, the selection of the number and location of samples is based on knowledge of the feature or condition under investigation and on professional judgment (EPA, 2002). Judgmental sampling conclusions about the target population depend upon the validity and accuracy of professional judgment.

The false negative decision error (where consequences are more severe) for judgmental sampling designs is controlled by meeting these criteria:

- For Decision I, having a high degree of confidence that the sample locations selected will identify COCs if present anywhere within the CAS. For Decision II, having a high degree of confidence that the sample locations selected will identify the extent of COCs.

- Having a high degree of confidence that analyses conducted will be sufficient to detect any COCs present in the samples.

- Having a high degree of confidence that the dataset is of sufficient quality and completeness.

To satisfy the first criterion, Decision I samples must be collected in areas most likely to be contaminated by COCs (supplemented by random samples where appropriate). Decision II samples must be collected in areas that represent the lateral and vertical extent of contamination (above FALs). Characteristics that must be considered to control decision errors for the first criterion are as follows:

- $\quad$ Source and location of release

- Chemical nature and fate properties

- Physical transport pathways and properties

- Hydrologic drivers

These characteristics were considered during the development of the CSMs and selection of sampling locations. The field-screening methods and biasing factors listed in Section A.5.2.1 will be used to further ensure that appropriate sampling locations are selected to meet these criteria. Radiological survey instruments and field-screening equipment will be calibrated and checked in accordance with the manufacturer's instructions and approved procedures. The investigation report will present an assessment on the DQI of representativeness that samples were collected from those locations that best represent the populations of interest as defined in Section A.6.1. 
To satisfy the second criterion, Decision I samples will be analyzed for the chemical and radiological parameters listed in Section 3.2. Decision II samples will be analyzed for those chemical and radiological parameters that identified unbounded COCs. The DQI of sensitivity will be assessed for all analytical results to ensure that all sample analyses had measurement sensitivities (detection limits) that were less than or equal to the corresponding FALs. If this criterion is not achieved, the affected data will be assessed (for usability and potential impacts on meeting site characterization objectives) in the investigation report.

To satisfy the third criterion, the entire dataset, as well as individual sample results, will be assessed against the DQIs of precision, accuracy, comparability, and completeness as defined in the Industrial Sites QAPP (NNSA/NV, 2002a) and in Section 6.2.2. The DQIs of precision and accuracy will be used to assess overall analytical method performance, as well as to assess the need to potentially “flag” (qualify) individual contaminant results, when corresponding QC sample results are not within the established control limits. Data qualified as estimated for reasons of precision or accuracy may be considered to meet the constituent performance criteria based on an assessment of the data. The DQI for completeness will be assessed to ensure that all identified DQO data needs have been met. The DQI of comparability will be assessed to ensure that all analytical methods used are equivalent to standard EPA methods so that results will be comparable to regulatory action levels that have been established using those procedures. Strict adherence to established procedures and QA/QC protocol protects against false negatives. Site-specific DQIs are discussed in more detail in Section 6.2.2.

To provide information for the assessment of the DQIs of precision and accuracy, the following QC samples will be collected as required by the Industrial Sites QAPP (NNSA/NV, 2002a):

- $\quad$ Field duplicates (1 per CAS)

- $\quad$ Laboratory QC samples (1 per CAS)

\section{A.8.3 False Positive Decision Error}

The false positive decision error would mean deciding that a COC is present when it is not, or a COC is unbounded when it is not, resulting in increased costs for unnecessary sampling and analysis.

False positive results are typically attributed to laboratory and/or sampling/handling errors that could cause cross contamination. To control against cross contamination, decontamination of sampling 
equipment will be conducted according to established and approved procedures and only clean sample containers will be used. To determine whether a false positive analytical result may have occurred, the following QC samples will be collected as required by the Industrial Sites QAPP (NNSA/NV, 2002a):

- Trip blanks (1 per sample cooler containing VOC environmental samples)

- Equipment blanks (1 at CAS 11-59-01)

- Source blanks (1 per source lot per sampling event)

- Field blanks (minimum of 1 per CAS, additional if field conditions change) 


\section{A.9.0 Step 7 - Develop the Plan for Obtaining Data}

Step 7 of the DQO process selects and documents a design that will yield data that will best achieve performance or acceptance criteria. A judgmental sampling scheme will be implemented to select sample locations and evaluate analytical results for CAU 190. Sections A.9.1 and A.9.2 contain general information about collecting Decision I and Decision II samples under a judgmental sampling design, while the subsequent sections provide CAS-specific sampling activities, including proposed sample locations.

\section{A.9.1 Judgmental Sampling}

A judgmental sampling design will be implemented for all the CASs in CAU 190. Because individual sample results, rather than an average concentration, will be used to compare to FALs at the CASs undergoing judgmental sampling, statistical methods to generate site characteristics will not be used. Adequate representativeness of the entire target population may not be a requirement to developing a sampling design. If good prior information is available on the target site of interest, then the sampling may be designed to collect samples only from areas known to have the highest concentration levels on the target site. If the observed concentrations from these samples are below the action level, then a decision can be made that the site contains safe levels of the contaminant without the samples being truly representative of the entire area (EPA, 2006).

All sample locations will be selected to satisfy the DQI of representativeness in that samples collected from selected locations will best represent the populations of interest as defined in Section A.6.1. To meet this criterion for judgmentally sampled sites, a biased sampling strategy will be used for Decision I samples to target areas with the highest potential for contamination, if it is present anywhere in the CAS. Sample locations will be determined based on process knowledge, previously acquired data, or the field-screening and biasing factors listed in Section A.5.2.1. If biasing factors are present in soils below locations where Decision I samples were removed, additional Decision I soil samples will be collected at depth intervals selected by the SS based on biasing factors to a depth where the biasing factors are no longer present. The SS has the discretion to modify the judgmental sample locations, but only if the modified locations meet the decision needs and criteria stipulated in this DQO. 


\section{A.9.2 Decision II Sampling}

To meet the DQI of representativeness for Decision II samples (that Decision II sample locations represent the population of interest as defined in Section A.6.1), judgmental sampling locations at each CAS will be selected based on the outer boundary sample locations where COCs were detected, the CSM, and other field-screening and biasing factors listed in Section A.5.2. In general, sample locations will be arranged in a triangular pattern around the Decision I location or area at distances based on site conditions, process knowledge, and biasing factors. If COCs extend beyond the initial step-outs, Decision II samples will be collected from incremental step-outs. Initial step-outs will be at least as deep as the vertical extent of contamination defined at the Decision I location and the depth of the incremental step-outs will be based on the deepest contamination observed at all locations. A clean sample (i.e., COCs less than FALs) collected from each step-out direction (lateral or vertical) will define extent of contamination in that direction. The number, location, and spacing of step-outs may be modified by the SS, as warranted by site conditions.

\section{A.9.3 Corrective Action Site 11-02-01, Underground Centrifuge}

No soil staining was observed at this CAS during recent site visits. The centrifuge was not designed to release contaminants and there is no evidence (staining, historical documents, interviews) that the centrifuge has ever released contaminants into the environment; therefore, samples will not be collected beneath or around the centrifuge. However, Decision I soil samples will be collected from the surface soil beneath both ends of the hydraulic lines laying on the ground. These samples will be analyzed for TPH only unless biasing factors indicate contamination. If the TPH concentration is elevated above 75 ppm, the soil samples will also be analyzed for VOCs, SVOCs, and PCBs.

As a best management practice and to prevent future spread of COCs, the two hydraulic lines will be disconnected from the centrifuge motor, drained of hydraulic oil (if present), and disposed. The lead bricks inside the centrifuge will also be removed for disposal or recycling. The ladder bolted to the centrifuge will be removed, and left on the centrifuge floor, so the lid hatch can be closed.

\section{A.9.4 Corrective Action Site 11-02-02, Drain Lines and Outfall}

During Decision I sampling, soil samples will be collected from the surface soil at the outfall. One from 0 to 6 in. and one from 6 in. to $1 \mathrm{ft}$ bgs. This sample location at the pipe outfall was selected 
because it is the most likely location to contain COCs, if present at this CAS. Also this location is within the surface drainage channel based on the preferential pathway for surface runoff as depicted in the CSM.

The 3-in., schedule-40, black steel pipe will not be surveyed with the video mole due to the small pipe diameter and because the pipe is not expected to be breached.

Any source material (liquid, scale, or sludge) found inside the cooling tower will be sampled and analyzed for RCRA metals. If the decision is made to remove the cooling tower, then the water storage tanks will also be removed for disposal as a best management practice and samples will be collected from the pipe insulation around the cooling tower and analyzed for asbestos.

\section{A.9.5 Corrective Action Site 11-59-01, Tweezer Facility Septic System}

A minimum of two subsurface samples will be collected from below piping inlets/outlets to the septic tank. These samples will be collected from below the piping and analyzed to determine whether COPCs are present in subsurface soil resulting from effluent that may have leaked at the connections. A minimum of two subsurface samples will be collected from below the ends of the septic tank at the inlet and outlet ends. These samples will be analyzed to determine whether COPCs are present in subsurface soils resulting from effluent that may have leaked from the septic tank. If a distribution box is present, samples will also be collected at the same locations as the septic tank.

A minimum of 20 additional subsurface soil samples will be collected at 10 locations within the leachfield. Locations will be selected from the proximal and distal ends of the leachfield and several locations in between. These samples will be collected from below leachfield distribution piping at the native soil/leachfield material contact and approximately $2.5 \mathrm{ft}$ below that contact. These samples will be analyzed to determine whether COPCs were present in the effluent.

A video-mole survey will be conducted on subsurface piping that is accessible and determined to be practical, including piping from all potential source drains and collection system connecting to the septic tank and leachfield. The only practical access point is located at the septic tank due to restrictions of using a backhoe in the vicinity of the building foundation. This restriction may limit 
the video survey coverage from the septic tank to the source building. This survey will be performed to verify the integrity of the piping.

An excavation will be conducted to gain access to the septic tank (and distribution box, if present) for inspection and sampling, as needed. The septic tank (and distribution box, if present) will be opened and if residual material is present, a sample will be collected of all phases present (liquid, sludge, solid) for waste characterization purposes.

Surface debris (chairs, trash cans) are currently located within and in the vicinity of the CASs. As a best management practice, the debris will be removed from the CASs. The following housekeeping activities will be conducted at this CAS:

- If there is residual material identified inside any of the debris (trash cans), that media will be sampled for waste management purposes. If no residual material is present, the debris will be disposed of as solid or salvageable waste.

- Verification samples will be collected from the underlying soil if the debris is suspected of contaminating the soil. The removal of debris will be documented in the FADL.

- The debris will be surveyed for potential radiological contamination and a copy of the results will be maintained in the project files. Results of the survey will be reported in the CADD and/or closure report.

- Photographs will be taken to document the condition of the site before and after the removal of the debris.

- $\quad$ The proper waste documentation will be completed and included in the CADD.

\section{A.9.6 Corrective Action Site 14-23-01, LTU-6 Test Area}

The LTU-6 Test Area is in the northern part of Area 14 near the Mine Mountain Road and Mid Valley Road junction. The site is the location of a former HEST area and the LTU-6 Test Area. There is potential radiological and chemical contamination of the soil from activities associated with the testing that was conducted in the area. There was no staining observed in or around the trailer bunkers or the generator sheds during a recent site visit (July 2006), and the decision was made during the DQO meeting to move the CAS boundary to the testing area. 
A radiological walkover survey was performed on a portion of the site on September 1, 2006, and is discussed in Section A.2.0. The radiological survey identified points of elevated radiation that may be associated with metal debris fragments found on the ground. Because metal debris were easily located by visual inspection, a geophysical survey of the site was not conducted. These data and historical data were used to bias the sampling locations.

During Decision I sampling, the following features will be sampled and are shown in Figure A.9-1:

- At four anomalous areas of higher radioactivity as identified by the radiological survey. One surface sample will be collected and a deeper sample ( $1 \mathrm{ft}$ bgs) will be collected if radiological screening indicates elevated readings.

- At four surface soil locations identified by the fragment location map (Holmes and Narver, 1986) showing the locations of former collected debris. If radiological screening indicates elevated readings, a sample from beneath this horizon may be collected during Decision I sampling.

- Additional locations may be sampled beneath debris fragments based upon the judgment of the SS, if radiological screening indicates elevated readings, or other biasing factors are present. 


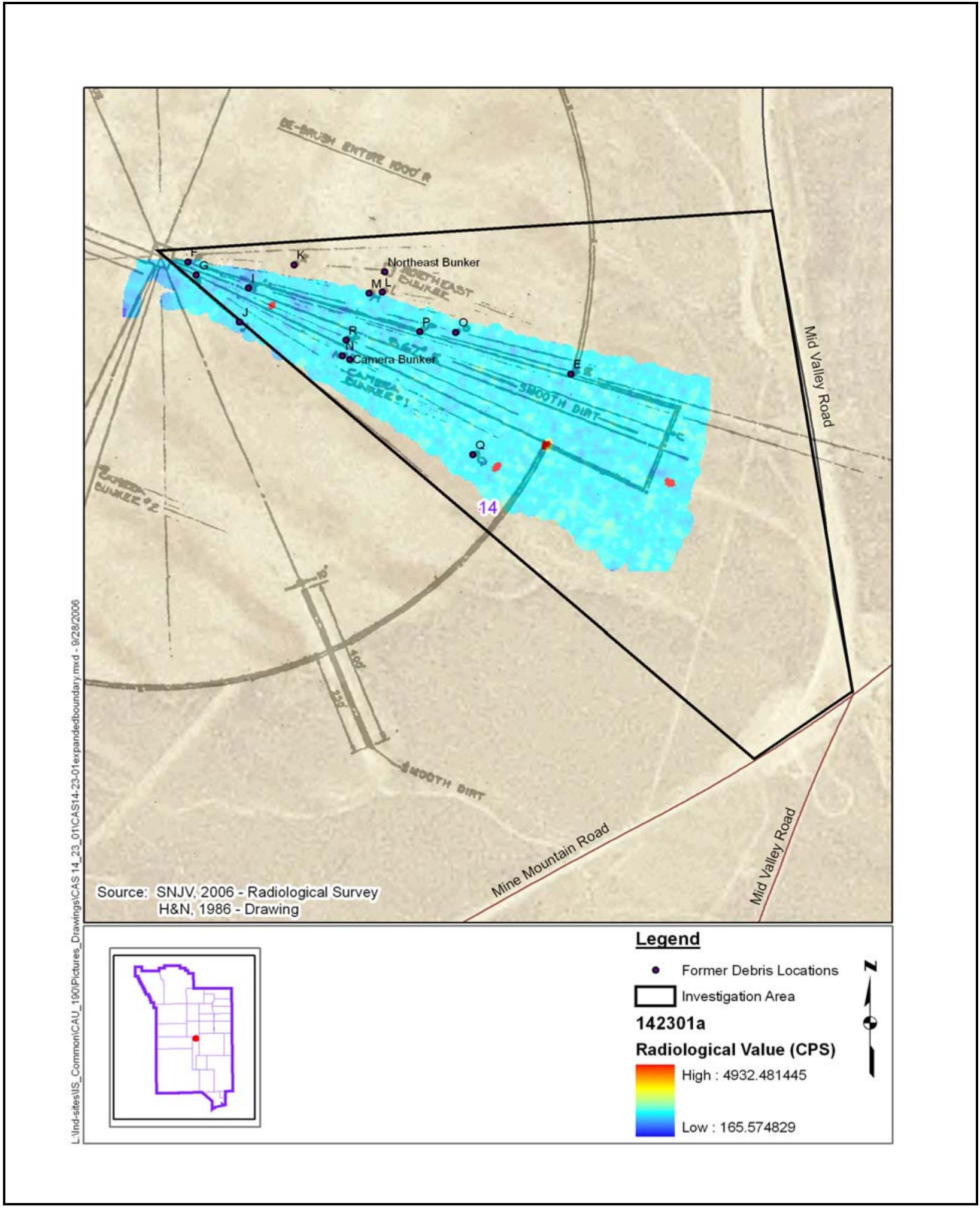

Figure A.9-1

\section{Corrective Action Site 14-23-01 Features}




\section{A.10.0 References}

Cole, J.C., and P.H. Cashman. 1997. Geologic Map of the Mine Mountain Area, Nevada Test Site, Southern Nevada. U.S. Department of Energy, Nevada Operations Office.

Desert Research Institute. 1988. CERCLA Preliminary Assessment of DOE's Nevada Operations Office Nuclear Weapons Testing Areas. April. Las Vegas, NV.

DOE, see U.S. Department of Energy.

DOE/NV, see U.S. Department of Energy, Nevada Operations Office.

DRI, see Desert Research Institute.

EPA, see U.S. Environmental Protection Agency.

Holmes \& Narver, Inc. 1975. Aerial photograph entitled “Area 11 Tweezer Facilities,” 18 April. Mercury, NV: BN Records and Archive Center.

Holmes \& Narver, Inc. 1986. Nevada Test Site - Area 14 - LLNL Rocket Motor Explosion Test Site and GZ Layout Plan and Notes. U.S. Department of Energy, Nevada Operations Office. 22 January.

Moore, J., Science Applications International Corporation. 1999. Memorandum to M Todd (SAIC) entitled, “Background Concentrations for NTS and TTR Soil Samples,” 3 February. Las Vegas, NV: IT Corporation.

Murphy, T., Bureau of Federal Facilities. 2004. Letter to R. Bangerter (NNSA/NSO) entitled, "Review of Industrial Sites Project Document Guidance for Calculating Industrial Sites Project Remediation Goals for Radionuclides in Soil Using the Residual Radiation (RESRAD) Computer Code,” 19 November. Las Vegas, NV.

NAC, see Nevada Administrative Code.

NBMG, see Nevada Bureau of Mines and Geology.

NCRP, see National Council on Radiation Protection and Measurements.

NNSA/NSO, see U.S. Department of Energy, National Nuclear Security Administration Nevada Site Office.

NNSA/NV, see U.S. Department of Energy, National Nuclear Security Administration Nevada Operations Office. 
National Council on Radiation Protection and Measurements. 1999. Recommended Screening Limits for Contaminated Surface Soil and Review of Factors Relevant to Site-Specific Studies/National Council on Radiation Protection and Measurements, NCRP Report No. 129. Bethesda, MD.

Nevada Administrative Code. 2006. NAC 445A, "Water Controls.” Carson City, NV. As accessed at http://www.leg.state.nv.us/nac on 15 June.

Nevada Bureau of Mines and Geology. 1998. Mineral and Energy Resource Assessment of the Nellis Air Force Range, Open-File Report 98-1. Reno, NV.

REECo, see Reynolds Electrical \& Engineering Co., Inc.

Reynolds Electrical \& Engineering Co., Inc. 1962. Engineering drawing 11-2-M1 Entitled, “Structure 11-2 Equipment Building Piping and Plumbing Plan,” 24 March. Mercury, NV: Archives and Records Center.

Reynolds Electrical \& Engineering Co., Inc. 1991. Nevada Test Site Inventory of Inactive and Abandoned Facilities and Waste Sites, Areas 11-15, Volume 3. April. U.S. Department of Energy.

Shaw, see Shaw Environmental, Inc.

SNJV, see Stoller-Navarro Joint Venture.

Shaw Environmental, Inc. 2003. Digital Photographs for CAU 190, CAS 11-02-01. Las Vegas, NV.

Shott, G.J., V. Yucel, M.J. Sully, L.E. Barker, S.E. Rawlinson, and B.A. Moore. 1997. Performance Assessment/Composite Analysis for the Area 3 Radioactive Waste Management Site at the Nevada Test Site, Nye County, Nevada, Rev. 2.0. Las Vegas, NV.

Stoller-Navarro Joint Venture. 2006. Radiological Land Area Survey. Las Vegas, NV.

U.S. Department of Energy. 1993. Radiation Protection of the Public and the Environment, DOE Order 5400.5, chg.2. Washington, DC: U.S. Government Printing Office.

U.S. Department of Energy, National Nuclear Security Administration Nevada Operations Office. 2002a. Industrial Sites Quality Assurance Project Plan, Nevada Test Site, Nevada, Rev. 3, DOE/NV--372. Las Vegas, NV.

U.S. Department of Energy, National Nuclear Security Administration Nevada Operations Office. 2002b. Underground Test Area Project Waste Management Plan, DOE/NV--343-Rev. 2. Las Vegas, NV. 
U.S. Department of Energy, National Nuclear Security Administration Nevada Site Office. 2004. NV/YMP Radiological Control Manual, Rev. 5, DOE/NV/11718-079. Prepared by Bechtel Nevada. Las Vegas, NV.

U.S. Department of Energy, National Nuclear Security Administration Nevada Site Office. 2006. Industrial Sites Project Establishment of Final Action Levels. February. Las Vegas, NV.

U.S. Department of Energy, Nevada Operations Office. 1992. Remedial Investigation and Feasibility Study for the Plutonium Contaminated Soils at Nevada Test Site, Nellis Air Force Range and Tonopah Test Range. April. Las Vegas, NV.

U.S. Department of Energy, Nevada Operations Office. 1996. Final Environmental Impact Statement for the Nevada Test Site and Off-Site Locations in the State of Nevada, DOE/EIS 0243. Las Vegas, NV.

U.S. Department of Energy, Nevada Operations Office. 1998. Nevada Test Site Resource Management Plan, DOE/NV-518. Las Vegas, NV.

U.S. Environmental Protection Agency. 2002. Guidance for Quality Assurance Project Plans, EPA QA/G5. Washington, DC.

U.S. Environmental Protection Agency. 2004. Region 9 Preliminary Remediation Goals (PRGs). As accessed at http://www.epa.gov/region09/waste/sfund/prg/index.htm on 16 May 2006. Prepared by S.J. Smucker. San Francisco, CA.

U.S. Environmental Protection Agency. 2006. EPA Guidance on Systematic Planning using the Data Quality Objectives Process, EPA QA/G-4. Washington, DC.

Winograd, I.J., and R.A. Young. 1965. Hydrologic Maps of the Nevada Test Site and Vicinity. U.S. Geological Survey.

Winograd, I.J., and W. Thordarson. 1975. Hydrology and Hydrochemical Framework, South-Central Great Basin, Nevada-California, with Special Reference to the Nevada Test Site, USGS Professional Paper 712-C. Denver, CO. 
Appendix B

Project Organization 


\section{B.1.0 Project Organization}

The NNSA/NSO Federal Sub-Project Director is Kevin Cabble. He can be contacted at (702) 295-5000. The NNSA/NSO TM for CAU 190 is Sabine Curtis. She can be contacted at (702) 295-0542.

The identification of the project Health and Safety Officer and the Quality Assurance Officer can be found in the appropriate plan. However, personnel are subject to change and it is suggested that the appropriate DOE Project Manager be contacted for further information. The TM will be identified in the FFACO Monthly Activity Report before the start of field activities. 


\title{
Appendix C
}

\section{Nevada Division of Environmental Protection Comments}

\author{
(1 Page)
}


November 2, 2006

John B. Jones

Acting Environmental Restoration Federal Project Director

Environmental Restoration Project

National Nuclear Security Administration

Nevada Site Office

P. O. Box 98518

Las Vegas, NV 89193-8518

RE: Review of the draft Corrective Action Investigation Plan (CAIP) Corrective Action Unit (CAU) 190: Contaminated Waste Sites Federal Facility Agreement and Consent Order

Dear Mr. Jones,

The Nevada Division of Environmental Protection, Bureau of Federal Facilities (NDEP) staff has received and reviewed the draft Corrective Action Investigation Plan (CAIP) for Corrective Action Unit (CAU) 190: Contaminated Waste Sites. NDEP's review of this document did not indicate any deficiencies.

Address any questions regarding this matter to Jeff MacDougall, Ph.D. at (702) 486-2850 ext 233 , or me at (702) $486-2850$ ext 229.

Sincerely,

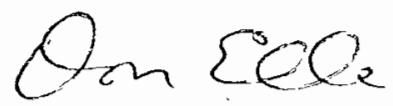

Don Elle, Ph.D.

Supervisor

Bureau of Federal Facilities

DRE/JJM/jjm

cc: $\quad$ Federal Project Director, WMP, NNSANSO

FFACO Group, SNJV, Las Vegas, NV

Tiffany Lantow, DTRA/CXT1, M/S 645, Mercury, NV

Kevin Cabble, ERP, NNSA/NSO, Las Vegas, NV

Pete Sanders, ERP, NNSA/NSO, Las Vegas, NV

Sabine Curtis, ERP, NNSA/NSO, Las Vegas, NV

Jeff Smith, NSTec, Las Vegas, NV

Robert Boehlecke, SNJV, Las Vegas, NV 


\section{Library Distribution List}

\section{$\underline{\text { Copies }}$}

U.S. Department of Energy

National Nuclear Security Administration

Nevada Site Office

Technical Library

P.O. Box 98518, M/S 505

Las Vegas, NV 89193-8518

U.S. Department of Energy

Office of Scientific and Technical Information

P.O. Box 62

Oak Ridge, TN 37831-0062

Southern Nevada Public Reading Facility

c/o Nuclear Testing Archive

P.O. Box 98521, M/S 400

Las Vegas, NV 89193-8521

Manager, Northern Nevada FFACO

Public Reading Facility

c/o Nevada State Library \& Archives

100 N Stewart Street

Carson City, NV 89701-4285
1 (Uncontrolled, electronic copy)

1 (Uncontrolled, electronic copy)

2 (Uncontrolled, electronic copies)

1 (Uncontrolled, electronic copy) 